\title{
Early ontogeny, anomalous growth, and healed injuries in the Silurian nautiloid Ophioceras Barrande - Implications for hatching and the autecology of the Tarphycerida
}

\author{
VOJTĚCH TUREK \& ŠTĚPÁN MANDA
}

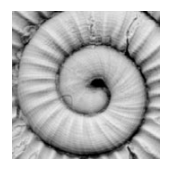

\begin{abstract}
Our study of the early ontogeny of the Silurian Ophioceras has led to the revision of the current concept that many juvenile tarphycerids possessed a coiled conch upon hatching and thus resembled adults in habit as is in extant Nautilus. In fact, there is no evidence that any Early Palaeozoic coiled nautiloid possessed an embryonic conch exceeding half a whorl. A change in conch coiling, occasionally accentuated by a dorsolateral groove analogous to the nepionic constriction and the appearance of conspicuous growth anomalies indicate that, after hatching, Ophioceras possessed a cap-shaped, slightly curved conch, usually approximately a quarter whorl long. A hatchling thus differed substantially from the likely nektonic late juveniles with coiled conchs and their obliquely oriented aperture as in Nautilus. A relatively large first phragmocone chamber and very short body chamber possibly resulted in positive buoyancy and a planktonic habit of hatchlings. The embryonic conch size is highly variable and the height of the first chamber varies between 1.2-2.6 $\mathrm{mm}$. Changes in sculpture across the embryonic/juvenile conch boundary are sometimes gradual, but frequently, hatching is manifested by an abrupt increase in growth line spacing and the appearance of longitudinal ridges. The cicatrix is here documented in the Tarphycerida for the first time. A distinct chamber length decrease, commonly present close to the end of the first whorl, is not linked with hatching. Anomalous conch structures in Ophioceras including healed injuries, atypical shapes of ribs, atypical courses of septa and pits occurring in late juvenile growth stages are described in the light of the autecology of Ophioceras and the determination of early post-embryonic growth anomalies. - Key words: Nautiloidea, Tarphycerida, Silurian, early ontogeny, hatching time, septal spacing, anomalous growth.
\end{abstract}

TUREK, V. \& MANDA, Š. 2016. Early ontogeny, anomalous growth, and healed injuries in the Silurian nautiloid Ophioceras Barrande - Implications for hatching and the autecology of the Tarphycerida. Bulletin of Geosciences 91(2), 331-366 (18 figures, 4 tables). Czech Geological Survey, Prague. ISSN 1214-1119. Manuscript received November 27, 2015; accepted in revised form May 4, 2016; published online June 29, 2016; issued June 30, 2016.

Vojtěch Turek, Department of Palaeontology, National Museum, Václavské náměstí 68, 11579 Praha 1, Czech Republic; vojtech_turek@nm.cz• Stěpán Manda, Division of Regional Geology of Sedimentary Formations, Czech Geological Survey, PO Box 85, 11821 Praha 1, Czech Republic; stepan.manda@geology.cz.

Dispersion pattern, diversification and abundance of cephalopods through time are closely linked with the evolution of early ontogenetic strategies. Egg size has been linked with the amount of eggs per mother animal, incubation time, degree of development, habit and the mode of life of hatchlings (Landman et al. 1983, De Baets et al. 2015). The timing of hatching and the degree of hatchling development is inferred in fossil cephalopods from the morphology of their conchs. Assessment of the boundary between embryonic and post-embryonic growth stages of cephalopod conchs is nevertheless difficult, since the number of conchs preserving the embryonic part is still limited and their intraspecific variability in Early Palaeozoic Nautiloidea is high.
Palaeozoic nautiloids had various modes of life (e.g., Flower 1957, Teichert 1988, Wastermann 1998, Barskov et al. 2008) but Mesozoic and Cenozoic nautiloids (Nautilida) comprise only actively swimming animals with coiled conchs, which hardly changed their mode of life during ontogeny (e.g., Chirat \& Rioult 1998). Based on a change in septal spacing, a similar habit was supposed for tarphycerids (Schindewolf 1934, Stumbur 1959, Shimanski \& Zhuravleva 1961). Although Tarphycerida and Nautilida diverged from a common ancestor not later than in the earliest Ordovician (e.g., Dzik 1984, Kröger \& Landing 2008), both groups evolved largely convergent conch morphologies. The coiled nautiloid conch morphology appeared for the first time within tarphycerids (Teichert 
1988). The great similarity in early ontogenetic development between Ordovician Tarphycerida and post-Triassic Nautilida is striking. Holland (1985) suggested that hatchlings of Ophioceras Barrande, 1865 were probably planktonic, because the early conch of Ophioceras resembles that of some ammonoids. Westermann (1998) also adopted this concept, but neither author has provided any evidence.

Here, we focus on morphology and variability of the embryonic and early juvenile conchs of Ophioceras Barrande, 1865, a widespread, morphologically striking and evolutionary youngest Silurian tarphycerid (Fig. 1). Ophioceras belongs to the family Ophioceratidae Hyatt, 1894. On the one hand, it possesses the characteristic tarphycerid conch morphology with a tightly coiled, coarsely ribbed, planispiral, evolute conch and an annular elevation with a single ventrally located retractor muscle scar, but on the other hand, it accommodated morphological novelties including the gradual reduction of siphuncle diameter and thin connecting rings. Twelve species formerly described from Europe, North America and China were reduced to two clearly distinguishable species, namely $O$. simplex (Barrande, 1855) and $O$. rudens Barrande, 1865 (Stridsberg \& Turek 1997). The more robust $O$. simplex is a species with a relatively long stratigraphic range of about $13 \mathrm{~m} . \mathrm{y}$. from the early Wenlock (Sheinwoodian) to the uppermost Prídolí. O. rudens possesses a slender, more gradually expanding conch with a wider siphuncle, thus resembling Ordovician tarphycerids rather than $O$. simplex. $O$. rudens appeared in the early Homerian and disappeared in the early Ludfordian (Stridsberg \& Turek 1997).

An extensive collection of 190 well-preserved specimens of Ophioceras (184 from Bohemia and 6 from Gotland) permits the examination of early conch morphology and its variability in more detail than in other tarphycerids. Our study of early growth stages of Ophioceras suggests that published statements concerning early ontogenetic development of tarphycerids, especially identification of hatching time in tarphycerids, require revision. Conclusions derived from conch morphology are supported by the well-preserved specimens of Ophioceras including palaeogeographic dispersion patterns, ontogeny and absence of freshly hatched specimens in the fossil record. Our material illustrates intraspecific variability of embryonic conchs, which has never been documented from any other Palaeozoic nautiloid.

\section{Material and methods}

Material from Bohemia. - From 566 Ophioceras specimens at our disposal from Bohemia, 22 showed pits on internal moulds, and 184 display well-preserved early whorls (163 O. simplex and 21 O. rudens). These 206 specimens and a few others with healed damage were selected and used for study. The majority of the studied specimens come from Barrande's collection.

$O$. rudens comes from the localities Praha-Jinonice, $\mathrm{Na}$ břekvici Section (Butowitz according Barrande; Ludlow, Gorstian, Neodiversograptus nilssoni Zone; Kříž 1992), the road-cut near Hemrovy Rocks near Praha-Jinonice (N. nilssoni Zone), and Praha-Malá Chuchle, Vyskočilka Section (Wiskočilka according Barrande; Ludlow, Gorstian, Lobograptus scanicus Zone; Manda \& Kříž 2007).

Our material of $O$. simplex was discovered at Beroun-Dlouhá hora (Dlauha hora; Ludfordian), Beroun-Kosov (Kosov; Ludfordian), Zadní Kopanina (Hinter Kopanina; Ludfordian-latest Přídolí), Karlštejn (Karlstein; middle-latest Př́idolí), Praha-Lochkov (Lochkow; Ludfordian-middle Přídolí), Praha-Kosoř (Kosorz; Ludfordian-middle Přídolí), Praha-Velká Chuchle (Gross Kuchel; Ludfordian), and Praha-Dvorce (Dvoretz; late Ludfordian-latest Přídolí). In some specimens, the locality is not specified. Precise data concerning localities are frequently missing in old collections. The locality is often identified by the name of the nearest village. Because selected sections in classical localities have been revised and studied bed by bed, sediment characters and mode of preservation of fossils frequently allows identifying both locality and age of these specimens, (e.g., Kříž et al. 1986, Kř́iž 1992). Additional specimens were collected in the past 60 years by J. Bouška, R. Růžička, R. Horný, J. Kříž, L. Zedník, A. Čížek and the authors. The material obtained during detailed stratigraphic studies of many sections permits evaluation of stratigraphic range and distribution/abundance of Ophioceras in various biofacies. All specimens used for this study are housed in the National Museum, Prague, Czech Republic (prefix NM-L) and the Czech Geological Survey (prefix SM).

Material from Gotland. - From over 200 specimens of $O p$ hioceras available from the last taxonomic revision (Stridsberg \& Turek 1997), only a few show a well-preserved initial part of the conch. Three specimens of $O$. simplex [= "O. reticulatum" (Angelin) in Angelin \& Lindström (1880)] and four specimens of $O$. rudens [= "O. rota" (Lindström, 1890)] were used for this study. They come from the collection of N.P. Angelin and G. Lindström (prefix Mo, Natural History Museum, Stockholm). The exact collection sites are usually uncertain. Their mode of preservation permits the identification of both lithostratigraphical unit and their age, at least to stage-level. The stratigraphic range of the genus in Gotland is from early Wenlock to latest Ludlow. The best-preserved specimens restudied here come from Samsugn (Wenlock), Tänglings hällar (Ludlow), Sandarve kulle (Ludlow) and Mannagärde (Ludlow) (for a detailed description of these localities see Laufeld 1974, Stridsberg 1985 and Stridsberg \& Turek 1997). 

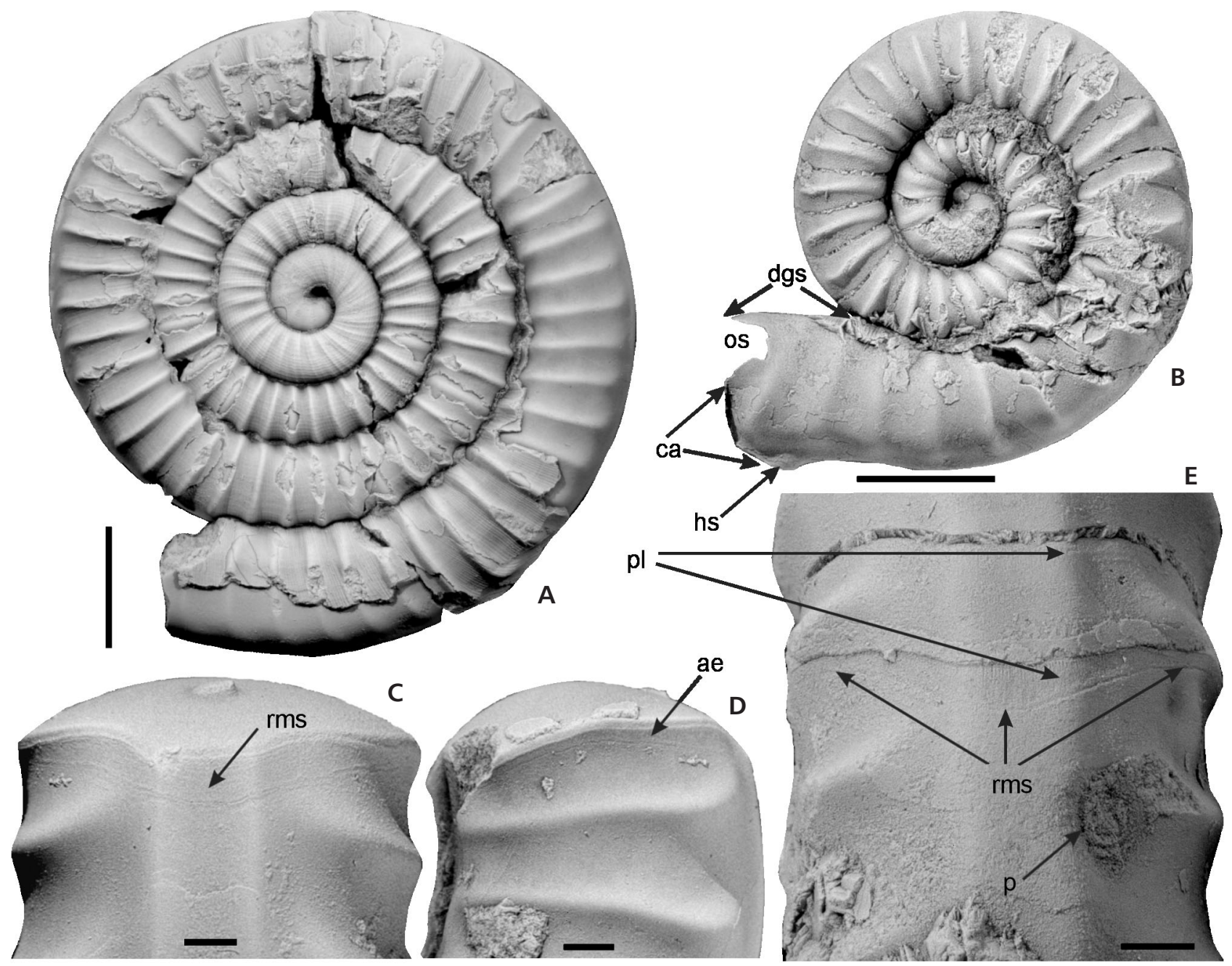

Figure 1. General morphology of Ophioceras Barrande. Illustrated specimens come from the Silurian of Bohemia. • A - O. rudens Barrande, 1865; NM-L 9102, paralectotype, lateral view; incomplete specimen with missing adapertural part of the conch; Ludlow, Homerian, N. nilssoni Zone; Praha-Butovice, Na břekvici section. • B-E - O. simplex (Barrande, 1855); B, E - NM-L 7840, holotype by monotypy; late Ludlow or earlier Přídolí; Praha-Lochkov. B - lateral view, complete internal mould with divergent later growth stages (dgs), contracted aperture (ca) possessing distinct ocular sinus (os) and deep hyponomic sinus (hs). E - ventral view, detail of adapical part of body chamber showing a single lobe of retractor muscle (rms) and imprints of palliovisceral ligaments near septum (pl); a pit filled with sediment situated ventrolaterally (p). C, D - NM-L 7841, ventral and lateral views; late Ludlow or earlier Př́idolí; vicinity of Prague; internal mould of adapical part of body chamber showing annular elevation (ae); retractor muscle scar (rms) forms a single ventral lobe (C), toward dorsal side annular elevation becomes narrower (D). Scale bars equal $5 \mathrm{~mm}(\mathrm{~A}, \mathrm{~B})$ and $1 \mathrm{~mm}(\mathrm{C}-\mathrm{E})$.

Methods. - The study of the initial growth stages of these conchs required either careful mechanical preparation of the umbilical region or the production of median sections. Specimens were photographed with an Olympus DP72 camera and a Keyence digital microscope VHX-2000E. The specimens were whitened with ammonium chloride before photographing. Images of polished sections and thin sections were captured using a digital scanner; for documentation of some morphological details, a Hitachi S-3700N scanning electron microscope was used.

Terminology. - The terminology used herein is mostly adopted from Stridsberg \& Turek (1997). For describing ontogeny, the following shell growth stages are used: em- bryonic, early juvenile (through the end of the first whorl), late juvenile (beginning with the second whorl), premature (uncoiled part of the shell) and mature (with modified aperture). Morphological terms and measurements are explained in Figs 1 and 2. The length of the first chamber is measured as a line segment along the axis of the conch. To quantify the expansion rate of the initial whorl, the ratio $e r=w h 2 / w h 1$ is used (Fig. 2); the ratio between siphuncle thickness and the dorsoventral conch diameter is expressed by the $d s / d v$ ratio ( $d s=$ siphuncle diameter, $d v=$ dorsoventral diameter measured in median plane; due to very shallow imprint zone, $d v$ is almost equal to $w h$ ).

Historically, the term "protoconch" was frequently used for the most apical part of the phragmocone, separated 


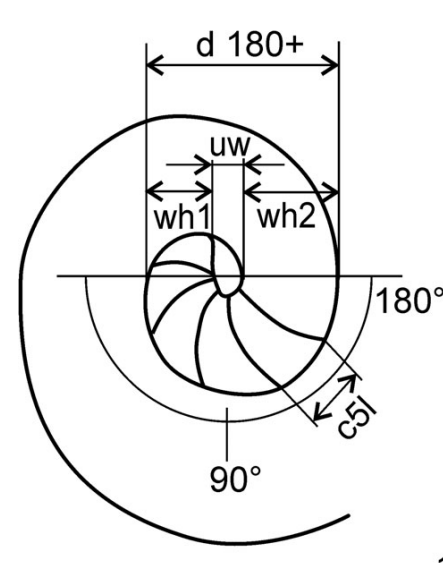

$1 / 4 \mathrm{~W}$

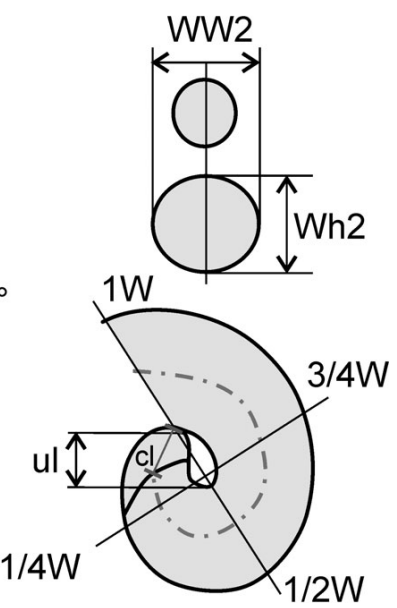

Figure 2. Schematic drawing of measured morphological features (Tables 1,2) in Ophioceras; $\mathrm{cl}=$ length of initial chamber measured along the axis as a distance between apex and first septum; $c 51=$ ventral length of $5^{\text {th }}$ phragmocone chamber, d $180+=$ conch diameter at $180^{\circ}$ (going by dorsal end of initial chamber and center of coiling), uw $=$ width of umbilical perforation, $\mathrm{ul}=$ length of umbilical perforation, $w \mathrm{wh} 1, \mathrm{wh} 2=$ whorl heights, ww $=$ whorl width; $1 / 4 \mathrm{w}-1 \mathrm{w}=$ one quarter to one whorl (i.e. complete turn of conch axis through 360 degrees).

from the adjacent part of the conch by the first septum. However, the term's meaning was discussed controversially among nautiloid researchers (e.g. Hyatt 1894, Balashov 1962, Teichert 1964, Bizikov 2008). The term seemed appropriate for cephalopods with an inflated bulbous apical part, separated superficially from the rest of the phragmocone by a distinct constriction (Balashov 1962, Flower 1964). However, the term "protoconch" was abandoned recently in ammonoids to avoid confusion (De Baets et al. 2015). In many cephalopods, especially Early Palaeozoic nautiloids including Ophioceras, a constriction between the first and the second chamber is missing. In addition, the course of growth lines and the orientation of the first septum are remarkably incongruent in the curved initial part of the conch. While almost transverse fine growth lines document the translocation of the aperture, the first suture forms a sharp angle with growth lines. This lack of congruency between the first growth line and the first suture indicates that the ventral and dorsal adapertural margins of such "protoconchs" were secreted at different times. Therefore, in accordance with the terminology used by Stenzel (1964) for Nautilus, we prefer the term "first" or "initial" chamber.

\section{Hatching indication in tarphycerids}

Tarphycerids (Early Ordovician-late Silurian) with tightly coiled conchs are the oldest cephalopods with a supposedly nektonic mode of life resembling extant Nautilus (Kröger 2005, Kröger \& Landing 2008). The time of hatching can be determined in fossil nautiloids by applying an actualistic approach using information from the early embryonic development of extant Nautilus (Stenzel 1964, Arnold et al. 1987, Mutvei et al. 1993, Mutvei \& Doguzhaeva 1997). It appears to work well for post-Palaeozoic nautilids, in which freshly hatched juveniles look like miniature adults. The most reliable indication for hatching in conch morphology is the nepionic constriction (Stenzel 1964, p. K82), which was hitherto documented only in representatives of the order Nautilida (Shimanski \& Zhuravleva 1961, Dzik 1984). Appearance of the hyponomic sinus on juvenile conchs of Nautilus as another useful feature for determination of the postembryonic stage (Stenzel 1964) has little value for the exact determination of the embryonic/postembryonic boundary due to its gradual development in $O p$ hioceras. However, its development is important for the reconstruction of swimming abilities of hatchlings. Changes in sculpture may represent an important clue since this might be linked with hatching, but frequently, the sculpture changes gradually during growth. Moreover, as demonstrated in extant Nautilus, a sudden change in sculpture occurs already in the egg capsule (Hyatt 1894, pl. 1). Therefore, changes in sculpture need to be considered carefully.

As data concerning the conch surface of tarphycerids is still scarce, changes in sculpture have not been used to determine the end of embryonic development. By contrast, the inner morphology of tarphycerid conchs has been much better documented. Therefore, the first septal approximation has been used to identify the point of hatching in tarphycerids. A decrease in length of the $8^{\text {th }}$ phragmocone chamber in recent Nautilus is supposed to be a reliable feature for the beginning of the post-embryonic stage. Closer spacing of the $7^{\text {th }}$ to the $8^{\text {th }}$ septum has been interpreted as retardation of growth, reflecting stress on the juvenile after hatching (Naef 1921-1923, Arnold et al. 1987, Chirat 2001). A similar case was documented in the Cretaceous nautilid Eutrephoceras dekayi (Morton, 1833) in which septa 4 and 5 are more closely spaced than preceding septa. The nepionic constriction lies about one third of a whorl ahead of the first approximated septum (Landman et al. 1983), thus corroborating the possible correlation of septal crowding with the end of the embryonic phase. With regards to the scarcity of observations concerning changes in sculpture, Schindewolf (1934), followed by Stumbur (1959) and Shimanski \& Zhuravleva (1961), supposed that a sudden decrease in length of phragmocone chambers indicates the beginning of the post-hatching phase in tarphycerids. However, a causal relation between septal spacing and hatching in Ordovician and Silurian tarphycerids is equivocal, because some results are contradictory.

According to Shimanski \& Zhuravleva (1961, p. 4), there were two pathways of early ontogenetic development in Tarphycerida: 1 - the conch in the egg capsule had one or two, or rarely three chambers plus the body chamber, 
and thus the hatchling differed substantially from an adult in having a curved conch; 2 - the embryonic conch consisted of five to eight chambers and the body chamber. As in Nautilus, the hatchling with coiled conch did not differ substantially from an adult. Stumbur (1962) held a similar view concerning tarphycerid early ontogeny.

However, the pattern of early ontogeny appears to be an evolutionarily rather conservative feature and it is difficult to accept such a variability in early ontogenetic development within an evolutionary lineage that otherwise archives such a conservative morphology through time. The basic question is: Is the first distinct septal approximation in tarphycerids really linked with hatching? Taking the two different ontogenetic strategies into account together with the fact that the septal crowding between the $7^{\text {th }}$ and $8^{\text {th }}$ septa is not always developed in Nautilus (Stenzel 1964, p. K86), the present concept of early tarphycerid ontogenetic development needs revision.

Independent evidence for the post-hatching phase is the appearance of such repaired sub-lethal damage, which was undoubtedly caused to juveniles after leaving the egg capsule (Stenzel 1964, Arnold et al. 1987, Chirat 2001). However, such injuries occurred throughout post-embryonic growth. Moreover, the apical part of the conch is only occasionally preserved. Therefore, we need to search for the ontogenetically earliest sublethal damage. Some growth anomalies could also have occurred still inside the egg capsule (Eichler \& Ristedt 1968, Arnold et al. 1987), e.g., in an egg attached to an uneven surface (Chirat 2001). Such rarely occurring anomalies need to be distinguished from healed post-embryonic damage caused by predators. It may help to analyze conchs by comparing anomalies of hatchling conchs against those of pre-mature conchs. This is the approach followed in this paper.

\section{Systematic position of Ophioceras}

The systematic position of Ophioceras Barrande, 1865 has long been a matter of discussion. Barrande (1855) originally assigned $O$. simplex to the genus Lituites Bertrand, 1763 and speculations about the relationships of those genera have persisted for a long time (Balashov 1962, Furnish \& Glenister 1964, Dzik 1984). Ophioceras has a conch shape, siphuncle position, and apertural modifications similar to Lituites (suborder Lituitina Dzik, 1984). By contrast, Ophioceras differs in having a thin walled siphuncle, which does not open into the camerae in adult stages, the conch lacks cameral deposits, and the retractor muscle scar is positioned ventrally (dorsal in Lituites), forming a single lobe (in Turek 1972: fig. 1; Fig. 1C-E) an unusual feature among nautiloids (Mutvei 1957, 2002). The similar shape of the constricted aperture in Ophioceras to that of some lituitids is likely a convergence. Similar apertural modifications appeared in several nautiloids like the oncocerid Hercoceras Barrande, 1865 (Turek 2007) or the ascocerid Glossoceras Barrande, 1865 (Miller 1932).

The phylogenetic derivation of Ophioceras from the poorly known Upper Ordovician Antiplectoceras Foerste \& Savage, 1927 (Dzik 1984) is poorly supported. Antiplectoceras has a more robust conch than Ophioceras with a wider umbilical perforation and prominent ribbing of the juvenile whorl starting near the apex. Internal structures in Antiplectoceras are unknown.

The subventral siphuncle in the embryonic conch of Ophioceras appears to be a plesiomorphic feature retained from its ancestors. Morphology of the embryonic conch in Ophioceras suggests a close affinity to the Trocholitidae Chapman, 1857, especially to Curtoceras Ulrich et al. 1942 (Ordovician) and Trocholites Conrad, 1838 (Ordovician and early Silurian, Holland 2010). Consequently, derivation of Ophioceras from the latter genus is assumed. In Curtoceras and Trocholites the caecum conjoins to the ventral side of the first chamber, but the siphuncle penetrates the septum subventrally. In the following chambers, the siphuncle moves more towards the center. In adult Ophioceras, the siphuncle position is slightly shifted ventrally from the center. Occasionally, it may be located between the center and the dorsum (Stridsberg \& Turek 1997). In Discoceras Barrande, 1867 (Discoceratidae Dzik, 1984); the caecum is in contact with the venter only in its proximal end, but the siphuncle penetrates the first septum more centrally, reaching a dorsal position in the $3^{\text {rd }}$ chamber.

Thin connecting rings of Ophioceras led Balashov (1962) to place the genus in the suborder Barrandeoceratina. Nevertheless, the thin connecting rings are a derived feature, and the decrease in thickness of connecting rings is documented in several lineages of cephalopods as a consequence of a long-term macroevolutionary trend in ectocochleate cephalopods (Kröger 2003). Thin connecting rings as well as the coarse sculpture associated with radial ribs are results of a convergence with the earliest nautilids (Lechritrochoceratidae). These evolutionary novelties might explain the survival of Ophioceras as the only tarphycerid throughout the late Silurian (about seven million years). Moreover, retractor muscle scars with single ventral lobes have been documented only for tarphycerids (Mutvei 1957, 2013) and not for the earliest nautilids (formerly assigned to barrandeocerids), where a pair of ventrolateral retractor muscles is characteristic (Turek 1975, 1976).

\section{Morphology of embryonic and early juvenile conch in Ophioceras}

The earliest growth stages of Ophioceras were discussed and illustrated by Barrande (1865, 1866, 1877a, b), Holm 
Table 1. Basic parameters measured on first whorl in Ophioceras simplex (in mm). Abbreviations: $\mathrm{d}$ max - maximum diameter of coiled part of conch; er - expansion rate $\left(=\right.$ wh2/wh1); ${ }^{*}$ - polished sections; other abbreviations dealing with measured parameters see Fig. 2 . N - number of specimens measured, MIN - minimum value, Q1 - first quartile, MED - median, Q2 - third quartile, Max - maximum value, SD - standard deviation.

\begin{tabular}{|c|c|c|c|c|c|c|c|c|c|c|c|c|c|c|c|}
\hline No. & d $180+$ & uw & wh1 & wh2 & er & $\mathrm{d} \max$ & $\mathrm{cl}$ & No. & d $180+$ & uw & wh1 & wh2 & er & $\mathrm{d} \max$ & $\mathrm{cl}$ \\
\hline NM-L 7840 holotyp & 5.0 & 0.9 & 1.6 & 2.5 & 1.6 & 22.0 & & NM-L 42295 & 5.2 & 0.5 & 1.8 & 2.9 & 1.6 & & 1.2 \\
\hline NM-L 28701 & 4.6 & 0.3 & 1.6 & 2.7 & 1.7 & & & NM-L 42297 & 4.8 & 0.3 & 1.8 & 2.7 & 1.5 & 22.0 & \\
\hline NM-L 28702 & 4.1 & 0.3 & 1.3 & 2.5 & 1.9 & 16.1 & 1.5 & NM-L 42298 & 5.2 & 0.4 & 1.7 & 3.1 & 1.8 & & 1.0 \\
\hline NM-L 28703 & 5.2 & 0.3 & 1.7 & 3.0 & 1.8 & 21.8 & & NM-L 42301 & 4.2 & 0.4 & 1.5 & 2.1 & 1.4 & 22.0 & 1.3 \\
\hline NM-L 28708 & 6.4 & 0.7 & 1.7 & 4.0 & 2.3 & & 1.7 & NM-L 42302 & 6.0 & 1.0 & 1.9 & 4.0 & 2.1 & 27.0 & \\
\hline NM-L 28709 & 4.5 & 0.3 & 1.5 & 2.7 & 1.8 & & & NM-L 42303 & 5.0 & 0.6 & 1.5 & 2.9 & 1.9 & & \\
\hline NM-L 28710 & 5.2 & 0.6 & 1.3 & 3.1 & 2.1 & 23.5 & & NM-L 42308 & 4.6 & 0.5 & 1.4 & 2.7 & 1.9 & 22.5 & 1.5 \\
\hline NM-L 29065 & 5.9 & 0.4 & 2.3 & 3.2 & 1.4 & & 1.5 & NM-L 42309 & 5.1 & 0.3 & 1.7 & 3.0 & 1.8 & & \\
\hline NM-L 28711 & 5.0 & 0.7 & 1.5 & 2.8 & 1.9 & 20.6 & 1.5 & NM-L 42310 & 5.9 & 0.5 & 2.0 & 3.4 & 1.7 & 22.0 & 1.4 \\
\hline NM-L 31845 & 5.1 & 0.6 & 1.7 & 2.8 & 1.6 & & & NM-L 42313 & 5.0 & 0.4 & 1.6 & 3.0 & 1.9 & & \\
\hline NM-L 31846 & 5.2 & 0.8 & 1.6 & 2.8 & 1.7 & & & NM-L 42316 & 5.0 & & & & & 26.0 & \\
\hline NM-L 31849 & 5.0 & 0.4 & 1.6 & 3.0 & 1.8 & & & NM-L 42317 & 5.5 & 0.8 & 1.5 & 3.2 & 2.1 & & \\
\hline NM-L 31857 & 5.5 & 0.5 & 2.0 & 3.0 & 1.5 & 25.0 & & NM-L 42318 & 5.1 & & 1.5 & & & 21.0 & \\
\hline NM-L 31858 & 4.6 & 0.3 & 1.5 & 2.8 & 1.9 & & & NM-L 42320 & 5.8 & 0.3 & 2.2 & 3.3 & 1.5 & & \\
\hline NM-L 31859 & 5.2 & 0.5 & 1.9 & 2.8 & 1.5 & & 1.8 & NM-L 42321 & 4.9 & 0.5 & 1.6 & 2.8 & 1.7 & & \\
\hline NM-L 31863 & 5.3 & 0.7 & 1.5 & 3.1 & 2.1 & 19.0 & 1.7 & NM-L 42322 & 5.0 & 0.7 & 1.3 & 3.0 & 2.3 & & \\
\hline NM-L 31869 & 4.8 & 0.5 & 1.5 & 2.8 & 1.9 & & 1.1 & NM-L 42323 & 4.8 & 0.3 & 1.5 & 3.0 & 2.0 & 19.0 & \\
\hline NM-L 31899 & 5.5 & 0.5 & 2.0 & 3.5 & 1.7 & & 1.8 & NM-L 42325 & 4.5 & 0.4 & 1.5 & 2.6 & 1.7 & 19.9 & \\
\hline NM-L 31897 & 4.7 & 0.5 & 1.5 & 2.5 & 1.7 & 18.8 & 1.5 & NM-L 42326 & 5.0 & 0.7 & 1.7 & 2.6 & 1.5 & 22.0 & \\
\hline NM-L 31900 & 5.0 & 0.5 & 1.7 & 2.8 & 1.6 & & & NM-L 42327 & 5.1 & 0.4 & 2.0 & 2.7 & 1.3 & 21.8 & \\
\hline NM-L 31908 & 5.2 & 0.4 & 1.8 & 3.0 & 1.7 & & & NM-L 42328 & 6.0 & 0.4 & 2.0 & 3.6 & 1.8 & & \\
\hline NM-L 31928 & 4.5 & 0.3 & 1.3 & 2.9 & 2.2 & 22.1 & & NM-L 42329 & 4.6 & 0.4 & 1.4 & 2.8 & 2.0 & & \\
\hline NM-L 43594 & 5.5 & 1.1 & 1.5 & 2.9 & 1.9 & 22.5 & & NM-L 42330 & 5.5 & 0.5 & 1.9 & 3.1 & 1.6 & & 2.0 \\
\hline NM-L 42246 & 5.2 & 0.8 & 1.6 & 2.8 & 1.8 & 23.0 & 1.5 & NM-L 42331 & 5.2 & 0.5 & 1.5 & 3.2 & 2.1 & & \\
\hline NM-L 42247 & 4.7 & 0.4 & 1.4 & 2.9 & 2.1 & & & NM-L 42333 & 5.0 & 0.3 & 1.5 & 3.2 & 2.1 & & \\
\hline NM-L 42248* & 5.1 & 0.8 & 1.7 & 2.6 & 1.5 & & & NM-L 42334 & 5.0 & 0.6 & 1.5 & 2.9 & 1.9 & & 1.2 \\
\hline NM-L 42250* & 5.3 & 0.5 & 1.9 & 2.9 & 1.5 & 22.1 & 1.2 & NM-L 42336 & 5.6 & 0.5 & 1.7 & 3.4 & 2.0 & 25.0 & \\
\hline NM-L 42251 & 5.6 & 0.4 & 2.0 & 3.2 & 1.6 & & 1.5 & NM-L 42337 & 4.8 & 0.4 & 1.6 & 2.8 & 1.7 & & \\
\hline NM-L 42261 & 5.3 & 0.5 & 1.7 & 3.1 & 1.8 & 24.3 & & NM-L 29063 & 5.2 & 0.7 & 1.7 & 2.8 & 1.6 & 21.0 & \\
\hline NM-L 42262 & 5.5 & 0.5 & 1.7 & 2.8 & 1.6 & & 1.5 & NM-L 42343 & 5.0 & 0.4 & 1.5 & 3.1 & 2.1 & & \\
\hline NM-L 42266 & 5.2 & 0.7 & 1.8 & 2.7 & 1.5 & 24.5 & 1.7 & NM-L 42344 & 5.1 & 0.4 & 1.7 & 2.9 & 1.8 & 22.4 & \\
\hline NM-L 42268 & 4.6 & 0.5 & 1.7 & 2.4 & 1.4 & & & NM-L 42345 & 5.0 & 0.5 & 1.5 & 3.0 & 2.0 & 20.2 & \\
\hline NM-L 42269 & 4.7 & 0.3 & 1.5 & 2.9 & 1.9 & 20.6 & & NM-L 42348* & 5.2 & 0.4 & 1.7 & 3.1 & 1.8 & & 1.2 \\
\hline NM-L 42270 & 4.6 & 0.6 & 1.4 & 2.6 & 1.9 & 18.1 & & NM-L 42349* & 4.6 & 0.5 & 1.6 & 2.5 & 1.6 & & \\
\hline NM-L 42272 & 5.0 & 0.4 & 1.7 & 2.9 & 1.7 & 26.0 & 1.3 & NM-L 42351 & 5.0 & 0.6 & 1.5 & 2.9 & 1.9 & 25.3 & 1.5 \\
\hline NM-L 42274 & 5.1 & 0.4 & 1.7 & 3.0 & 1.8 & 20.8 & 2.1 & NM-L 43157 & 5.7 & 0.3 & 1.7 & 3.7 & 2.2 & & \\
\hline NM-L 42277 & 5.3 & 0.7 & 1.8 & 2.9 & 1.6 & & & NM-L 43159 & 5.7 & 0.5 & 2.0 & 3.2 & 1.8 & 20.1 & \\
\hline NM-L 42275 & 5.1 & 0.6 & 1.8 & 2.7 & 1.5 & & 1.6 & NM-L 42352 & 5.0 & 0.4 & 1.5 & 3.1 & 2.1 & & 1.8 \\
\hline NM-L 42278 & 5.0 & 0.4 & 1.7 & 2.9 & 1.7 & & & NM-L 43160 & 6.0 & 0.8 & 1.9 & 3.3 & 1.7 & & \\
\hline NM-L 42280 & 5.2 & 0.6 & 1.7 & 2.9 & 1.7 & 21.0 & & NM-L 43166 & 5.5 & 0.5 & 1.8 & 3.2 & 1.8 & & 2.1 \\
\hline NM-L 42283 & 4.3 & 0.4 & 1.2 & 2.7 & 2.2 & 18.0 & & NM-L 46526 & 5.4 & 0.6 & 1.7 & 3.1 & 1.7 & 17.9 & \\
\hline NM-L 42284 & 5.1 & 0.5 & 1.5 & 3.1 & 2.1 & & & NM-L 43590 & 5.5 & 0.6 & 1.9 & 3.0 & 1.6 & 25.7 & \\
\hline NM-L 42285 & 5.3 & 0.5 & 1.7 & 3.1 & 1.8 & 26.0 & & NM-L 43592 & 5.0 & 0.7 & 1.5 & 2.8 & 1.9 & & \\
\hline NM-L 42286 & 4.9 & 0.6 & 1.5 & 2.8 & 1.9 & 21.6 & & NM-L 43591 & 7.0 & 1.0 & 2.6 & 3.4 & 1.3 & 34.0 & \\
\hline NM-L 42288 & 4.9 & 0.1 & 1.4 & 3.4 & 2.4 & 18.0 & & $\mathrm{~N}$ & 95 & 93 & 94 & 93 & 93 & 47 & 31 \\
\hline NM-L 42289 & 5.3 & 0.6 & 1.8 & 2.9 & 1.6 & & & MIN & 4.1 & 0.1 & 1.2 & 2.1 & 1.3 & 16.1 & 0.8 \\
\hline NM-L 42290 & 5.2 & 0.8 & 1.6 & 2.8 & 1.7 & 21.7 & 1.2 & Q1 & 4.95 & 0.4 & 1.5 & 2.8 & 1.6 & 20.6 & 1.25 \\
\hline NM-L 42291 & 4.5 & 0.4 & 1.5 & 2.6 & 1.7 & 23.0 & & MED & 5.1 & 0.5 & 1.6 & 2.9 & 1.8 & 22 & 1.5 \\
\hline NM-L 42292 & 5.0 & 0.5 & 1.6 & 2.9 & 1.8 & 21.1 & 1.4 & Q2 & 5.3 & 0.6 & 1.775 & 3.1 & 1.9 & 23.9 & 2.1 \\
\hline NM-L 42293 & 5.0 & 1.0 & 1.2 & 2.8 & 2.3 & 27.9 & & MAX & 7 & 1.1 & 2.6 & 4 & 2.4 & 34 & 2.1 \\
\hline NM-L 42294 & 5.2 & 0.5 & 1.5 & 3.2 & 2.1 & & 0.8 & $\underline{\mathrm{SD}}$ & 0.45 & 0.18 & 0.23 & 0.31 & 0.24 & 3.11 & 0.30 \\
\hline
\end{tabular}


(1885), Angelin \& Lindström (1880), Lindström (1890), Hyatt (1894), Shimanski \& Zhuravleva (1961), Dzik (1984), and Stridsberg \& Turek (1997). These authors gave only very short descriptions of these growth stages without interpretation of embryonic development or the point of hatching.

\section{The initial chamber}

The morphology of the first chamber is similar in both species of Ophioceras (O. simplex, O. rudens). The first chamber is curved and cup-shaped with a blunt apex (Figs 3A, D, 4, 5A, C, F, 7A, C, D, 9, 11A, F, 12A-C). Whorl height (whl, Fig. 2) in $O$. simplex varies between $1.2-2.6 \mathrm{~mm}(\mathrm{~N}=94)$. Length of the first chamber is $0.8-2.1 \mathrm{~mm}(\mathrm{~N}=31$; Table 1$)$, this first chamber is usually long, only exceptionally it may be very short (0.8 mm, specimen RM-Mo 59120, Fig. 12A). Whorl height (whl) in $O$. rudens varies between 1.6-2.6 mm (most common value and median is $1.8 \mathrm{~mm}$ ), length $0.8-1.6 \mathrm{~mm}$, but in order to assess variability correctly, the number of measurable specimens is too low $(\mathrm{N}=10, \sigma=0.31$; Table 2).

The apical end of the siphuncle (caecum) in both species is well calcified, tubular, and the distal end of the caecum may be slightly inflated (Figs 12B, 13A). Its length depends on the length of the $1^{\text {st }}$ phragmocone chamber. It reaches to about $1 / 3$ to $1 / 2$ of the length of the first chamber. The distal part of the caecum is ventrally in contact with the conch wall of the first chamber (Fig. 12B, C), or the whole caecum ventrally adjoins to the wall of the chamber (Figs 12A, 13A). The caecum measures $0.3 \mathrm{~mm}$ in diameter in $O$. simplex, $0.4 \mathrm{~mm}$ in $O$. rudens.

The apical part of the initial chamber exhibits a flattened area surrounded by a relatively large elliptical cicatrix (Fig. 4). This primordial conch or initial plate (Arnold et al. 1987, Mutvei et al. 1993) was flat and relatively large, surrounded by a very slight groove. The cicatrix was observed in one specimen only. In Ophioceras, it is commonly covered with a lamella of the dorsal conch wall of the second whorl and firmly attached to the apical portion of the initial chamber.

In median sections, the conch outline of the $1^{\text {st }}$ phragmocone chamber usually forms a curve in which the dorsum smoothly continues to the venter (Fig. 12). Exceptionally, the outline of the $1^{\text {st }}$ chamber in O. simplex is almost sub-angular (NM-L 42250, Fig. 13B).

The surface of the first chamber (except the most apical part) bears very fine, densely spaced growth lines (Figs 3C, $5 \mathrm{~A}, \mathrm{C}, 9 \mathrm{C}, \mathrm{F}$ ) or is almost smooth (Figs 3A, 5F, 7B, 8B, D). The latter case may be a result of preservation. In four specimens of $O$. simplex, a distinct transversal ridge or groove crossing the smooth apical part has been observed (Figs 7B, C, 8A).
Table 2. Basic parameters measured (in $\mathrm{mm}$ ) on first whorl in Ophioceras rudens. For abbreviations see Fig. 2.

\begin{tabular}{lccccccc}
\hline No. & d 180+ & uw & wh1 & wh2 & er & d max & cl \\
\hline NM-L 9097 & 4.8 & 0.4 & 1.8 & 2.6 & 1.4 & & 0.9 \\
NM-L 9102 & 5.2 & 0.5 & 1.8 & 2.9 & 1.6 & 36 & 1.2 \\
NM-L 28668 & 5.2 & 0.4 & 1.8 & 3.0 & 1.7 & & \\
NM-L 28670 & 5.0 & 0.4 & 1.6 & 3.0 & 1.6 & 32 & 1.6 \\
NM-L 28671 & 5.0 & 0.5 & 1.7 & 2.8 & 1.6 & & \\
NM-L 28696 & 6.0 & 0.4 & 2.6 & 3.0 & 1.2 & 33 & \\
NM-L 31891 & 5.1 & 0.6 & 1.8 & 2.7 & 1.5 & & \\
NM-L 42300 & 5.0 & 0.5 & 2.0 & 2.5 & 1.2 & 38 & 0.8 \\
NM-L 42311 & 5.0 & 0.4 & 1.8 & 2.8 & 1.5 & & \\
SM 15 & 5.2 & 0.8 & 1.8 & 2.5 & 1.4 & & \\
\hline N & 10 & 10 & 10 & 10 & 10 & 4 & 4 \\
MIN & 4.8 & 0.4 & 1.6 & 2.5 & 1.2 & 32 & 0.8 \\
MAX & 6 & 0.8 & 2.6 & 3 & 1.7 & 38 & 1.6 \\
\hline
\end{tabular}

\section{Embryonic and early juvenile conch shape}

Similar to extant Nautilus (see Arnold et al. 1987), embryonic and an adjacent part of juvenile conchs of Ophioceras are not perfectly spirally coiled. This part of the conch comprises the $1^{\text {st }}$ and the beginning of the $2^{\text {nd }}$ whorl. The first whorl diverged markedly from the ideal spiral in two different ways:

(i) In about $10 \%$ of all $O$. simplex specimens, the initial chamber partially stands in the way of further growth as the conch reaches one full whorl. The conch that grows around this initial chamber deviates from the "ideal" logarithmic spiral shape. Consequently, the juvenile conch acquired a "scaphitid" conch shape, i.e. the shape observed also in, e.g., the earliest growth stages of some Devonian goniatites (Erben 1962, De Baets et al. 2015) (e.g. Figs 5B, 6). Later in ontogeny, coiling of the conch more closely approximates a perfect logarithmic spiral. Such a conch form is seen in, e.g., specimen NM-L 42250 (Fig. 13A, a polished median section, conch with displaced $5^{\text {th }}-7^{\text {th }}$ septum resulting in false shortening of the $5^{\text {th }}$ to $7^{\text {th }}$ phragmocone chambers).

(ii) Less frequently, in about $5 \%$ specimens of $O$. simplex, the apical portion of the conch is only slightly curved, while the subsequent part of the whorl is tightly coiled (e.g. Fig. 3D). Exceptionally (NM-L 43157, Fig. 3D, RM-Mo 59120, Fig. 12A), the curvature of the earliest conch in $O$. simplex is weak, the dorsal side between the $1^{\text {st }}$ to $3^{\text {rd }}$ phragmocone chambers is almost flat and the ventral side is markedly curved. This results in the drop-shaped umbilical perforation being very narrow.

The different mode of coiling is coupled with variability in conch expansion. The expansion rate (er) of the early conch in $O$. simplex is highly variable (1.3 to 2.1 with a mean value of 1.8 , see Table 2 ). Some specimens display a very rapidly expanding first half of the first whorl (e.g. NM-L 42288, Fig 3B, NM-L 42285, Fig. 7A, NM-L 42286, Fig. 7B). However, in later growth stages, the 
conch expansion rate remains equal in all specimens. To calculate the conch expansion rates in Ophioceras, Stridsberg \& Turek (1997) used a revolving index (ri), i.e. the ratio of the whorl height to the whorl height of the previous whorl. The revolving index in later growth stages of O. simplex is 1.7 , with only a few exceptions (Stridsberg and Turek 1997). Although the er describes only half a whorl and only in a very early growth stage while the $r i$ includes one complete whorl, the comparison of these values reveals that the expansion rate in juvenile and later ontogenetic stages is markedly lower than in the earliest growth stage.

Generally, conch coiling in $O$. rudens more closely approaches the ideal logarithmic spiral (Fig. 9) than it does in $O$. simplex and the shape of the juvenile conch in $O$. rudens is rather uniform (Fig. 9) with er-values between 1.2-1.6 (Table 3). In later stages, the conch expansion rate of $O$. rudens expressed by means of the $r i$ is rather constant and low with values around 1.3 (Stridsberg \& Turek 1997).

The abrupt and most striking change in coiling of the conch axis in $O$. simplex often more or less coincides with the first prominent change in sculpture. It is located approximately at $1 / 4$ of the first whorl (e.g. Figs 3D, 8B, 16B), where occasionally a dorsolateral groove appears early in ontogeny.

\section{Sculpture of the first whorls}

The juvenile sculpture of Ophioceras consists of growth lines passing into more raised growth ridges, longitudinal (spiral) ridges and transverse ribs. Occasionally, smaller second order ribs are inserted between main ribs in the first whorl.

\section{Growth lines}

Growth lines appear (in the best preserved specimens) near the apex (e.g., NM-L 31921, Fig. 9C, NM-L 249, Fig. 9F) where they are very fine and difficult to discern. The most apical part of the conch is quite smooth. It may have occurred due to natural etching of the conch surface after the animal's death or due to diagenetic dissolution. Growth lines are densely spaced in the first quarter whorl, often transitioning abruptly into widely spaced growth lines (e.g., Figs 5C, F, 6B, 8C). During later growth, they become more pronounced and transform into more distinct ridges (lirae). One or two finer growth lines between two neighboring ridges are occasionally discernible. In the second half of the first whorl, these transverse markings are sub-parallel with ribs; they are oriented more obliquely to the conch axis during subsequent growth (e.g., NM-L 42289, Figs 5F, 8D). However, near the aperture of mature specimens, the course of ribs and transverse ridges is again sub-parallel.

\section{Spiral ridges}

A fine reticulate sculpture, i.e. a combination of transverse and spiral ridges, is common in Ophioceras. The distinctiveness of the spiral ridges is highly variable in early ontogeny. In O. simplex the appearance of fine spiral ridges at about $1 / 4$ of the first whorl at the change in growth line spacing is the most common (Figs 3B, 5C, D, 6B, 8D, 10D, 15F, 16B). Then spiral ridges are commonly suppressed in the course of the first whorl. In some specimens of $O$. simplex (e.g. Figs 3B, 5D), a distinct reticulate sculpture is present after its appearance on the conch during the entire ontogeny. In $O$. rudens, a fine sculpture is typically reticulate, and sometimes already apparent the initial chamber (Fig. 9A).

\section{Transverse ribs}

Ribs are the most prominent sculptural element in Ophioceras. The first indications of ribs appear occasionally after the first quarter whorl. More frequently, ribs start in the middle of the first whorl (Figs 5A, F, 8C, D). The first ribs are not equally developed, but their distance increases with conch growth. Fully developed and regularly arranged ribs are usually present close to the end of the first whorl. They are distinct laterally and dorsolaterally, running obliquely to the conch axis. At the beginning of the second whorl, a marked difference between the course of growth ridges and ribs appears (Figs 5A, F, 8D) and growth lines form a more acute angle with the axis of the conch than the ribs. A distinct unconformity in the course of growth lines and ribs is an unusual feature in nautiloids. In some specimens, several second-order ribs are inserted between the main ribs (Figs 5B, 8B). They are present only on the first and beginning of the second whorl. Through ontogeny, they gradually disappear. Morphology of ribs as well as their density in O. simplex is highly variable (Stridsberg \& Turek 1997).

\section{Bicarinate venter}

The bicarinate, slightly concave venter is a feature characteristic of premature and mature stages of Ophioceras (Fig. 1C, E). First, venter becomes flattened (Fig. 15B, C). Secondly, this morphologic change is followed by the formation of two carinae near the end of the first whorl (Fig. 10A, B). During further growth, the carinae became more prominent. The carinae and their development in Ophioceras ontogeny is thus similar to carinae e.g. in the Early Devonian goniatite Gyroceratites Meyer, 1831 (Walliser 1962, Chlupáč \& Turek 1983). The whorl section near the aperture of embryonic conchs and in the first whorl is very slightly depressed in both Ophioceras species (Table 3), changing to slightly or moderately compressed during growth. Similarly, a great variation in cross section has also been found in adult specimens (Stridsberg \& Turek 1997). 

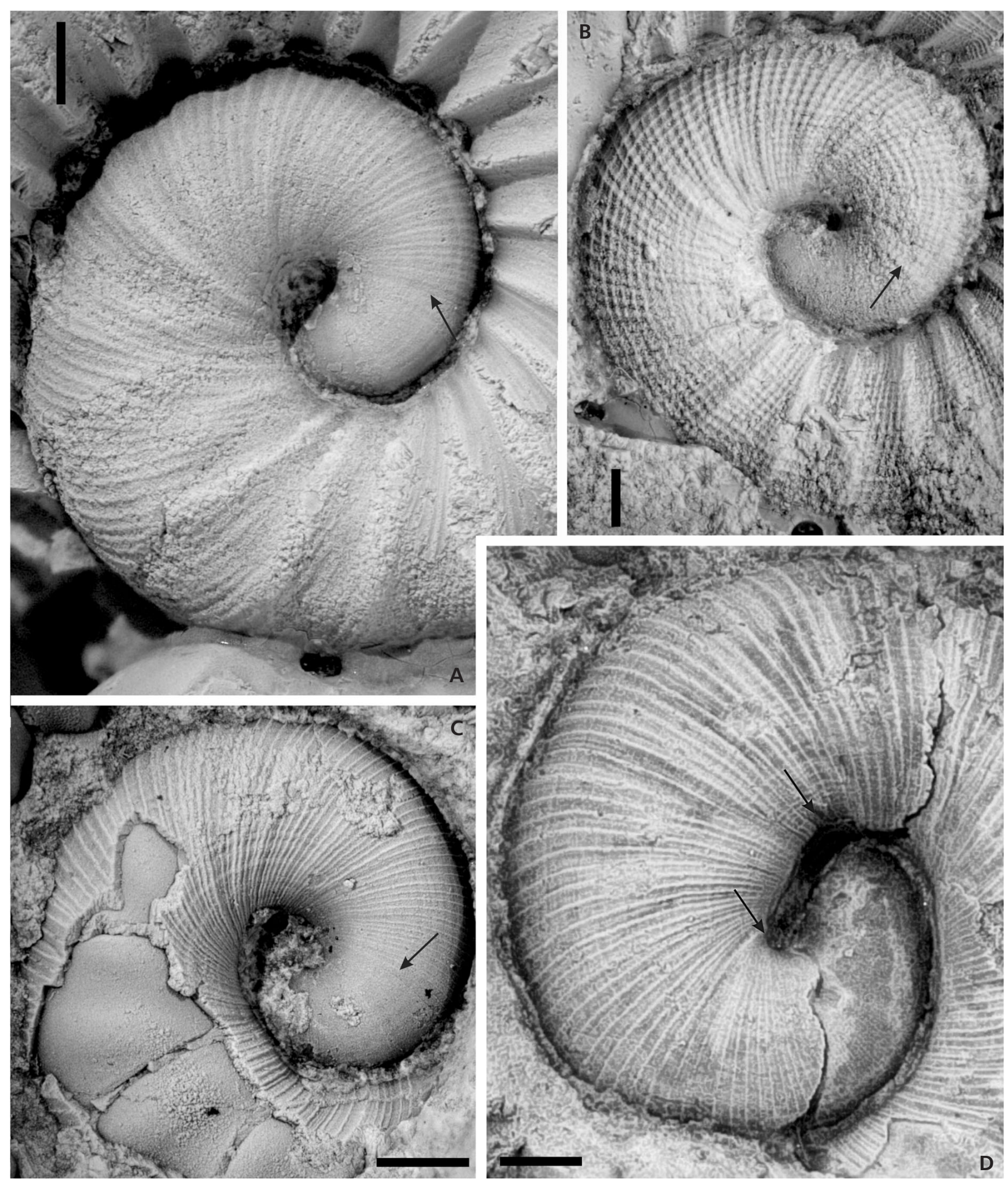

Figure 3. Early growth stages of Ophioceras simplex (Barrande, 1855) from Bohemia; lateral views. • A - NM-L 42292; Ludlow, Ludfordian, $P$. fragmentalis Zone (P. archiaci-A. modesta Community); Beroun, Kosov Quarry; note sharp boundary between almost smooth apical part and adjacent transversally sculptured part of the conch (arrow); spiral ridges quite suppressed. • B - NM-L 42288; Ludlow, Ludfordian; Praha-Velká Chuchle; rapidly expanding conch with small first chamber; note also sudden change of finely striated conch into coarsely cancelate (arrow). • C - NM-L 42334; late Ludlow or earlier Př́ídolí; Praha-Lochkov or Kosoř; juvenile conch with well-preserved sculpture; hatching manifested by appearance of more widely spaced growth lines indicated by arrow. • D - NM-L 43157; late Ludlow or earlier Př́ídolí; Praha-Lochkov or Kosoř; specimen showing rapid expansion of imperfectly coiled first whorl; arrows indicate sudden change in coiling and straight part of dorsal side. Scale bars equal $1 \mathrm{~mm}$. 
Table 3. Basic parameters in cross-section measured on first whorl (in $\mathrm{mm}) ; \mathrm{ad}-$ angle distance $\left(0^{\circ}=\right.$ dorsal position of first septum $)$, wh - whorl height, ww - whorl width; see Fig. 2.

\begin{tabular}{|c|c|c|c|c|c|}
\hline No. & & $\operatorname{ad}\left[{ }^{\circ}\right]$ & wh & ww & wh/ww \\
\hline NM-L 28708 & & 225 & 4.0 & 4.0 & 1.0 \\
\hline NM-L 28709 & & 180 & 2.6 & 3.0 & 0.9 \\
\hline NM-L 31908 & & 360 & 3.8 & 4.0 & 1.0 \\
\hline NM-L 43590 & & 360 & 3.0 & 3.2 & 0.9 \\
\hline NM-L 42254 & & 180 & 2.5 & 2.4 & 1.0 \\
\hline NM-L 42295 & & 360 & 3.4 & 3.2 & 1.1 \\
\hline NM-L 42298 & & 180 & 2.6 & 3.0 & 0.9 \\
\hline NM-L 42299 & O. simplex & 180 & 2.8 & 3.0 & 0.9 \\
\hline NM-L 42305 & & 260 & 3.5 & 4.0 & 0.9 \\
\hline NM-L 42320 & & 270 & 3.6 & 3.9 & 0.9 \\
\hline NM-L 42331 & & 270 & 3.0 & 3.4 & 0.9 \\
\hline NM-L 42333 & & 180 & 3.2 & 3.2 & 1.0 \\
\hline NM-L 42337 & & 180 & 3.0 & 3.4 & 0.9 \\
\hline NM-L 43166 & & 270 & 3.4 & 3.4 & 1.0 \\
\hline NM-L 42286 & & 360 & 3.2 & 2.9 & 1.1 \\
\hline NM-L 42311 & & 270 & 3.2 & 4.5 & 0.7 \\
\hline NM-L 9098 & O. rudens & 180 & 2.0 & 3.9 & 0.5 \\
\hline SM 15 & & 180 & 2.5 & 4.0 & 0.6 \\
\hline
\end{tabular}

\section{Dorsolateral grove in early conch - analogy of nepionic constriction}

A groove, found in four specimens of Ophioceras, extends from the umbilical shoulder radially, and disappears just before the lateral center of the flanks. It is situated approximately at $1 / 5^{-1} / 4$ of the whorl from the apex. Its course is parallel with growth lines and its position is associated with the change of conch sculpture and conch coiling (Figs 8B, 9B, 10D).

The nepionic constriction, commonly accentuated by a post-embryonic expansion of the whorl, is usually represented by a narrow groove displayed dorsolaterally in extant Nautilus. Frequently, instead of the constriction, a break in the conch is present, resulting in an unconformable course of growth lines (Arnold et al. 1987).

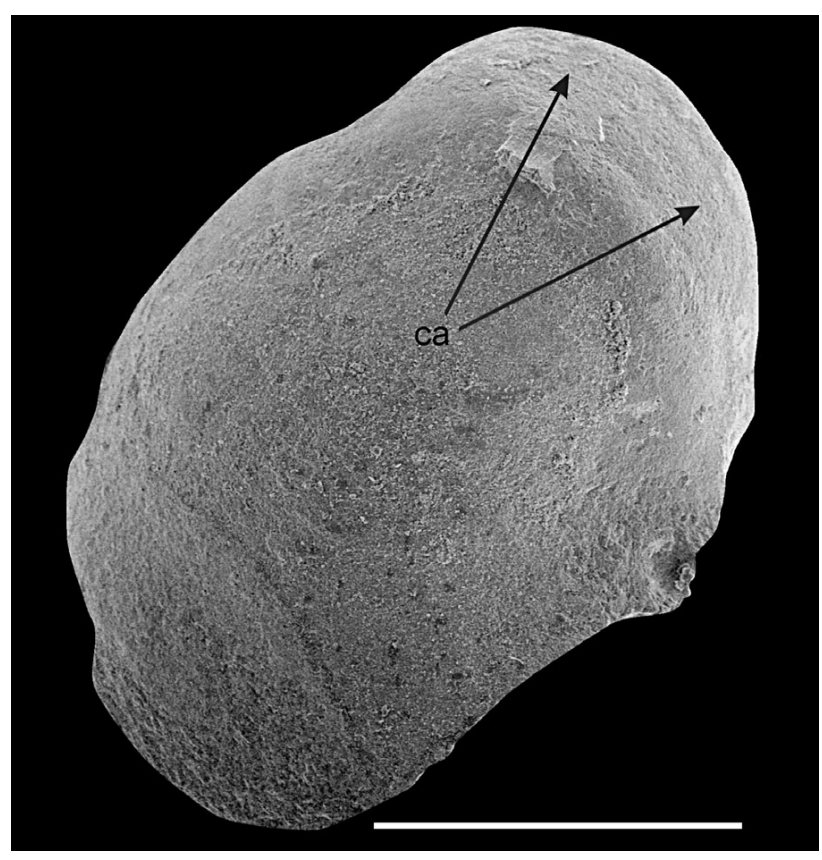

Figure 4. Apical part of Ophioceras simplex (Barrande, 1855) showing cicatrix (ca); SEM; dorsolateral view; NM-L43600, late Ludlow or earlier Př́ídolí; Praha-Lochkov. Scale bars equal $1 \mathrm{~mm}$.

\section{Hyponomic sinus}

The hyponomic sinus evolved gradually as a shallow lobe. It is well manifested by $1 / 2$ of the first whorl in both species of Ophioceras, and fully developed before the end of the $1^{\text {st }}$ whorl (Figs 9D, 10A, B).

\section{Internal structure of juvenile conch}

\section{Siphuncle development}

A cylindrical caecum adjoined to the ventral side of the first phragmocone chamber is developed in Ophioceras. Its shape can be explained by the contact of the distal part of the

Figure 5. Early growth stages of Ophioceras simplex (Barrande, 1855) from Bohemia, lateral views. • A - NM-L 42303; late Ludlow or earlier Přídolí; Praha-Lochkov or Kosoř; excellently preserved conch; slightly indicated ribs appear at midpoint of $1^{\text {st }}$ whorl, they are fully developed before end of $1^{\text {st }}$ whorl; arrow indicates sudden change of fine densely spaced growth lines into widely spaced growth lines. • B - NM-L 42318; late Ludlow or earlier Př́dolí; Praha-Lochkov or Praha-Kosoř; notice "scaphitid" shape of $1^{\text {st }}$ whorl (the most apical part damaged) and distinct transversal sculpture; spiral ridges completely suppressed. • C - NM-L 42284; late Ludlow or earlier Př́ídolí; Praha-Lochkov or Kosoř; first $1 / 4$ of whorl bears very fine growth lines, suddenly passing to more distinct growth lines (arrow 1), appearance of spiral ridges coincides with appearance of widely spaced growth lines; both indicate hatching phase; dorsolaterally in $1 \frac{1}{4}$ whorl conspicuous healed damage (hi). • D - NM-L 42291; Ludlow, Ludfordian, S. linearis Zone; Beroun-Dlouhá hora; distinct cancelate sculpture starting with beginning of the post-embryonic phase of growth (arrow); repairs of the conch in $1 \frac{1}{4}$ and $1 \frac{1}{2}$ whorls (sr). • E - NM-L 42331; late Ludlow or earlier Př́ídolí; Praha-Lochkov or Kosoř; sharp boundary between embryonic/juvenile stages manifested by change in sculpture (indicated by arrow), spiral ridges not visible; note also marked shortening of phragmocone chambers at $1 / 4$ of $2^{\text {nd }}$ whorl (sc). • F - NM-L 42289; late Ludlow or earlier Př́ídolí; Praha-Lochkov or Kosoř; appearance of spiral lirae and sharp boundary between densely and widely spaced growth lines indicating hatching stage (arrow); notice also the course of growth lines in relation to the course of ribs; the course of growth lines is parallel with ribs on $1^{\text {st }}$ whorl, distinct unconformity appears in their course on $2^{\text {nd }}$ whorl; healed breakage dorsolaterally on $2^{\text {nd }}$ whorl (hi). Scale bars equal $1 \mathrm{~mm}$ 
Vojtěch Turek \& Štěpán Manda • Early ontogeny, anomalous growth, and healed injuries in the Silurian nautiloid Ophioceras
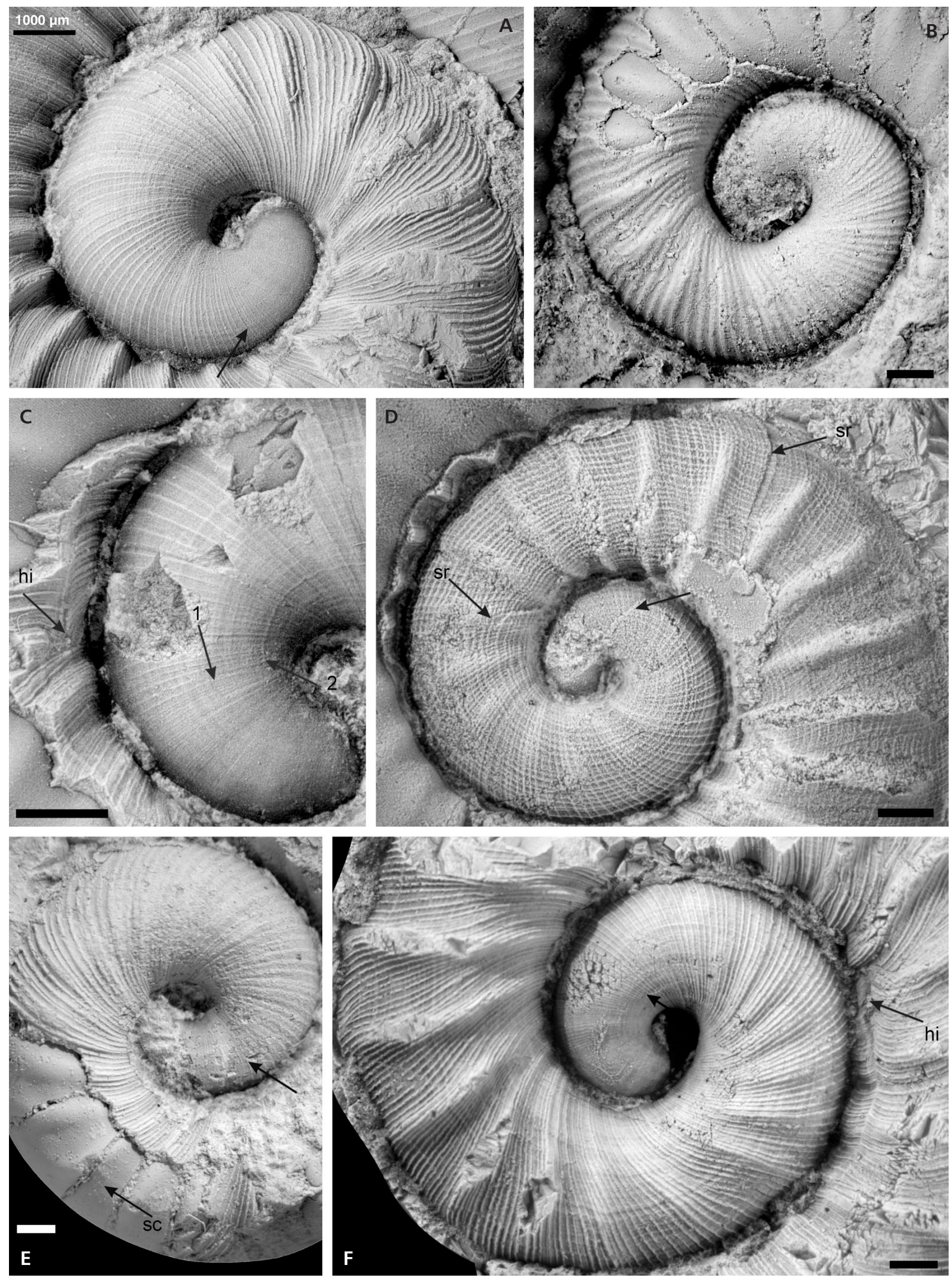

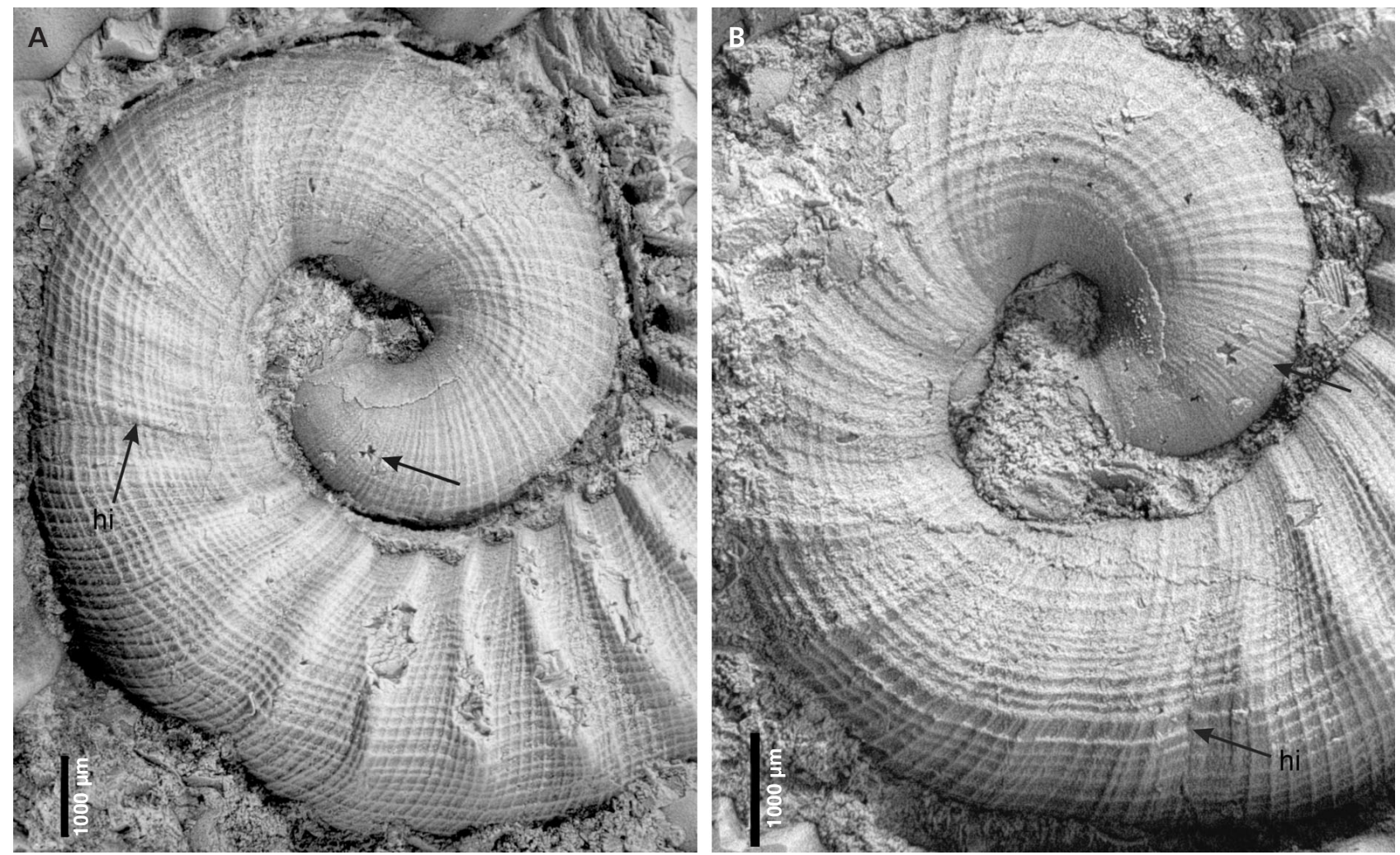

Figure 6. "Scaphitid" form of early juvenile conchs of Ophioceras simplex (Barrande, 1855) from Bohemia; initial chambers damaged; lateral views. - A - NM-L 42322; late Ludlow; vicinity of Prague; latex cast made from counterpart; notice changes in sculpture at $1 / 4$ whorl (arrow) and minor growth anomalies in second whorl (hi). • B - NM-L 42290; late Ludlow or earlier Př́dolí; vicinity of Prague; marked change in sculpture at $1 / 4$ of $1^{\text {st }}$ whorl (arrow) and abnormalities in sculpture at $1 \frac{1}{4}$ whorl (hi). Scale bars equal $1 \mathrm{~mm}$.

septal neck with the venter. The septal perforation in the first septum is located close to the venter, or at about $1 / 4$ of the whorl height. In the second septum, the septal perforation is slightly shifted dorsally; the siphuncle has reached its final position and does not change substantially during further growth (Figs 12,13). Exceptionally, in later whorls of $O$. rudens, the siphuncle is slightly shifted from the center dorsally (Stridsberg \& Turek 1997). There are no substantial differences in siphuncle diameter $(d s)$ dorsoventral shell diameter $(d v)$ ratio in different growth stages of $O$. simplex, where it is about $1 / 8$. The $d s / d v$ ratio in the second chamber of O. rudens (NM-L 28696, Fig. 12C) is $1 / 10$, and during subsequent growth, the ratio markedly increases to reach $1 / 5$.

\section{Septal spacing}

Septal spacing was examined in 37 specimens (Table 4, Figs 11-14). The first six phragmocone chambers in Ophioceras are generally long, with more regular spacing; variability in chamber length is much lower than in subsequent chambers. Marked shortening of chamber length usually occurs in the phragmocone chambers 7 to 9 , most commonly in the $8^{\text {th }}$ chamber, occasionally as early as the $5^{\text {th }}$ chamber. The change in septal spacing is located mostly near the end of the first whorl. Maximum chamber length varies only slightly in the first 11 chambers, but minimum chamber length suddenly increases in the $7^{\text {th }}$ chamber; the first quartile suddenly decreases in the $7^{\text {th }}$ chamber, but median phragmocone chamber length decrease in $8^{\text {th }}$ chamber (Fig. 14).

The change in septal spacing in Ophioceras is analogous to septal spacing in extant Nautilus, in which the $8^{\text {th }}$ chamber is usually shorter than the preceding chamber. Starting from the second whorl, there is a similar arrangement of septa in Ophioceras to that in Nautilus, in which septa are usually secreted at equal angular intervals, and the ratio of chamber volumes between adjacent chambers is rather constant (Fig. 11); only the last two or three septa are usually more closely spaced (Landman \& Cochran 1987). In Ophioceras usually the last chamber (Fig. 13A, B), occasionally two or three last chambers are shortened.

The total number of chambers in Ophioceras differs substantially, not only between both recognized species, but also varies within the species (Stridsberg \& Turek 1997). There is a relation between phragmocone chambers and arrangement of ribs on the conch. Usually, each chamber bears one rib, but there is a difference between the course of septa and ribs. While septa, with exception of the $1^{\text {st }}$ and $2^{\text {nd }}$ one, run almost transversally, ribs form larger 
Table 4. Changes in septal spacing in early ontogeny of Ophioceras simplex; phragmocone chamber length (chambers $2^{\text {nd }}-11^{\text {th }}$ ) measured as shortest distance between two neighbouring sutures on ventral (external) side of whorl (in $\mathrm{mm}$ ); see Fig. 2.

\begin{tabular}{|c|c|c|c|c|c|c|c|c|c|c|}
\hline Ph. chamber No. & 2 & 3 & 4 & 5 & 6 & 7 & 8 & 9 & 10 & 11 \\
\hline NM-L 43595 & & 2.0 & 2.0 & 1.9 & 1.7 & 1.3 & 1.2 & & & \\
\hline NM-L 43597 & & 2.0 & 2.0 & 2.0 & 2.1 & 1.9 & 1.2 & 1.3 & 1.8 & \\
\hline NM-L 43554 & 1.5 & 2.2 & 2.2 & 2.2 & 2.1 & 1.7 & 1.2 & 1.2 & 1.5 & \\
\hline NM-L 43596 & 1.7 & 1.8 & 2.2 & 2.2 & 2.2 & 2.2 & 2.0 & & & \\
\hline NM-L 23708 & 2.0 & 2.1 & 1.9 & 1.9 & 1.7 & 1.5 & & & & \\
\hline NM-L 28694 & 2.0 & 2.2 & 2.1 & 2.3 & 2.5 & 2.3 & 2.3 & 1.6 & 2.1 & \\
\hline NM-L 28709 & 2.1 & 2.0 & 2.1 & 2.0 & 1.7 & 1.4 & 1.4 & 1.4 & 1.2 & \\
\hline NM-L 28710 & & & 2.0 & 2.0 & 2.1 & 0.9 & 1.1 & 1.6 & 1.6 & 1.9 \\
\hline NM-L 31897 & 1.6 & 1.7 & 1.8 & 1.6 & 1.5 & 1.5 & 1.2 & 0.7 & 1.0 & 1.0 \\
\hline NM-L 46525 & & & 2.1 & 2.3 & 2.3 & 2.3 & 2.2 & 2.4 & & \\
\hline NM-L 42244 & & 1.8 & 2.1 & 2.2 & 2.3 & 2.1 & 2.0 & 1.5 & 1.3 & 1.2 \\
\hline NM-L 42246 & 2.0 & 2.1 & 2.2 & 2.0 & 2.0 & 1.9 & 2.0 & 1.7 & & \\
\hline NM-L 42247 & 1.6 & 1.8 & 1.8 & 1.9 & 1.8 & 1.5 & 1.3 & 1.1 & 1.2 & \\
\hline NM-L 42248 & 2.3 & 2.3 & 2.4 & 2.1 & 2.3 & 2.1 & 1.6 & 1.5 & & \\
\hline NM-L 42250 & 2.0 & 2.1 & 2.2 & 1.9 & 2.0 & 1.4 & 1.3 & 1.4 & 1.3 & 1.6 \\
\hline NM-L 42251 & 2.1 & 1.4 & 2.0 & 2.0 & 2.0 & 1.6 & 1.5 & 1.2 & & \\
\hline NM-L 42253 & 2.0 & 1.7 & 2.4 & 2.1 & 2.2 & 2.1 & 2.0 & 1.9 & 1.6 & 1.6 \\
\hline NM-L 42254 & 1.9 & 2.2 & 2.4 & 2.0 & 2.0 & 1.9 & 1.4 & 1.3 & & \\
\hline NM-L 42257 & $1.8^{*}$ & $1.8^{*}$ & 1.6 & 1.7 & 1.8 & 1.4 & 1.3 & 1.3 & & \\
\hline NM-L 42260 & 1.8 & 2.1 & 2.0 & 1.7 & & & & & & \\
\hline NM-L 42261 & & 1.8 & 2.4 & 2.3 & 2.0 & 2.1 & 2.0 & 1.5 & 1.3 & \\
\hline NM-L 42263 & 2.0 & 2.0 & 2.0 & 2.1 & 2.0 & 1.6 & 1.6 & 1.5 & 1.5 & \\
\hline NM-L 42264 & 2.2 & 2.2 & 2.1 & 2.1 & 2.0 & 1.8 & 1.4 & 1.4 & 1.3 & \\
\hline NM-L 42266 & 1.6 & 1.8 & 1.6 & 1.6 & 1.7 & 1.6 & 1.6 & 1.2 & 1.3 & \\
\hline NM-L 42284 & 2.0 & 2.0 & 2.3 & 2.2 & 2.1 & 2.4 & 2.2 & 2.1 & 2.0 & 2.0 \\
\hline NM-L 42292 & 2.2 & 2.0 & 2.1 & 2.3 & 2.3 & 2.2 & 2.0 & 1.9 & 2.0 & 1.7 \\
\hline NM-L 42299 & 1.6 & 1.7 & 1.9 & 1.8 & 2.0 & 2.0 & 2.0 & 1.8 & 1.4 & \\
\hline NM-L 42301 & 2.0 & 2.0 & 1.8 & 1.8 & 2.0 & 1.3 & 1.3 & 1.6 & 1.2 & \\
\hline NM-L 42302 & 1.9 & 2.2 & 2.1 & 2.2 & 2.1 & 2.1 & 1.6 & 1.8 & 2.0 & \\
\hline NM-L 42308 & 1.9 & 1.6 & 1.9 & 1.9 & 2.0 & 1.8 & 1.5 & 1.4 & 1.4 & \\
\hline NM-L 42316 & 1.7 & 2.0 & 2.2 & 2.2 & 2.4 & 2.0 & 1.9 & 1.7 & 1.6 & \\
\hline NM-L 42317 & & 1.5 & 1.7 & 1.9 & 2.1 & 2.0 & 1.9 & 1.5 & 1.6 & 1.5 \\
\hline NM-L 42345 & 1.8 & 1.8 & 2.0 & 1.7 & 1.8 & 1.6 & 1.1 & & & \\
\hline NM-L 42348 & 2.2 & 2.3 & 2.2 & 2.1 & 2.1 & 2.1 & 2.0 & 1.5 & 1.6 & \\
\hline NM-L 42349 & 2.0 & 2.0 & 2.1 & 1.7 & 1.7 & 1.5 & 1.4 & 1.5 & 1.7 & \\
\hline NM-L 43334 & 1.7 & 1.9 & 2.3 & 2.2 & 1.9 & 2.2 & 2.1 & 1.5 & 1.5 & \\
\hline NM-L 7840 - holotype & & & & 2 & 2 & 1.8 & 1.5 & & & \\
\hline $\mathrm{N}$ & 29 & 34 & 36 & 37 & 36 & 36 & 35 & 31 & 25 & 8 \\
\hline MIN & 1.5 & 1.4 & 1.6 & 1.6 & 1.5 & 0.9 & 1.1 & 0.7 & 1 & 1 \\
\hline Q1 & 1.7 & 1.8 & 1.975 & 1.9 & 1.875 & 1.5 & 1.3 & 1.35 & 1.3 & 1.425 \\
\hline MED & 2 & 2 & 2.1 & 2 & 2 & 1.85 & 1.6 & 1.5 & 1.5 & 1.6 \\
\hline Q2 & 2 & 2.1 & 2.2 & 2.2 & 2.1 & 2.1 & 2 & 1.65 & 1.6 & 1.75 \\
\hline MAX & 2.3 & 2.3 & 2.4 & 2.3 & 2.5 & 2.4 & 2.3 & 2.4 & 2.1 & 2 \\
\hline SD & 0.21 & 0.22 & 0.21 & 0.20 & 0.22 & 0.35 & 0.36 & 0.31 & 0.28 & 0.31 \\
\hline
\end{tabular}

angles with a radius. Similarly to fine sculptural elements, such an arrangement could improve strength of the conch. Ribs are not equally developed on the second half of the $1^{\text {st }}$ whorl, and there are some irregularities in their arrangement. Therefore, the relation between the position of ribs and septa is not obvious here.

\section{Hatching identification based on anomalous growth and conch repairs}

The changes in early conch morphology itself are not sufficient for the unequivocal determination of the point of hatching in tarphycerids. Other independent evidence for 

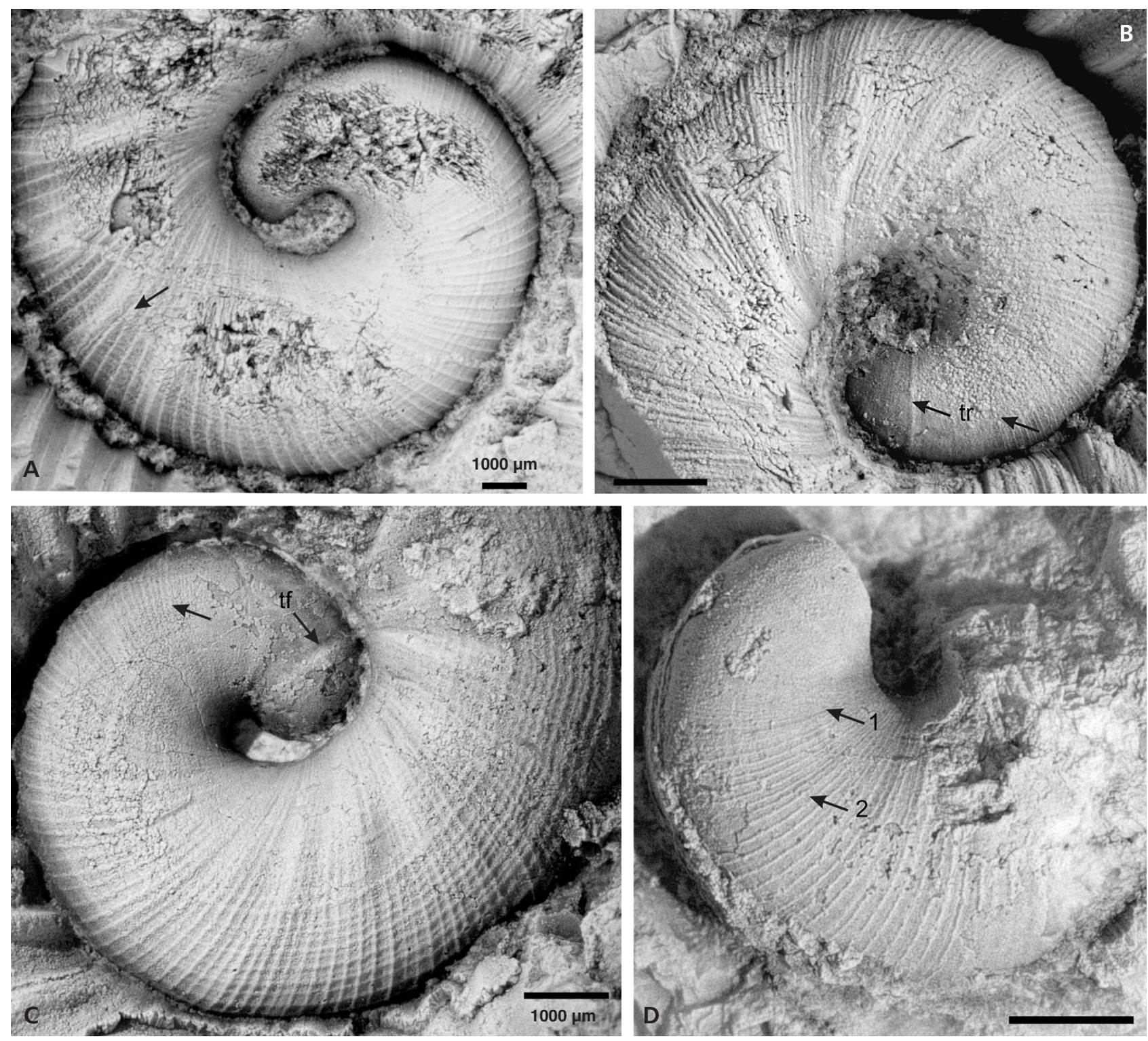

Figure 7. Early conchs of Ophioceras simplex (Barrande, 1855) from Bohemia, all lateral views. • A - NM-L 42285; late Ludlow; Praha-Lochkov; rapidly expanding conch; bifurcate transversal ridges near end of $1^{\text {st }}$ whorl (arrow). $\bullet$ B - NM-L 42286; late Ludlow or earlier Přídolí; Praha-Lochkov or Kosoř; distinct transversal ridge (tr) on $1^{\text {st }}$ chamber and changes in fine sculpture on early juvenile conch (arrow). $\bullet$ C - NM-L 42320; late Ludlow, vicinity of Prague; distinct transversal furrow (tf) on smooth apical part; second arrow indicates marked change in sculpture on border between embryonic/postembryonic stages. • D - NM-L 42268; late Ludlow, vicinity of Prague; sudden increase in spacing between growth lines (arrow 1) appears very early; additional increase in spacing between growth lines appears again (arrow 2); note also flattened apex of the conch. Scale bars equal 1 mm.

hatching is thus needed. Abnormalities in conch growth documented from some post-Palaeozoic nautilids may offer such evidence (Chirat 2001). The embryonic conch surface in Nautilus rarely displays repaired fractures, because embryonic development takes place largely covered by the egg capsule (Arnold et al. 1987). A similar condition is assumed for fossil nautiloids. First appearance of healed damage caused after hatching of the animal appears to be key to detect hatching in conchs of Ophioceras. However, it is essential to find a growth anomaly that unequivocally originated after hatching, i.e. healed bites and subsequent distinct growth anomalies.
We distinguish three types of healed injuries in the early juvenile growth stage of Ophioceras: a) shallow and wide dorsoventrally elongated depression; b) narrow and deep depression, V-shaped in cross section, gradually shallowing and afterwards disappearing during subsequent conch growth; such depressions are located laterally on the former apertural margin; c) anomalous growth of the whole conch. Similar growth anomalies occur in adults (see below). The sudden appearance of healed injuries, morphology of these injuries, coincidence of their location with changes in ornament and coiling all indicate that they are post-embryonic. 

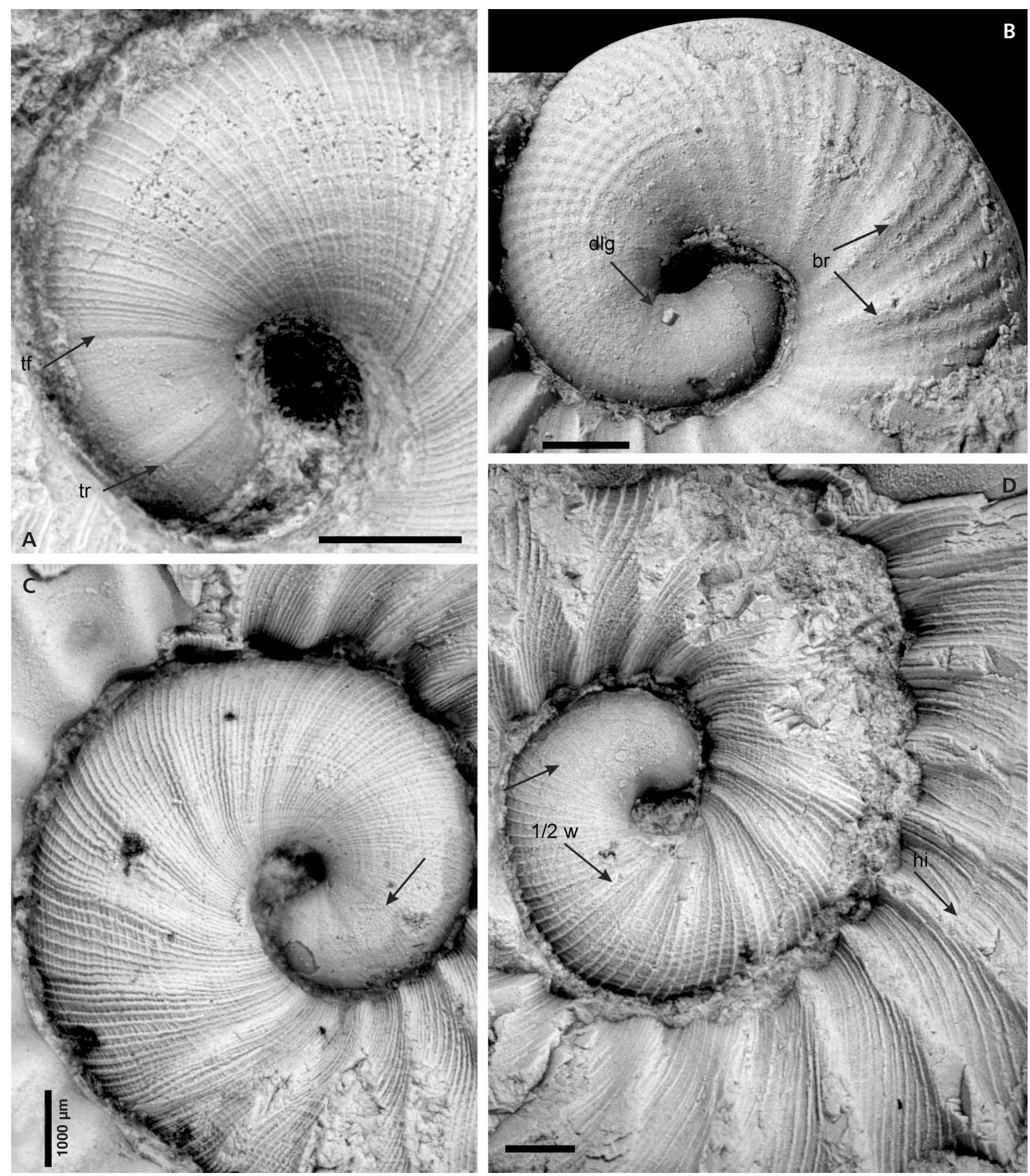

Figure 8. Early juvenile conchs of Ophioceras simplex (Barrande, 1855) from Bohemia, lateral views. • A - NM-L 42304; late Ludlow or earlier Př́́dolí; Praha-Lochkov or Praha-Kosoř; sharply demarcated boundary between smooth embryonic and distinctly transversally striated post-embryonic stages (narrow transversal furrow - tf), distinct transversal ridge adapically (tr) (apex covered by rock). B - NM-L 28708; late Ludlow, Praha-Velká Chuchle; marked change in coiling emphasized by short dorsolateral groove (dlg) indicating hatching; notice also unusually coarse conch sculpture, bifurcating ribs (br) with $2^{\text {nd }}$ order ribs between them. $\bullet$ C - NM-L 43160; early Ludfordian, Ludlow, S. linearis Zone; Zadní Kopanina or Beroun-Dlouhá hora; fine growth lines on adapertural part of embryonic conch; boundary between embryonic and postembryonic growth stages coincide with appearance of spiral ridges and widely spaced growth lines. • D - NM-L 42329; late Ludlow or earlier Př́dolí; Praha-Lochkov or Kosoř; spiral ridges appeared simultaneously with widely spaced growth lines (arrow); well developed ribs in half of $1^{\text {st }}$ whorl $(1 / 2 \mathrm{w})$; marked unconformity in course of growth lines and ribs starting at the end of $1^{\text {st }}$ whorl. Healed dorsolateral damage at $1^{3} / 4$ whorl (hi). Scale bars equal $1 \mathrm{~mm}$. 
Type a: A wide and shallow depression with anomalous development of growth lines is visible in specimen NM-L 42298 of O. simplex (Fig. 15A, C, F). At the end of the first quarter whorl (measured from the center of the umbilical perforation), a narrow transversal elevation resembling a rib is preserved. Just behind this elevation in adapertural direction, a shallow depression is situated dorsolaterally above the third septum (the septum can be seen in wet specimens). The depression is bordered both adapically and adaperturally by continuous grow lines. Transversal growth ridges, already very distinct ventrally and ventrolaterally, disappear in the depression. Six growth lines fade out approximately near the center of the flanks, and so this part of the depression is almost smooth. The next three growth lines gradually prolong dorsolaterally. The course of subsequent growth lines is continuous. The cause of the growth anomaly is unclear. It could be the result of pressure from a predator's jaws that lost their grip, and the organism escaped without causing further damage. The opposite side of the conch is not exposed and thus, we cannot further test this hypothesis. Also, the possibility that this conch deformation was caused in the egg capsule cannot be ruled out. However, the location of the growth anomaly on the conch, compared with the cases described below suggests a postembryonic origin. A similar growth anomaly, located ventrolaterally at $3 / 8$ of the first whorl, is preserved in specimen NM-L 46510 (Fig. 15D). The deep depression is elongated transversally; the course of growth lines was not affected by this deformation.

Type b: A deep and narrow depression was found in specimen NM-L 42310 of $O$. simplex (Fig. 16A, D). The apical part of the first chamber is smooth. Almost at the same position as in the previous specimen, a deep grove is present. It is situated laterally, at the beginning of the second quarter of the first whorl. It is a V-shaped depression (in transversal view), gradually shallowing and disappearing before the midpoint of the $1^{\text {st }}$ whorl. Faintly developed longitudinal (spiral) ridges appear laterally on the conch surface at the beginning of the second quarter of the first whorl. Well-developed ribs appear laterally on the first half whorl. A similar but less striking damage in an almost identical position has been found in specimen NM-L 42333 (Fig. 15E). This consists of laterally situated shallow depressions prolonged in the direction of growth, which diminish at about $1 / 4$ of the first whorl. Growth lines disap- pear inside the depression. Another marked growth anomaly presented in the same specimen is placed laterally near the end of the first whorl. It is expressed by the atypical morphology of the ribs.

Type c: Anomalous growth is displayed by specimen NM-L 42328 (Fig. 16C, F). The entire second half of the first whorl shows great irregularities in the course of growth lines and ribs. The apical part of the conch is smooth; very fine growth lines are discernible in the second quarter of the first whorl. The first faint ribs appear halfway through the first whorl. Later in ontogeny, they are again suppressed and the first pronounced rib is present at the beginning of the second whorl but fully developed ribs appear at $1 \frac{1}{5}$ of the whorl.

The described growth anomalies originated just after hatching (type a, b) or later in the first whorl (type c). Their position corresponds to an embryonic conch consisting of a single phragmocone chamber and body chamber. In summary, from 167 studied specimens of $O$. simplex with preserved early conch, in four specimens $(2.4 \%)$ have such anomalies been detected.

\section{Hatching indication inferred from shell morphology - summary}

A distinct transversal ridge or groove crossing the smooth apical part of $O$. simplex and located close to the first septum was formed inside the egg capsule (Figs 7B, C, 8A). It may correspond to the boundary between the muscular and non-muscular mantle in Nautilus (see Mutvei et al. 1993). This ridge has not been documented in O. rudens.

The abrupt change in coiling in $O$. simplex after the first quarter whorl probably indicates the end of the embryonic stage. This presumption is supported by the simultaneous location of change in sculpture, the sudden increased spacing of growth lines and the occasional presence of a dorsolateral groove. A similar change in coiling occurs in early nautilids, which was linked with hatching (Lechritrochoceratidae Flower, 1950, Turek 2010; Centroceratidae Hyatt, 1900 and Trigonoceratidae Hyatt, 1884, Shimansky \& Zhuravleva 1961). In all these cephalopods, it likely indicates the boundary between embryonic and postembryonic stages.

Changes in conch sculpture on the first whorl are likely

Figure 9. Early juvenile conchs of Ophioceras rudens Barrande, 1865 from Bohemia. A-E - Ludlow, Gorstian, N. nilsonni Zone; Praha-Butovice, F-Ludlow, Gorstian, Praha-Malá Chuchle; A-D, F, lateral views; E, ventral view. • A - NM-L 31922; marked change in sculpture at quarter of $1^{\text {st }}$ whorl (arrow) indicating hatching phase; spiral ridges appear near very apex. $\bullet$ B, E - NM-L 42311; B - dorsolateral groove linked with slight increase of spacing between growth lines is situated in sharp angle of dorsal side (dlg); E-shallow hyponomic sinus at the beginning of $2^{\text {nd }}$ whorl. $\bullet \mathrm{C}-\mathrm{NM}-\mathrm{L} 31921$; fine densely spaced growth lines pass rather gradually to widely spaced growth lines. Small defect in course of spiral ridges at half of $1^{\text {st }}$ whorl (arrow). - D - NM-L 42300; anomaly in course of conch axis (arrow) coincides with appearance of course sculpture. • F - NM-L 249, specimen illustrated by Barrande (1865) on pl. 45, fig. 5 ("O. tener"); densely spaced growth lines seen on almost entire apical part; arrow indicates change into more widely spaced growth lines (i.e. embryonic/juvenile conch boundary). Scale bars equal $1 \mathrm{~mm}$. 

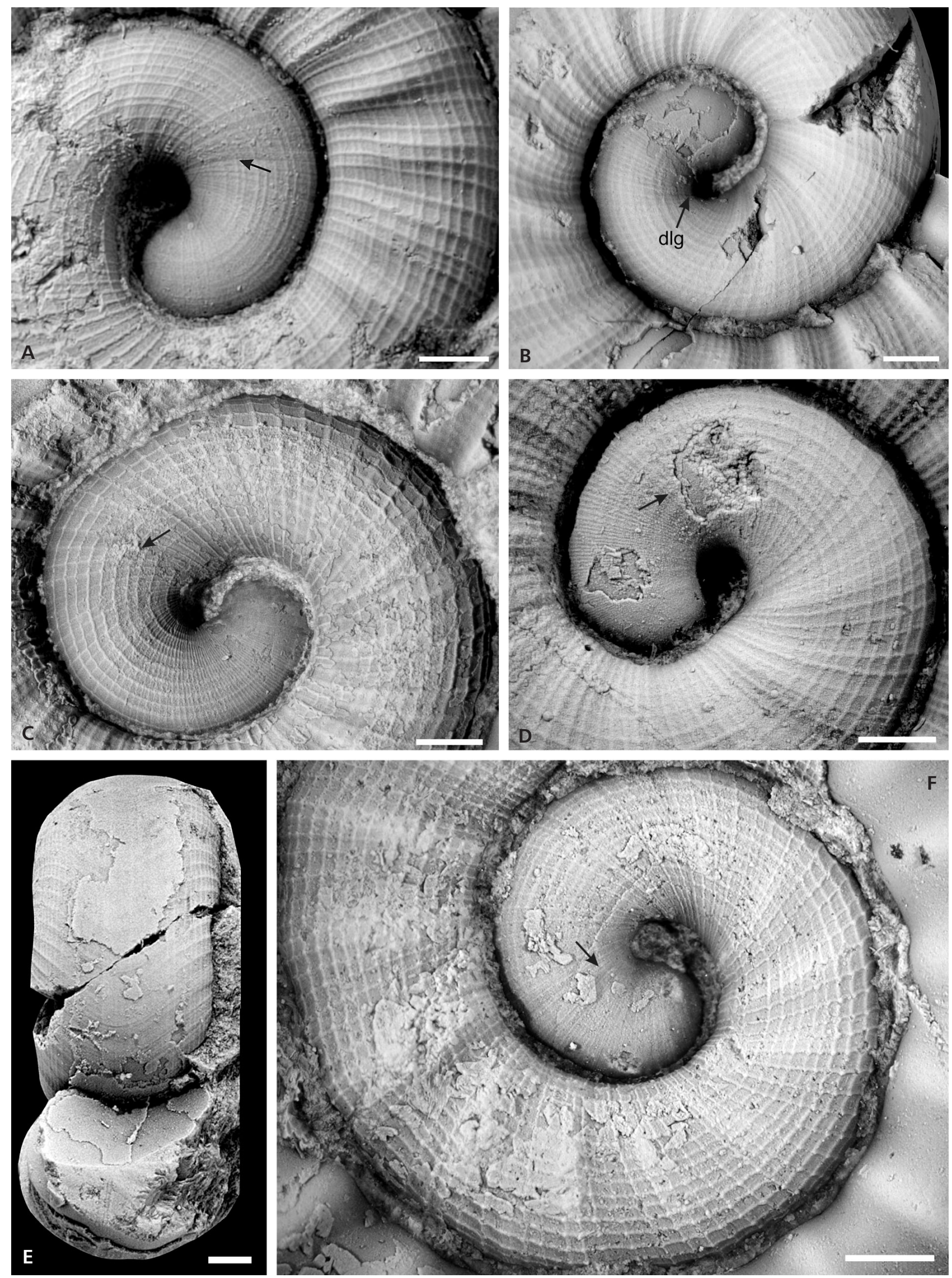
important for determining the time of hatching in Ophioceras. A sharp boundary between densely and widely spaced growth lines, located near the end of the first quarter whorl, is correlated with the beginning of the supposed post-hatching phase. Differences in orientation of transverse markings - growth ridges and ribs appearing close to the end of the first whorl - may improve structural integrity of the conch. Similarly, the spiral lirae in combination with growth lines forming a reticulate sculpture probably reinforced the small and fragile embryonic conch. Reticulate sculptures occurred in different evolutionary lineages including other cephalopod groups (e.g. orthocerids, ammonoids). It is characteristic of the embryonic stage of Nautilus (Stenzel 1964), as well as for some oncocerids, discosorids, tarphycerids (Barrande 1865, unpublished data) and Lechritrochoceratidae, i.e. the evolutionary oldest nautilids (Dzik \& Korn 1992, Turek 2010). However, in the Lechritrochoceratidae, similarly to Ophioceratidae, a reticulate sculpture appeared in the embryonic growth stage and persisted to maturity.

More elaborate sculpture coupled with the appearance of ribs can be a consequence of more intensive secretion of shell, i.e. raised metabolic activity of the organism after hatching. A positive correlation between sculpture development and original content of calcium carbonate in seawater is highly probable (Graus 1974, Vermej 1987, Manda \& Turek 2011). This is supported by the development of sculpture in specimens coming from different depth-related facies. Rib construction enhances strength and weight of the conch (Signor \& Brett 1984), but simultaneously, conch volume increases, thus influencing buoyancy. Nevertheless, development of ribs in Ophioceras is neither sudden, nor quite contemporaneous between individual specimens of the same species. The appearance of the first rib in Ophioceras usually does not coincide with the beginning of the post-embryonic stage.

Ribs are not common among tarphycerids (they also occur in Discoceras), but they are well developed in several of the earliest nautilids. In Silurian and Devonian Lechritrochoceratidae Flower, 1950 (in Flower \& Kummel 1950), the appearance of ribs coincides well with the supposed start of the post-embryonic stage and represents an analogy of the nepionic "constriction" (Turek 2010). This event is commonly expressed by the abrupt increase of the whorl expansion rate (Stenzel 1964, Chirat 2001). Similarly, in Devonian Centroceras Hyatt, 1884 and some Late Palaeozoic nautilids, ribs appeared immediately after hatching (Ruzhentsev \& Shimansky 1954).

Two carinae reinforcing the ventral side of Ophioceras appeared near the end of the first whorl i.e. in the post-embryonic stage. They may have been useful for mechanical protection of the immature, still tightly coiled conch, exposed to contact with the sea bottom in turbulent shallow waters. Eventually, it could be a result of fabricational noise from the deep hyponomic sinus and the neighboring ventrolateral projection (C. Klug, personal com.). Although a keel is common in Palaeozoic as well as in Mesozoic coiled nautiloids (see Frank et al. 2013), the bicarinate ventral side appeared for the first time in Ophioceras, and became more common in the Late Palaeozoic as well as younger coiled nautiloids (e.g., Barskov 1989, Westermann 1998).

The dorsolateral groove (nepionic constriction) of the early conch, more or less prominent in extant Nautilus, unequivocally indicates the end of the embryonic stage and hatching (e.g., Stenzel 1964, Arnold et al. 1987). Until now, a nepionic constriction has not been reported from any Early Palaeozoic nautiloid. Based on its morphology and location, it seems that an occasionally occurring groove in Ophioceras represents an analogous structure to the nepionic constriction in Late Palaeozoic and postPalaeozoic Nautilida.

Presence and development of a hyponomic sinus is useful to determine the point of hatching in extant Nautilus (Stenzel 1964), but it has very limited relevance in Ophioceras. It developed gradually in Ophioceras; no marked change in the deepness has been found near the supposed embryonic/postembryonic growth stages. We presume that juveniles reaching half whorl were able to swim efficiently, with further improvement in swimming ability in specimens reaching one full whorl.

The internal structures of juvenile conch such as changes in siphuncle position and in septal spacing have been considered to determine the end of the embryonic phase in Ophioceras. The position of the siphuncle appears to be a feature important for the ecology of the animal. It influenced the efficiency of water and gas-exchange in the phragmocone (Chamberlain \& Pillsbury 1985). In Nautilus, the position of the septal foramen does not change substantially throughout ontogeny. By contrast, in tarphycerids and lechritrochoceratids, the siphuncle changes its position within the first four chambers until it reached its final location. A distinct shift of the siphuncle may happen either within the egg capsule or post-embryonically. In Ophioceras, the siphuncle reaches its final position in the second septum. Our data suggest that the second phragmocone chamber was possibly formed after hatching. Change in the siphuncle position is a valuable tool for tracing the evolution of tarphycerids, but not to estimate when they hatched.

Concerning septal spacing, septal crowding is interpreted as a sign of deceleration of growth in Nautilus, e.g., as reaction of the organism to the post egg capsule environment or near maturity. Conchs of Nautilus hatchlings reached $1 \frac{1}{4}-1 \frac{1}{2}$ whorls (Stenzel 1964, Arnold et al. 1987, Mutvei et al. 1987, Chirat \& Rioult 1998, Chirat 2001). To interpret the change in septal spacing with respect to hatching in Ophioceras, its embryonic conch would reach about 
$1 \frac{1}{4}$ whorls (usually 8 chambers plus the body chamber, which, in the youngest specimens attains about $1 / 4$ whorl). The mode of early ontogeny in Nautilus does not correspond well with the conditions in Ophioceras; except for the similarity in septal spacing, other morphological features indicating hatching in Ophioceras (sudden change in conch coiling, sudden increase in growth line spacing, frequent appearance of fine longitudinal ridges on the first quarter whorl forming a reticulate sculpture, dorsolateral grove, ontogenetically earliest healed injuries) demonstrate that the first septal approximation was formed differently than in Nautilus. The question is whether closely spaced septa at the beginning of the second whorl really reflect deceleration of conch growth. There is no reason to reject this presumption if we take the forward shift of the aperture due to accretionary growth into account. However, absolute growth rates in Nautilus correspond to size or weight increasing with time (Chirat et al. 2008). In Ophioceras, near the end of the first whorl, fully developed ribs appear on the conch surface. The appearance of ribs coincides with a markedly thickened conch wall and considerably enlarged surface of the conch. Ribs thus indicate that the utilization of $\mathrm{CaCO}_{3}$ continued with a more or less increased intensity. While growth lines near the aperture of fully-grown and thus slowly growing specimens are very densely spaced, no difference in distance between individual growth lines (lirae) was observed near the beginning of the second whorl.

There is also another potential cause of the distance between the $7^{\text {th }}$ and $9^{\text {th }}$ phragmocone chambers. Commonly, their position coincides with the end of the first whorl. Conch shapes of the first and second whorl differ and consequently, a change in septal spacing in Ophioceras could be linked with this conch shape modification. Due to tight coiling, an imprint zone developed at the beginning of the second whorl, and conch shape changed. As a consequence, in response to conch shape change, the animal formed more densely spaced septa. However, the marked shortening of phragmocone chambers in the first whorl frequently occurring in tarphycerids may have another cause. It may indicate the time when juveniles possessing probably a buoyant phragmocone with two, three or five to eight

Figure 10. Early juvenile conchs - sculpture and hyponomic sinus in Ophioceras simplex (Barrande, 1855) from Bohemia; A, B - ventral views; C, D - lateral views. • A, C - NM-L 42337; Ludlow, Ludfordian; Praha-Lochkov; $\mathrm{A}-\mathrm{at}^{3} / 4$ of $1^{\text {st }}$ whorl, wide and shallow hyponomic sinus passes into deeper and narrower one, with simultaneous development of bicarinate ventral side; $\mathrm{C}$ - sharp border between smooth apical part and striated adjacent part of conch; longitudinal lirae quite suppressed. - B, D - NM-L 28709; late Ludlow or earlier Př́idolí; Praha-Lochkov or Kosoř; B - well developed hyponomic sinus at the end of $1^{\text {st }}$ whorl; D - location of dorsolateral constriction (dlc) coincides with marked change in sculpture at boundary between supposed embryonic and postembryonic stages. Scale bars equal $1 \mathrm{~mm}$.
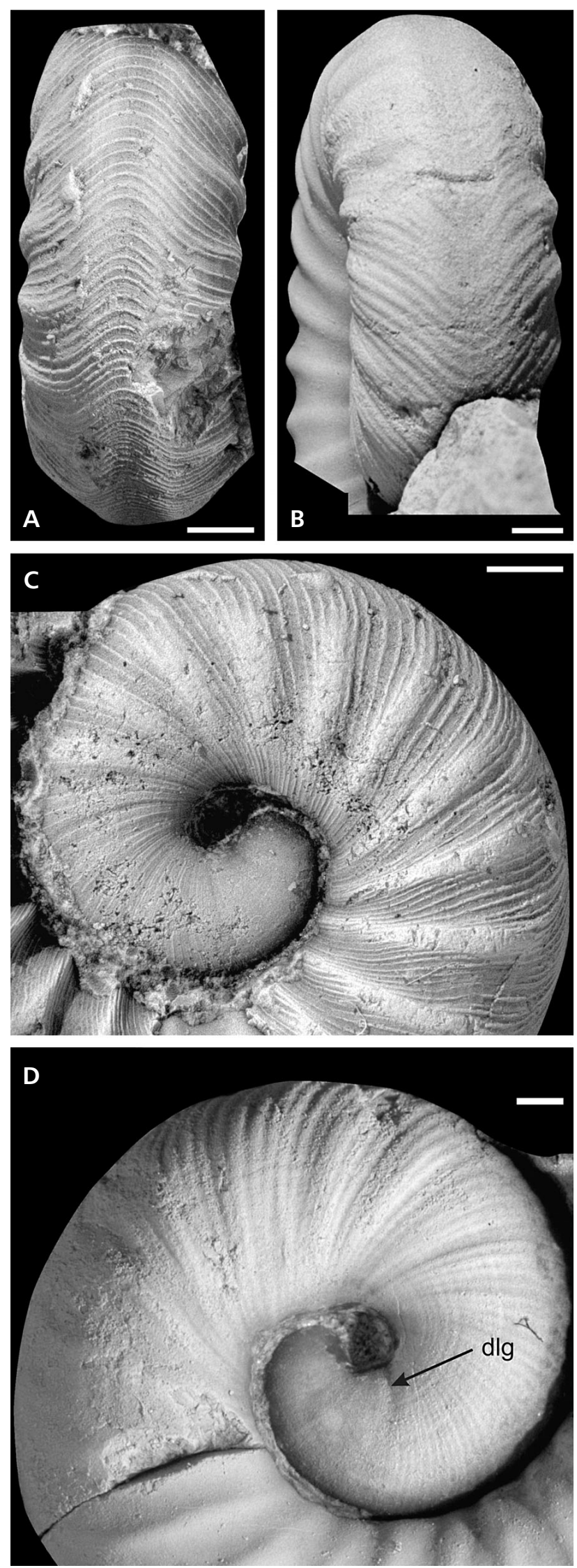
phragmocone chambers (Shimanski \& Zhuravleva 1961) descend from the surface to deeper and colder water. Such an explanation better fits Curtoceras eatoni (Whitfield, 1886) (Furnish \& Glenister 1964, p. K360), C. teres (Eichwald, 1840) and Estonioceras imperfectum (Wahlenberg, 1821) (Stumbur 1959), in which a change in septal spacing between the $6^{\text {th }}$ and $7^{\text {th }}$ septum preceded the stage in which the conch reached one full whorl. Based on their study of Jurassic nautilids, Chirat et al. (2008, p. 259) considered the most proximate cause of modification in septal spacing "in the scaling relationship between the overall weight increase of the animal relative to angular length of conch added to the aperture".

Anomalous growth and repaired conch damage appearing in early juvenile conchs are used as an important tool for the determination of the end of the embryonic phase (Stenzel 1964, Arnold et al. 1987, Chirat 2001). The ontogenetically earliest damages in Ophioceras appear at about the first quarter whorl. Their locations correspond well to the post-hatching phase supposed on the basis of other morphological features mentioned above. They comprise depressions of various depth and outline. For comparison, conchs of Nautilus typically have conch breakages with wavy or v-shaped edges found on and located close to the nepionic constriction (Arnold et al. 1987, Yomogida \& Wani 2013), but such damage has not been found in Ophioceras. The rarity of fossils showing sublethal damages in early juvenile conchs of Ophioceras might be related to the higher mortality from predatory attacks (Yomogida \& Wani 2013) or of the supposed planktonic habit of juveniles; conchs of demersal juveniles of Early Palaeozoic nautiloids possess healed injuries more frequently (authors, unp. data). Rareness of serious healed damage in late juvenile growth stages in Ophioceras is probably linked to solid conch reinforced by prominent transversal ribs and the presence of carinae. Repeated damage in the above-mentioned specimens may reflect lower fitness of the animal in life (in one specimen, there is also a pit, interpreted below as a reaction to a parasite infestation). The cause of all injuries documented in this paper is interpreted as a bite, probably by some other cephalopods, eurypterids or phyllocarids (Brett 2003, Kröger 2004). The ventral and lateral surfaces of the conch wall were the strongest in Ophioceras; the ribs were less-well developed on the umbilical slopes; this may explain why predators selected this unusual and not easily accessible dorsolateral location on the conch for an attack.

\section{Anomalous conch growth in late-juvenile and pre-mature stages}

Attention has been paid also to growth anomalies occurring in late-juvenile and premature conchs of Ophioceras for comparison with anomalies present on conchs that occurred soon after hatching. Healed conch injuries, anomalous septa and pits occurring in different growth stages are still poorly documented in nautiloids (Keupp 2012), despite the fact that they could offer valuable data for the autecology of cephalopods (DeBaets et al. 2015).

\section{Healed injuries}

Healed injuries observed in late juvenile and pre-mature specimens of Ophioceras are similar to injuries reported in Nautilus and other cephalopods with external conchs (Mapes \& Chaffin 2003, Klug 2007, Slotta et al. 2011, Ymogida \& Wani 2012). They include both minor damage (at millimeter scale) and serious damage (affecting a significant portion of the aperture). Detection of the occurrences of these injuries is negatively influenced by preservation, especially partial exfoliation of conchs, particularly on the body chamber.

Minor damage expressed especially in the anomalous course of transversal growth lines or ridges are relatively common in O. simplex (e.g., specimens NM-L 42322, Fig. 6A, and NM-L 42293, Fig. 17B). The damages affected a narrow zone along the thin and fragile aperture margin, usually without any adverse influence on further conch formation.

Healed conch damage corresponding to extensive damage to the former aperture and mantle margin has been discovered in Ophioceras only exceptionally. Traces of healed sublethal damages situated laterally were found in

Figure 11. Septal spacing in early juvenile conchs of Ophioceras simplex (Barrande, 1855) from Bohemia; all lateral views of internal moulds. -A - NM-L 42266; Ludlow, Ludfordian, S. linearis Zone; Beroun-Dlouhá hora; specimen showing moderate shortening of $8^{\text {th }}$ chamber; following chambers in this and other cases also short, their lengths slowly increased with further growth. • B - NM-L 31870, late Ludlow, vicinity of Prague. Marked shortening of the $7^{\text {th }}$ chamber; note also the course of two earliest ribs on $4^{\text {th }}$ and $5^{\text {th }}$ chambers which are almost transversal (comp. Fig. $11 \mathrm{~F}$ ); due to affection of dorsolateral part of conch by parasite (arrow), two ribs are here markedly shortened. $\bullet$ C - NM-L 42251; late Ludlow, vicinity of Prague; shortening of $8^{\text {th }}$ and especially $9^{\text {th }}$ chambers. $\cdot D-N M-L 42317$; late Ludlow, vicinity of Prague; internal mould with damaged $1^{\text {st }}$ chamber, slight shortening of $7^{\text {th }}$ and moderate shortening of $8^{\text {th }}$ chambers; ribs discernible starting with half of $1^{\text {st }}$ whorl (gr). $\bullet$ E - NM-L 42302; Ludlow, Ludfordian, S. linearis Zone; Beroun-Dlouhá hora moderate shortening of $8^{\text {th }}$ chamber. $• F-$ NM-L 31897 ; late Ludlow or earlier Přídolí; Praha-Lochkov or Kosoř; moderate shortening of $8^{\text {th }}$ chamber and marked shortening of $9^{\text {th }}$ chamber. Notice also differences in course of ribs on $6^{\text {th }}-8^{\text {th }}$ and $10^{\text {th }}$ and following chambers. Scale bars equal $1 \mathrm{~mm}$ except $11 \mathrm{~B}(5 \mathrm{~mm})$. 

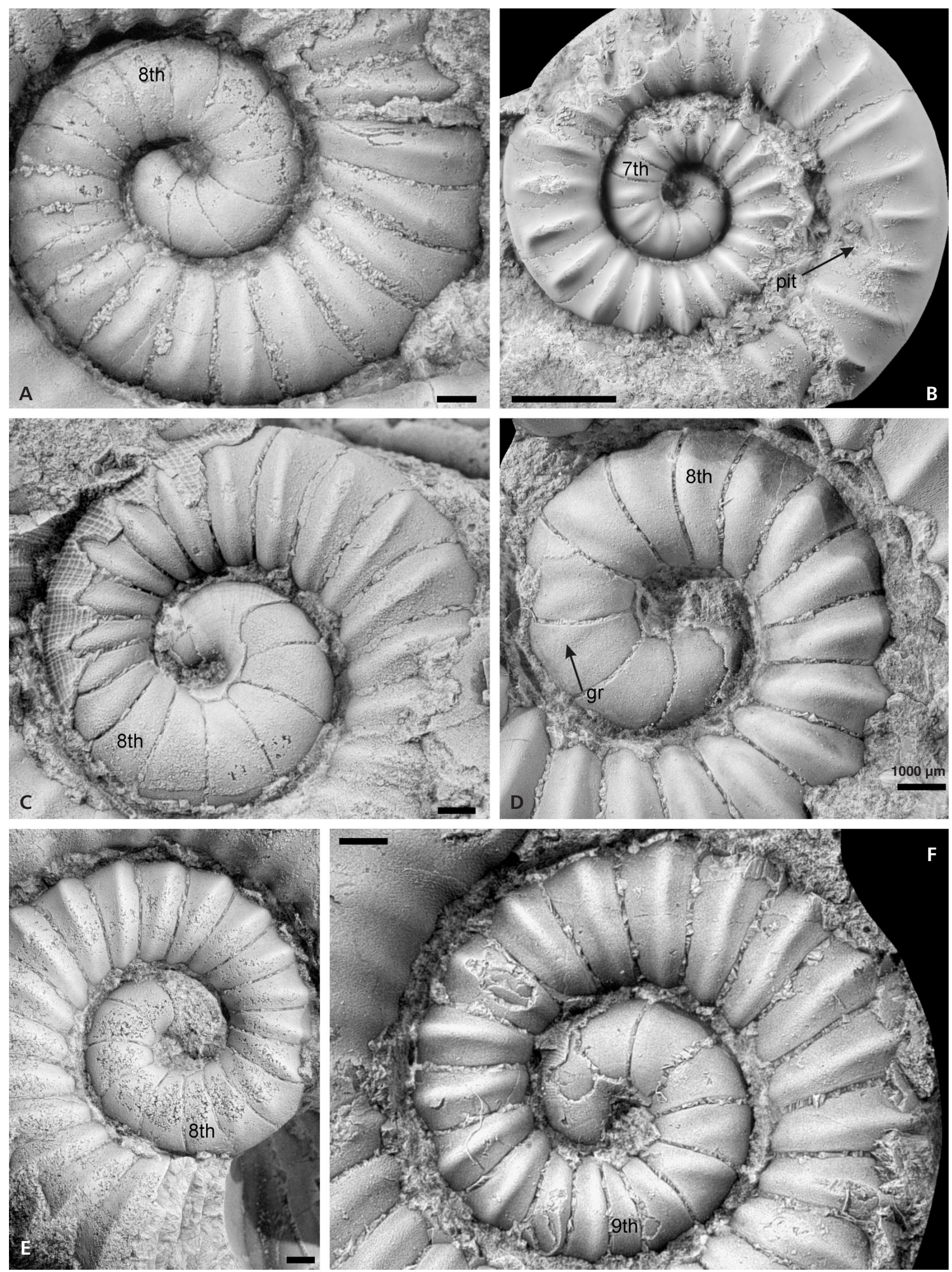

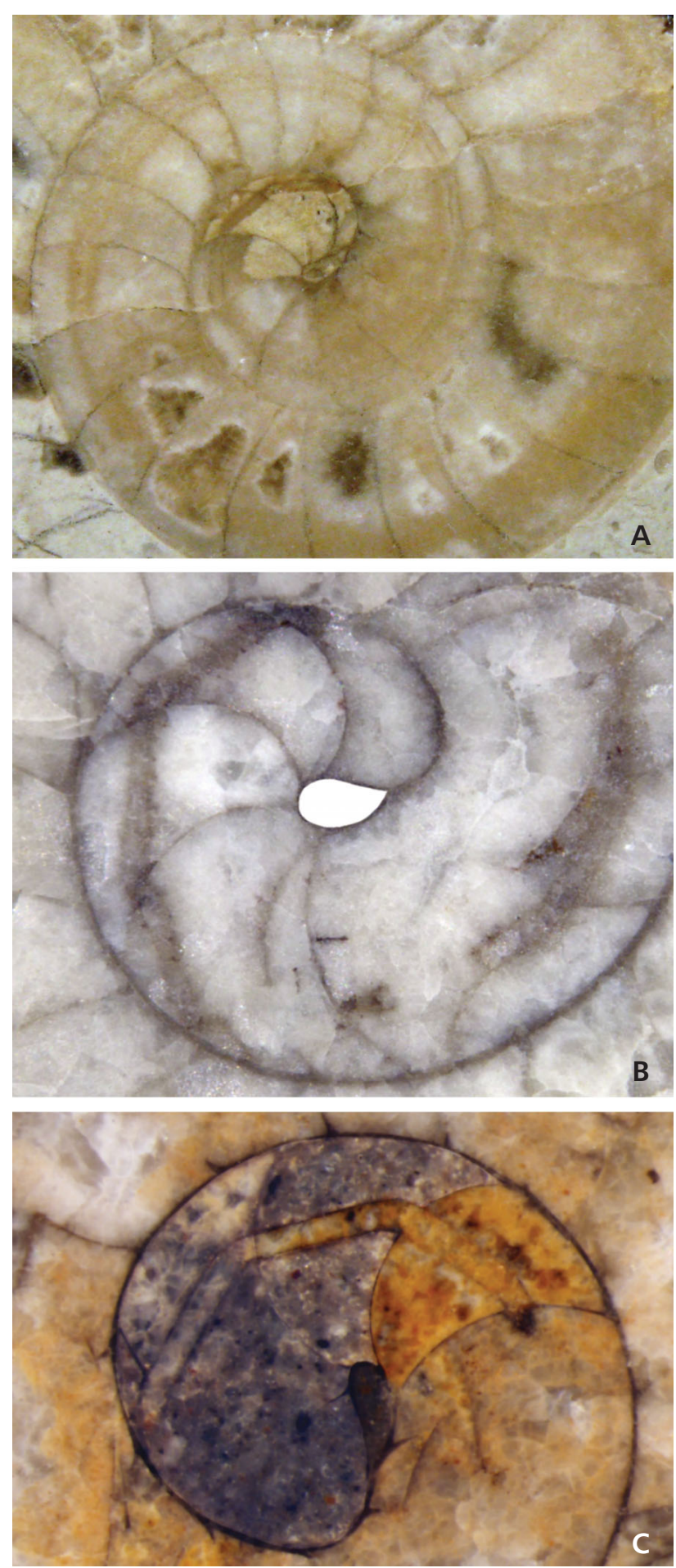

Figure 12. Internal structure of embryonic and juvenile phragmocones in Ophioceras simplex (Barrande, 1855) (A, B) and O. rudens Barrande, 1865 (C); all polished median sections. • A - Mo 59120, Specimen illustrated by Linström (1890, pl. 7, figs 23, 24: O. reticulatum); Wenlock; Samsugn, Othem, Gotland, Sweden; notice straight dorsal side in first three chamber and very short $1^{\text {st }}$ chamber, $\times 4$. $\bullet B-$ NM-L 42349; late Ludlow, Ludfordian, P. fragmentalis Zone (P. archiaci-A. modesta Community); Beroun, Kosov Quarry, Bohemia; notice long dome-shaped $1^{\text {st }}$ chamber; siphuncle partly damaged, ×7.5. • C - NM-L 28696; Ludlow, Gorstian, N. nilsonni Zone; Praha-Butovice, Bohemia; preserved siphuncle in first four chambers, $\times 10$. two specimens. In one specimen, such instances of damage occur twice in close proximity to each other (Fig. 17F, NM-L 43159); in another, such damage occurs six times (Fig. 17A, D, E; NM-L 29065).

A remarkable case of sublethal conch damage in the dorsolateral part of the conch was discovered in three specimens of $O$. simplex. In specimen NM-L 42289 (Fig. 5F) at about $1 \frac{3}{4}$ whorls, a distinct repaired injury appears dorsolaterally. A deep and narrow spiral grove is completely healed before the beginning of the third whorl. Growth lines take the form of an adapically-directed "V". With further growth, the "V" formed by growth lines became broader and shallower. By the end of the second whorl, the course of growth lines is back to normal. The same kind of healed injury situated dorsolaterally at $1 \frac{1}{4}$ and $1 \frac{1}{2}$ whorls is present in specimen NM- L 42284 (Fig. 5C). Due to exfoliation of the conch more adaperturally, complete repair of this injury cannot be observed. Another similar prominent injury situated dorsolaterally is present in specimen NM-L 43159 (Fig. 17G). In all these cases, the mode of reparation of the conch indicates that not only the aperture was locally damaged, but the mantle epithelium was also affected.

\section{Anomalous growth of ribs}

The shape of fully developed ribs, after their appearance on the conch, i.e. usually at the end of the $1^{\text {st }}$ whorl, is rather uniform. While the first ribs are frequently rursiradiate, their course roughly corresponds to that of the sutures after the end of the first whorl. Usually, one rib per chamber is developed. Near the aperture of fully grown specimens, ribs are usually less prominent, in some cases vanishing completely. However, anomalous shapes and/or courses of ribs have been found in about $2 \%$ of specimens. In such cases, ribs are markedly shortened, their course is interrupted, they are ventrolaterally abruptly curved adapically, or anastomosis between two adjacent ribs is developed (Stridsberg \& Turek 1997, fig. 9F; 11B, 18C, F herein).

\section{Anomalous course of suture}

Sutures of Ophioceras are moderately convex, forming laterally almost symmetrical lobes. In three specimens of O. simplex, serious anomalies in the course of septa have been observed. Moderately vaulted septa are replaced by a few highly convex septa, and distances between neighboring septa markedly increased. In specimen NM-L 43161 (Figs 17C, 18D), growth of two septa at the beginning of the last whorl was affected by a laterally situated, longitu- 

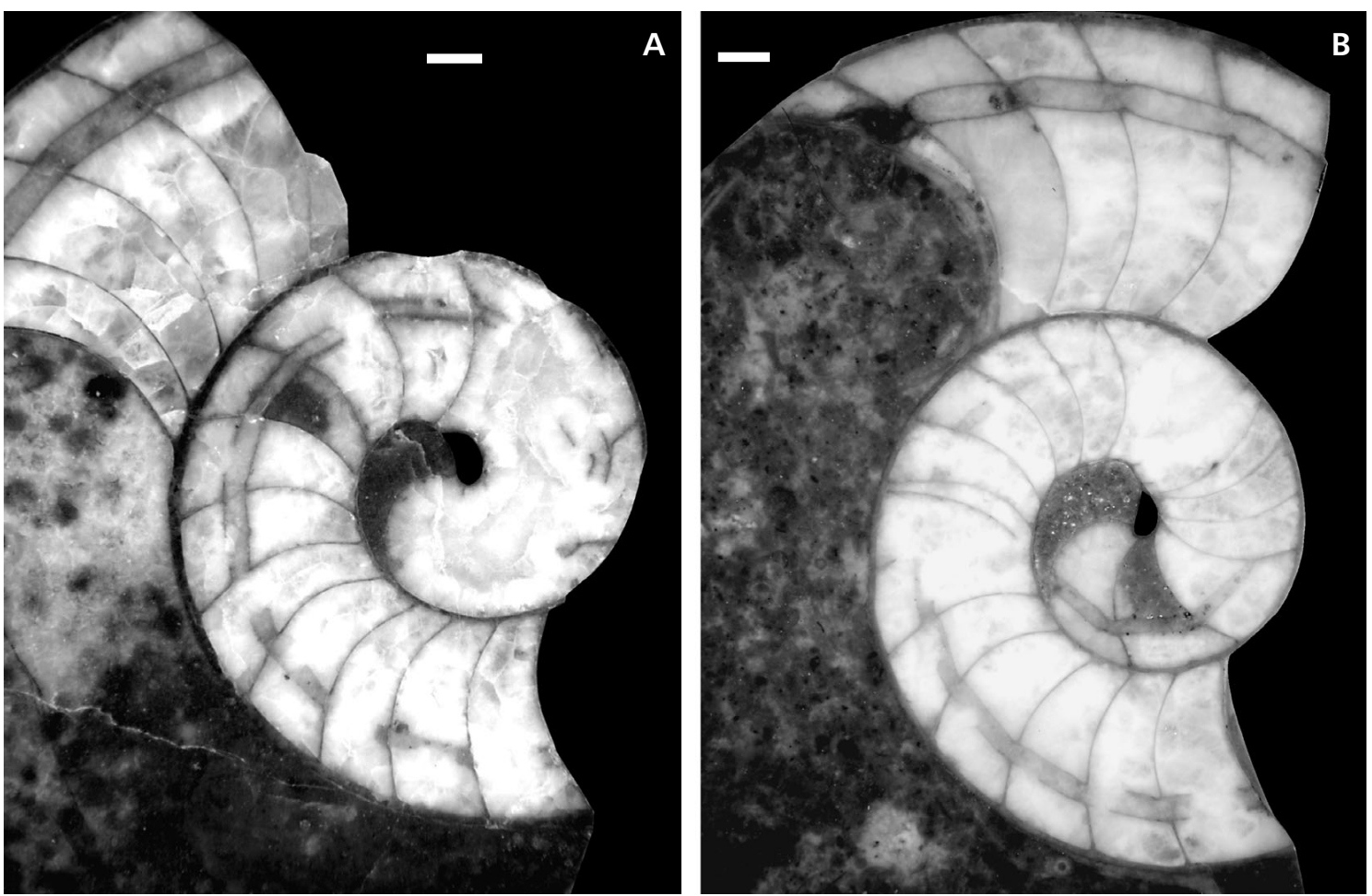

Figure 13. Internal structure of the phragmocone in Ophioceras simplex (Barrande, 1855) from Bohemia; polished median sections. $\bullet$ A - NM-L 42348, late Ludlow or earlier Přídolí; Praha-Lochkov or Kosoř; long dome shaped $1^{\text {st }}$ chamber (filled by sediment). • B - NM-L 42250, Ludlow, Praha-Velká Chuchle; notice angular shape of $1^{\text {st }}$ chamber (filled by sediment), especially straight dorsal side and area of cicatrix. Scale bars equal 1 mm.

dinally extending growth anomaly. The internal mould of the first of the two unusually long phragmocone chambers, adapertural to these two septa, has a deep furrow. The furrow, however, already appears in the preceding two chambers. Following the growth anomaly, the septa are again almost symmetrical, moderately vaulted. Specimen NM-L 43162 shows a similar course of two sutures - the third and fourth (counted from base of body chamber). In specimen NM-L 28694 (Stridsberg \& Turek 1997, fig. 10e), the anomalous course of sutures, forming a minor lobe on the umbilical shoulder can be observed in the third to fifth sutures.

\section{Pits on internal moulds: parasite/epizoan infestation}

One to five irregularly distributed pits sometimes occur on internal moulds of Ophioceras body chambers (Stridsberg \& Turek 1997, figs 9i, 10c; Figs 11B, 18A-I herein). They have been found in 21 specimens of Ophioceras simplex $(=3.9 \%, \mathrm{~N}=536)$ and in one specimen of $O$. rudens $(=3 \%$, $\mathrm{N}=33$ ). Pits are located mostly in the adapical half of the body chambers of mature or premature specimens; no pit has yet been found in early juvenile stages of Ophioceras. All studied specimens with pits come from the Ludlow and
Přídolí of Bohemia. The depressions, of varying deepness, size and morphology are situated laterally, ventrolaterally, dorsolaterally and ventrally. They are distributed either irregularly or in rows, their outline is subcircular, elliptical or irregular, and their diameter varies between 1.5-3 mm. The pits are sometimes very shallow and hardly discernible, in other cases they form deep crater-like depressions (2-3 mm) with steep sides. Wrinkles or very small dots have been occasionally found on the surface and on the periphery of the largest pits (NM-L 31869, Fig. 18A). In some cases, shell remains are preserved inside of the pits or on their sides (NM-L 28704, Fig. 18B, E; NM-L 31865, Fig. 18I). However, due to conch exfoliation of the body chamber and recrystallization of the shells, it is impossible to study the internal structure of the conch wall in the area of the pits. Pit occurrences are linked to some growth abnormalities affecting the growth of ribs (NM-L 31870, Fig. 11B; NM-L 31919, Fig. 18C), and eventually sutures (NM-L 43161, Fig. 17C). Wrinkles and dots on the surface of internal moulds of the pits reflect local anomalies in nacre secretion.

Relics of the conch wall occurring close to the periphery of the pits or in their bottoms as well as the mode of preservation of similar pits in Peismoceras asperum (Barrande, 1865) (Turek \& Manda 2010, fig. 2d) offer evidence that at least some pits on internal moulds correspond 


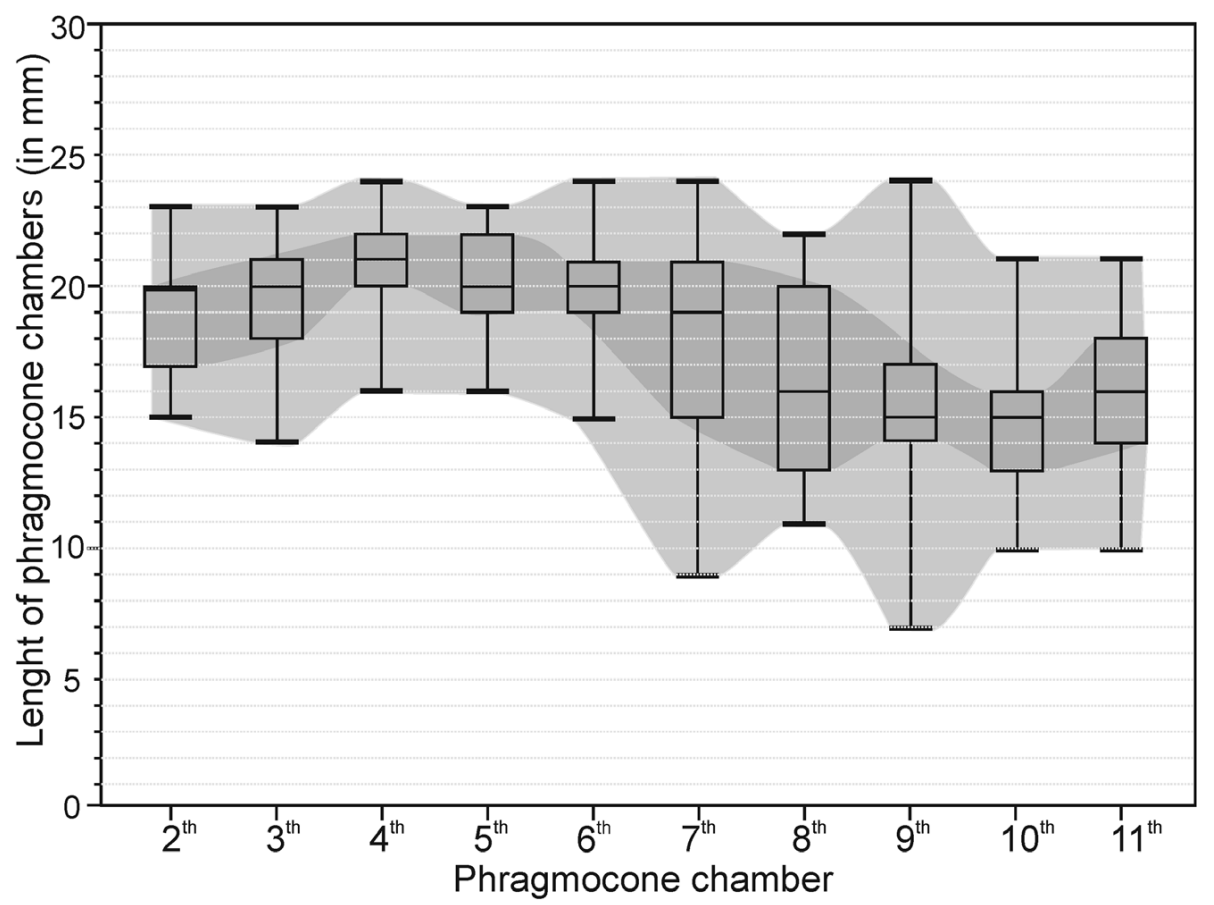

Figure 14. Boxes illustrating changing length of phragmocone chambers 2-11 in Ophioceras simplex (minimum, quartile 0.25 , median, quartile 0.75 and maximum, for data see Table 4). to crater-like depressions on the outer conch surface. Pits in Ophioceras in this regard thus resembles smaller pits in the Late Jurassic ammonoid Kachpurites Spath, 1923 in which conch layers in the pits are bent downward without changing in thickness (Mironenko, in press). Some pits, especially the deeper ones, may correspond to blister pearls located on the inner surface of the conch wall (Keupp 2012; De Baets et al. 2011, 2015). However, relationship of these pits to the blister pearls cannot be proved, due to absence of intact shell material in place of pits. Similar pits, probably of the same origin, have been reported also in some other Silurian nautiloid genera i.e. in Peismoceras Hyatt, 1894 (Turek \& Manda 2010, fig. 2), Kosovoceras Turek, 1975, Boionautilus Turek, 2008 (unpublished data), and Pomerancoceras Kröger, 2007 (Manda \& Turek 2009b, figs 9, 10). Nevertheless, such pits are present in nautiloids rather infrequently, and have not yet been reported from discosorids, orthocerids or pseudorthocerids, nor in Devonian nautiloids.

So-called "Housean pits" documented from some Devonian ammonoids (House 1960; Chlupáč \& Turek 1983; De Baets et al. 2011, 2015) differ from the pits seen in nautiloid conchs by their morphology, size, and arrangement. In the Devonian ammonoids, longitudinally elongated pits (in the direction of growth) are frequently arranged in spirals, or are round in outline, situated almost radially; occasionally, they can be chaotically arranged. Pits in ammonoids are generally much smaller and much more numerous in individual specimens compared to nautiloids. There is no order in the positions of pits in Ophioceras and other nautiloids. Only in a few cases, two to four pits differing in size and depth are arranged in a row. While in Devonian ammonoids the pits correspond to raised conch projections on the inner shell wall and the conch surface shows its usual character (House 1960; De Baets et al. 2011, 2015), the conch surface displays remarkable abnormalities in Ophioceras. Pits in some cases distort ribs and change their course (Fig. 18C, D, F, G, I; Turek \& Manda 2010, fig. 2d). A characteristic example of anomalous growth of the last rib near the aperture of fully grown specimens of $O$. simplex is visible in the specimens NM-L 43158 (Fig. 18F). Exceptionally found anomalous growth of septa in Ophioceras (Figs 17C, 18D) is also accompanied by pits on the conch or possibly pearls. Similar anomalous septa coupled with pits were described from the Silurian oncocerid Pomerantsoceras pollux (Barrande, 1866) (Manda \& Turek 2009b).

Nevertheless, despite the differences between pits in nautiloids and ammonoids, their formation in both groups can be linked with a parasite/epizoan infestation. Parasites penetrated between the conch and mantle margin, and caused anomalous conch growth at the aperture in ammonoids (De Baets et al. 2015) and speculatively, the same had happened in Ophioceras. However, the local deformation of conch could also cause epizoa, or be a result of bacterial infection (Mironenko, in press). According to his new interpretation, pits in Jurassic ammonite Kachpurites Spath, 1923 (except one, most likely corresponding to pearl) "had been formed by epifauna located at a flexible uncalcified part of the periostracum in the apertural region of the growing ammonite shell" (Mironenko, in press). Anomalous growth of septa in Ophioceras, accompanied 

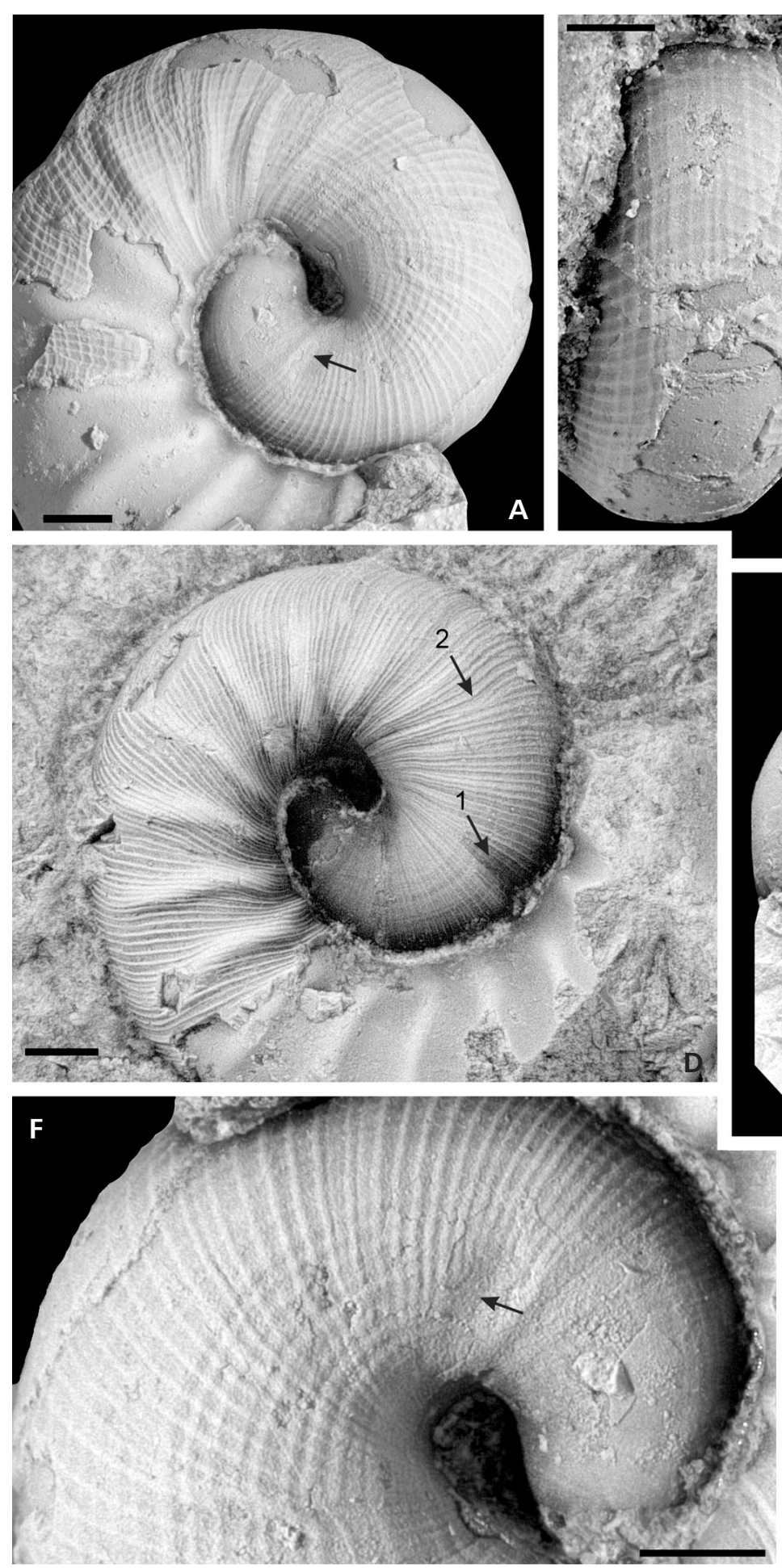
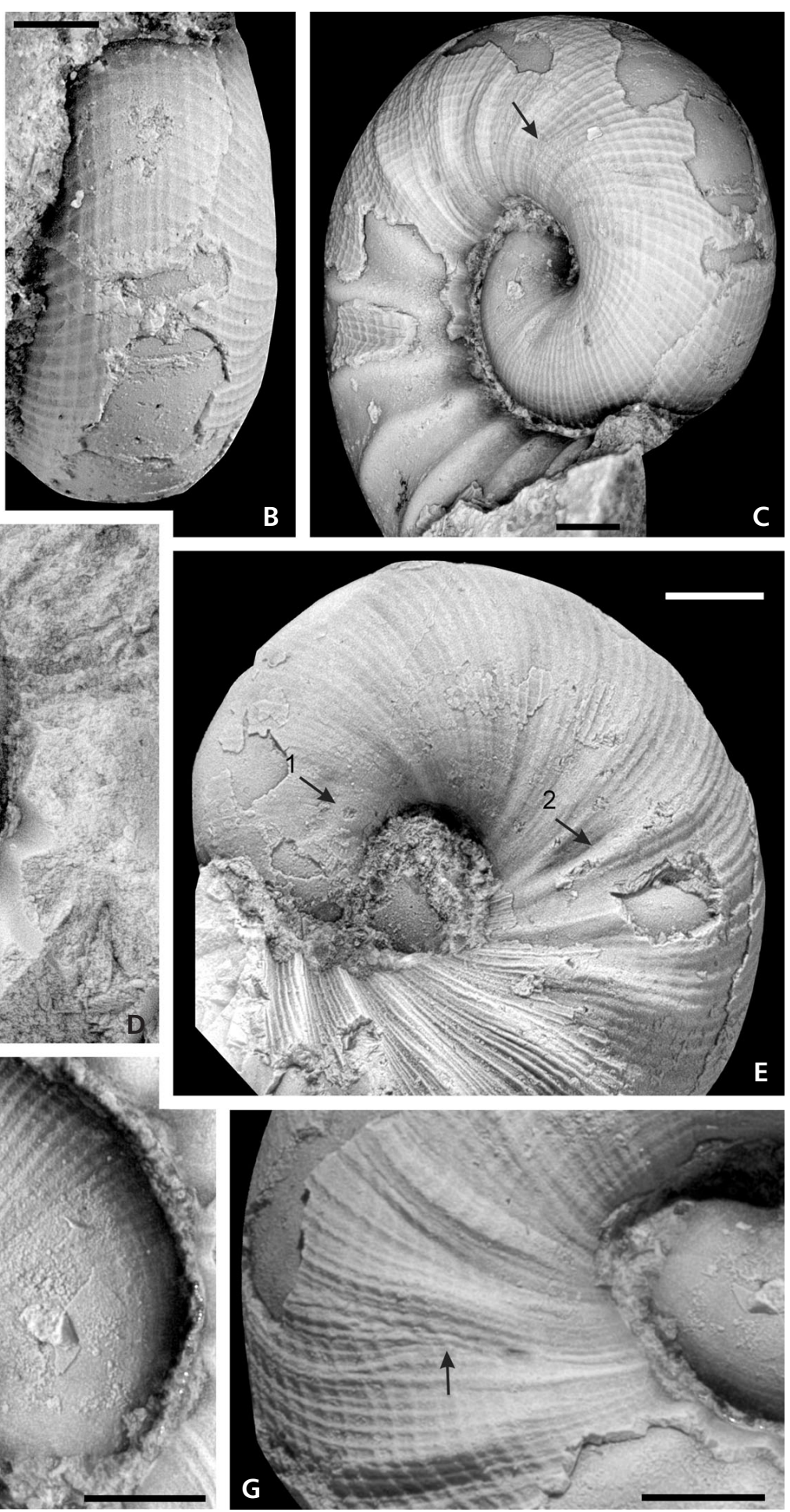

Figure 15. Anomalous growth of early juvenile conchs of Ophioceras simplex (Barrande, 1855) from Bohemia. • A-C, F, G - NM-L 42298; Ludlow, Ludfordian, N. inexpectatus Zone; Všeradice Section, bed No. 4 (Manda et al. 2012); A - lateral view; growth anomaly - shallow depression situated dorsolaterally on early juvenile growth stage (arrow), fully developed ribs and marked irregularities in course of growth lines at the end of $1^{\text {st }}$ whorl; $\mathrm{B}$ - ventral view; shallow hyponomic sinus at midpoint of $1^{\text {st }}$ whorl (top of the picture); $\mathrm{C}$ - anterolateral view; $\mathrm{F}$ - detail of first growth anomaly; $\mathrm{G}$ - small repaired damage at the beginning of $2^{\text {nd }}$ whorl. $\bullet$ D - NM-L 46510; late Ludlow or earlier Príídolí, Praha-Lochkov, Orthoceras quarry; deep transversally elongated depression situated ventrolaterally (arrow 1) and irregularities in course of growth lines appearing later (arrow 2). E - NM-L 42333; Ludlow, Ludfordian; vicinity of Prague; left lateral view; shallow depression situated sinistrally at quarter of $1^{\text {st }}$ whorl (arrow 1), another depression (arrow 2) prolonged transversally (in course of growth lines) placed laterally at about end of $1^{\text {st }}$ whorl. Scale bars equal $1 \mathrm{~mm}$. 

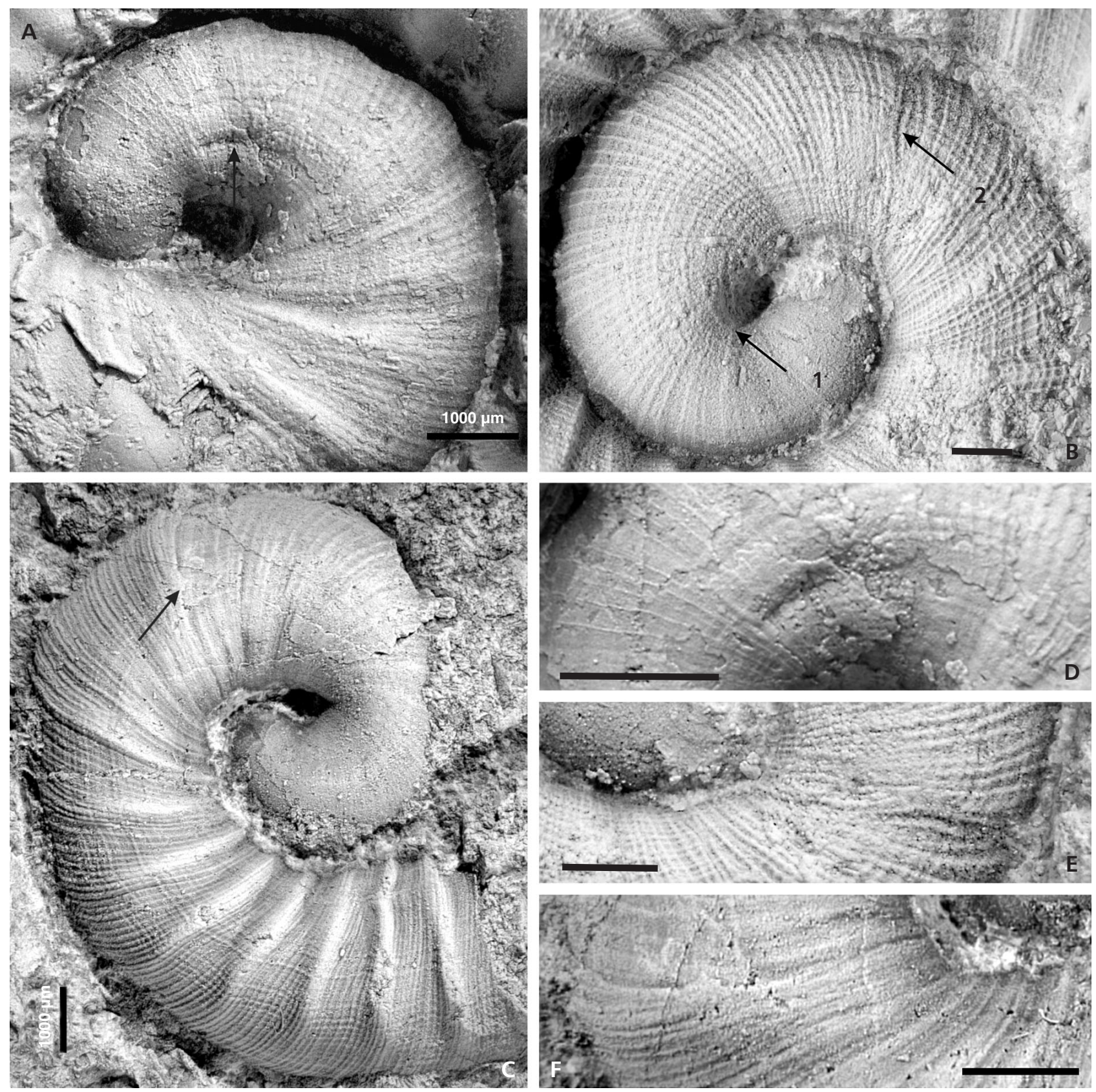

Figure 16. Anomalous growth of early juvenile conchs of Ophioceras simplex (Barrande, 1855) from Bohemia; all lateral views. • A, D - NM-L 42310; late Ludlow or ealier Př́dolí, Praha-Kosoř or Lochkov; A - deep V-shaped depression situated laterally disappears at $1 / 2$ of $1{ }^{\text {st }}$ whorl, where well-developed ribs appear laterally; D - detail of injury. • B, E - NM-L 42312; Ludlow, Ludfordian, S. linearis Zone; Beroun-Dlouhá hora; dorsolateral groove at the end of embryonic stage, at point of marked change in conch coiling (arrow 1); note also sudden expansion of conch resulted in very narrow umbilical perforation; small growth anomaly at the end of 1st whorl (arrow 2). $\bullet$, F - NM-L 42328; Ludlow, Gorstian; Reporyje-Ohrada; C - anomalous growth of whole second half of $1^{\text {st }}$ whorl (note marked irregularities in course of growth lines and development of ribs); $\mathrm{F}$ - detail of sculpture at end of $1^{\text {st }}$ whorl. Scale bars equal $1 \mathrm{~mm}$.

Figure 17. Healed conch damage and anomalous growth in different growth stages of Ophioceras simplex (Barrande, 1855) from Bohemia; all lateral views. - A, D, E - NM-L 29065; Ludlow, probably Beroun-Dlouhá hora; complete conch (A) and details of healed injuries in last whorl (D, E) indicated by arrows. - B - NM-L 42293; late Ludlow or earlier Př́ídolí; Praha-Lochkov or Kosoř; minor conch damage situated laterally at the beginning of third whorl (arrow). - C - NM-L 43161; late Př́ídolí, M. transgrediens Zone; Karlštejn; anomalous growth of septa; note that pronounced lobe of suture has relationship with furrow on last whorl (arrows 1, 2); imprints of palliovisceral ligaments originated on body chamber (arrow 2); complete conch on Fig. 18D. • F, G-NM-L 43159; Ludlow, Ludfordian, S. linearis Zone; Zadní Kopanina or Kosov locality, complete conch with healed conch damage in $3^{\text {rd }}$ whorl indicated by arrows $(\mathrm{F})$ and detail of early conch with repaired dorsolateral injury marked by arrow (G). Scale bars equal $1 \mathrm{~mm}(\mathrm{~B}-\mathrm{E}, \mathrm{G})$ and $5 \mathrm{~mm}(\mathrm{~A}, \mathrm{~F})$. 
Vojtěch Turek \& Štěpán Manda • Early ontogeny, anomalous growth, and healed injuries in the Silurian nautiloid Ophioceras
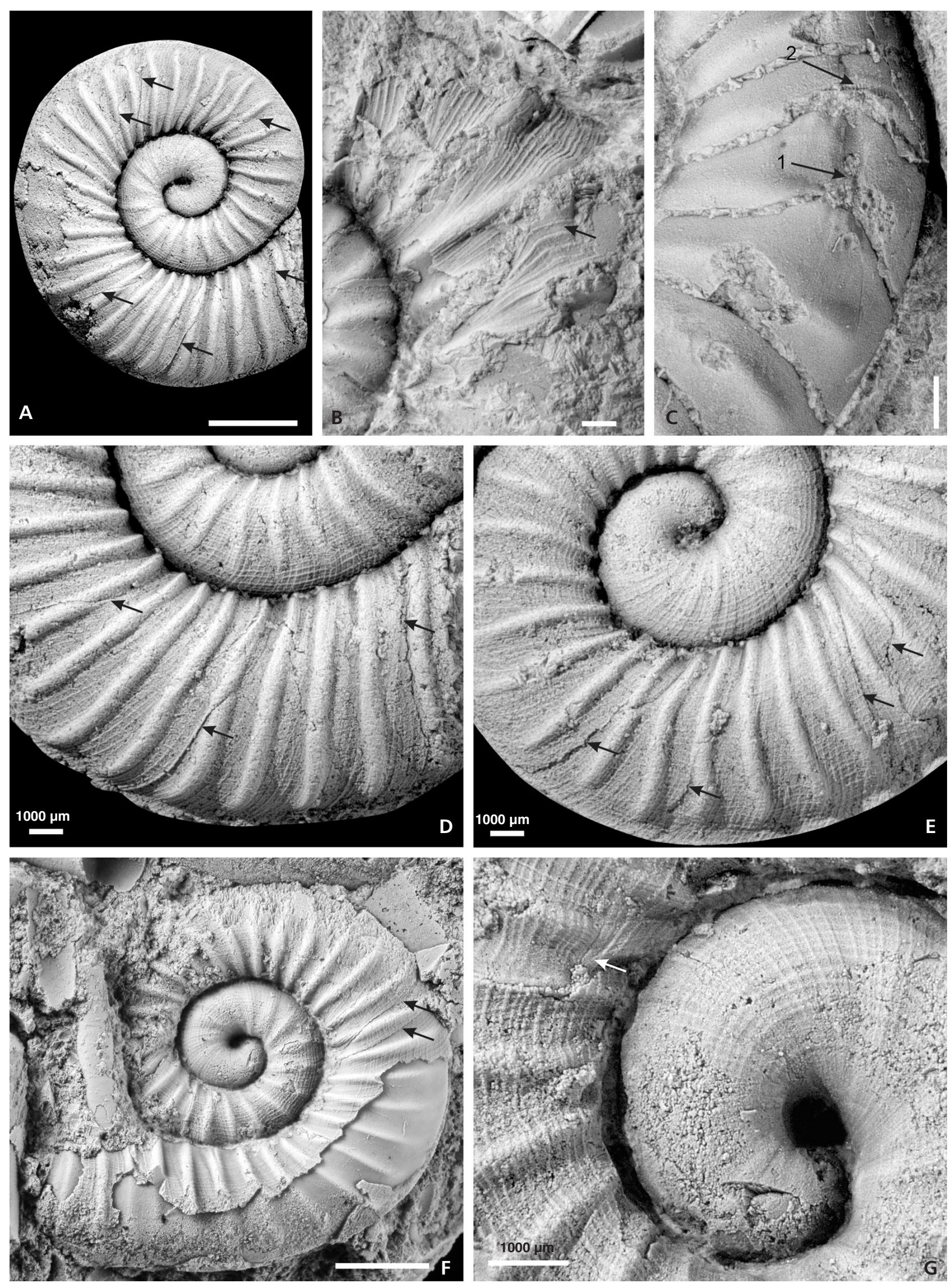
by pits on internal mould, may be caused by predators or by the activity of parasites,

The frequency of pits in Ophioceras is higher than in any other Silurian nautiloid. Unfortunately, we have neither body fossils of parasites/epizoans, nor traces, which could cause these growth anomalies and could be clearly linked to their certain groups.

\section{Autecology and taphonomy}

\section{Palaeogeographic distribution pattern}

Ophioceras inhabited proximal (including reefs) to distal carbonate platforms of Baltica (Gotland, Podoli, Holy Cross Mts, Estonia; Stridsberg \& Turek 1997). The genus is also known from shallow carbonate platforms of Laurentia (Illinois and Wisconsin; Foerste 1925, 1930) and the Yangtze Platform (Chen et al. 1981). Its occurrence is unusual in the slightly deeper fine-grained, siliciclastic deposits of the Anglo-Welsh Basin in Avalonia (Holland 2010). All occurrences coincide with a narrow zone between the equator and $25^{\circ} \mathrm{S}$. The occurrence in the Prague Basin, Perunica microplate, is rather atypical because its palaeogeographical position is still a matter of discussion; its position in the Rheic Ocean to the south of Baltica, however, is widely accepted (Havlíček et al. 1994, Cocks \& Torsvik 2002, Raumer \& Stampfli 2008). In the Prague Basin, Ophioceras inhabited slightly different biotopes than those of tropical carbonate platforms. It is known from shallow water skeletal limestones deposited above fair wave base to cephalopod limestones deposited below wave base; rarely, it has even been found in offshore shales. Sporadically, it has been discovered in platy limestones intercalated with shales and in shales deposited on slopes of isolated archipelagos.

$O$. simplex exhibits a larger dispersion area and is a longer ranging species than $O$. rudens. It documents evolutionary advance of conch with at most $2 \frac{1}{2}$ whorls, instead of the common tarphycerid conch possessing more numerous whorls. The most continuous record of Ophioceras is from Gotland (Wenlock to latest Ludlow) and from the Prague Basin (earlier Ludlow to latest Př́idolí; Stridsberg \& Turek 1997). Ophioceras migrated into other areas only occasionally. Ophioceras migrated into the Prague Basin in the earlier Ludlow, i.e. 6 m.y. after its first appearance in Baltica. O. rudens is known there from the earlier Ludlow (early Gorstian), i.e. from a much shorter interval than in Gotland. Although Ophioceras survived several extinction events (Irviken, Mulde/Lundgreni, Lau/Kozlowskii events), it became extinct during the last Přídolí Transgrediens Event (which is now known to be younger than originally indicated by King 1993). As the extinction of Discoceras Barrande, 1867 is linked with late Wenlock Mulde/Lundgreni Event (Turek \& Manda, unp. data), Ophioceras remained the single surviving tarphycerid genus for more than $8 \mathrm{~m}$.y. The extinction of Ophioceras was most probably connected with the retreat of tropical seas in Laurasia due to the Caledonian Orogeny and with the rise of smaller isolated populations of Ophioceras with higher extinction risk (in Prague Basin and Yangtze Platform).

\section{Autecology of hatchlings}

The data used for this study suggests that small hatchlings of Ophioceras, equipped with only slightly curved conchs possessing one or exceptionally perhaps two phragmocone chambers, differed substantially from adults possessing coiled conchs. Superficially, they resembled the prechambered stage of Nautilus (Mutvei et al. 1993, fig. 10b). Consequently, embryonic development of Ophioceras was rather short. The large volume of the first phragmocone chamber was sufficient to maintain positive buoyancy of hatchlings (Westermann 1998). The very short body chamber limited pulsejet propulsion due to the very low volume of the mantle cavity. Therefore, a planktonic habit of

Figure 18. Pits and other cases of anomalous growth documented on internal moulds of Ophioceras simplex (Barrande, 1855) (A-G, I) and O. rudens Barrande, 1865 (H). A, H - ventral views, B-G, I - lateral views. All specimens from Bohemia. • A - NM-L 31869, Př́idolí, M. transgrediens Zone; probably Karlštejn. Deep pit situated ventrally between carinae in half of body chamber; notice rough surface and fine dots in the bottom and on adapical margin of pit. • B, E- NM-L 28704; Přídolí, M. transgrediens Zone; Karlštejn; three pits in row in middle part of body chamber (arrows 1-3) and deepest pit (2) with relicts of conch in detail (E). $\bullet$ C - NM-L 31919; Ludlow; Beroun-Dlouhá hora; large pit in middle part of body chamber (arrow). D - L 43161; Přídolí, M. transgrediens Zone; Karlštejn. Anomalous course of septa on phragmocone (detail on Fig. 17C) and anomalous development of ribs on body chamber, both linked with laterally situated pits (arrow 1 and 2); another shallow pit located ventrolaterally near aperture (arrow 3); ocular sinus (oc). -F - NM-L 43158; Přídolí, M. transgrediens Zone; Karlštejn. Body chamber with damaged contracted aperture and anomalous growth of ribs; large shallow pit near aperture (arrow 1) and deep small pit situated adapically (arrow 2) in a row with largest one. • G-NM-L 28672, late Ludlow or earlier Přídolí; Praha-Kosoř; Body chamber markedly parasitized. Besides three pits situated laterally in a row, two others are located near the hyponomic sinus, one dextrally (arrow) and another one sinistrally. • H - NM-L 9105; Ludlow, Homerian, N. nilssoni Zone; Praha-Butovice, Na břekvici section. Two of three pits arranged in row situated ventrolaterally (arrows); oldest pit is deepest. • I - NM-L 31865; Př́dolí; probably Karlštejn. Internal mould of adult specimen with two deep laterally situated pits on body chamber, larger with relicts of conch on pit slope; notice also great angle between course of sutures and first ribs on $1^{\text {st }}$ whorl. Scale bars equal $1 \mathrm{~mm}(\mathrm{~A}, \mathrm{E}, \mathrm{H})$ and $5 \mathrm{~mm}(\mathrm{~B}-\mathrm{D}, \mathrm{F}, \mathrm{G}, \mathrm{I})$. 
Vojtěch Turek \& Štěpán Manda • Early ontogeny, anomalous growth, and healed injuries in the Silurian nautiloid Ophioceras
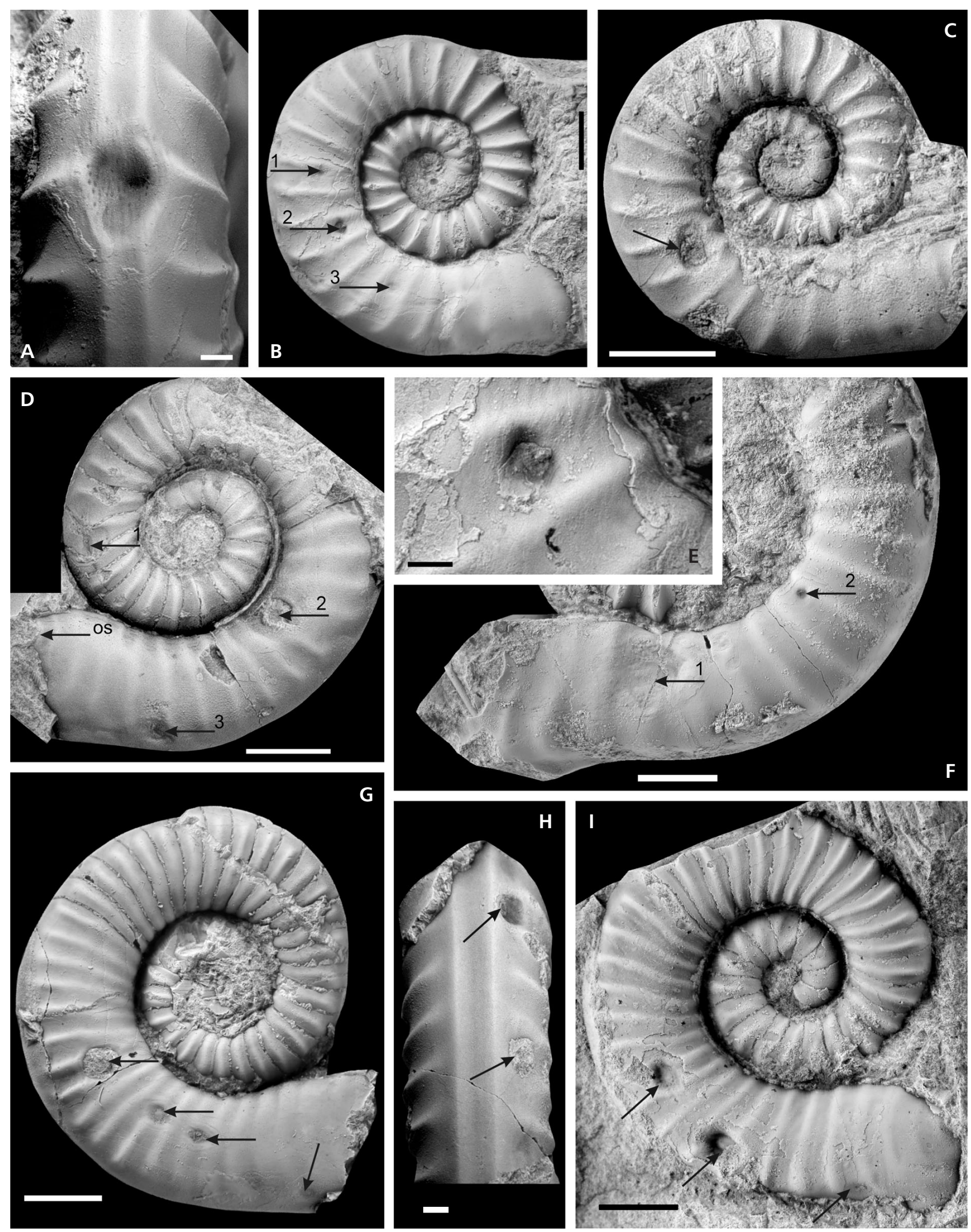
early-hatched specimens is supposed. This is consistent with the conclusion of Holland (1984) and Westermann (1998), who compared early stages of Ophioceras with some ammonoids.

Fossil records of Early Palaeozoic nautiloids with demersal early post-hatching stage consists of co-occurring conchs of all growth stages, although early post-hatching specimens are rather rare and restricted to the part of the area inhabited by adults (e.g. Phragmoceras Broderip in Murchinson, 1939, Manda 2008). No hatchling or juvenile Ophioceras specimens having a shell with less than one and a quarter whorl have been found. The lack of conchs of hatchlings in the fossil record tends to support the assumed planktonic habit of juveniles. The earliest ontogenetic stages of Ophioceras were probably planktonic, and would have been subject to transport by currents in the open sea. By contrast, later nektonic growth stages (Stridsberg \& Turek 1997) usually remained restricted to shallow water domains. Planktonic stages of Ophioceras that died in the open sea were deposited in shale facies, usually under anaerobic or disaerobic conditions, and in such sediments, their primarily aragonite cephalopod conchs were completely dissolved (Turek 1983, 1987; Cherns et al. 2008, 2011). The potential for preservation of their thin-walled fragile conchs was therefore very low. In addition, early juvenile specimens of Ophioceras could be the prey of a range of predators, particularly other cephalopods and phyllocarids, and their conchs could have been crushed due to the activity of these predators and scavengers. Missing fragile hatchlings and early juvenile conchs may also be linked with a taphonomic bias; perhaps, destruction of the conchs during post-mortem transport. It is obvious that small conchs of nautiloids are generally rather rare in comparison with large solid conchs in the fossil record.

Conch growth after hatching and before reaching the first whorl was perhaps relatively fast. It is indicated by widely spaced growth lines. Rapid growth of the conch was possibly accompanied by the further development of soft parts. The hyponomic sinus appeared ventrally early after hatching and soon became deeper; halfway through the first whorl, it was already well developed (Figs 10, 15B), which implies their ability to swim actively with an improved maneuverability. A fully developed hyponomic sinus appeared in conchs reaching one whorl. The appearance of ribs at about a half of the first whorl (exceptionally earlier) led perhaps to substantial reinforcement of the conch. The conch was further strengthened especially after reaching one whorl, when the second whorl came into close contact with the initial whorl. Thus it appears like the early-hatched pelagic stage rapidly changed its mode of life by forming a coiled conch and consequently, the time available for dispersion of the pelagic stage was limited. Rare conch malformations due to injuries during the early stages of development of these organisms may indicate lower predation pressure in the water column than close to the bottom.

\section{Autecology of specimens reaching coiled conch stage}

Adult Nautilus has a moderately deep and wide hyponomic sinus, corresponding to a well-developed hyponome. However, the hyponome appears early in organogenesis still in the egg-capsule, so juvenile specimens have a welldeveloped hyponome. This made active swimming immediately after hatching possible (Arnold et al. 1987, Mutvei et al. 1993) despite the fact that the hyponomic sinus is only weakly developed. Similarly, fossil cephalopods with shallow hyponomic sinus might have been equipped with a hyponome, enabling efficient backward movement. Depth of the hyponomic sinus probably indicates maneuverability of the animal (Westermann 1998). For nautiloids with narrow or strongly constricted apertures as in Ophioceras, a deep hyponomic sinus was a necessary condition to swim actively. If we suppose the same mode of swimming for Ophioceras as in recent Nautilus, a backward movement of the body within the conch by means of powerful retractor muscles caused a substantial reduction of mantle cavity volume. Water was thus quickly propelled from the hyponome. This is not a problem in Nautilus with its open aperture and body extending out of of the conch margin. However, the body of an adult Ophioceras was almost completely enclosed within the conch. Therefore, during the contraction of retractor muscles, the hyponome still had to protrude from the conch.

To approach potential prey, Nautilus spreads its tentacles forward and swims backward. When closing in on the prey, the animal bends the hyponome backward and swims forward to capture the prey (Arnold et al. 1987). Its musculature enables bending of hyponome to any side (Bizikov 2008). The same behavior is proposed for Ophioceras. A narrow and very deep hyponomic sinus enabled bending of the hyponome and swimming forward, quickly leaving the bottom, or escape to any side. As noted above, serious sublethal injuries have been found in conchs of Ophioceras only rarely. Consequently, attacks of predators on Ophioceras were likely either infrequent or lethal. Morphology of the injuries, which are usually V-shaped bites, suggests that these healed injuries may have been caused by other cephalopods or phyllocarids (Signor \& Brett 1884, Brettt 2003, Kröger 2004).

Orientation of the aperture toward the sea floor changed during ontogeny (Stridsberg \& Turek 1997). In not yet fully-grown specimens with an evolute conch, the aperture was oriented forward, as in present day Nautilus. In mature specimens, probably in connection with enlarged gonads, the body chamber length increased. The conch 
became straight and sometimes developed a slight endogastric curvature. The body chamber was directed forward, moderately inclined toward the bottom, which provides better access to the sea floor (Flower 1955, 1957; Stridsberg \& Turek 1997; Manda \& Turek 2009a, 2011). A prominent and deep ocular sinus indicates that the eyes played an important role when searching for food, and was probably higher than in Nautilus. Well-lit shallow sea floors were densely populated by bottom dwellers and demersal predators. Some of them could pose a danger to Ophioceras, which is a rather small nautiloid. A constriction of the aperture in fully grown specimens of Ophioceras thus likely served as protection against attack by predators such as other cephalopods and phyllocarids, as well as yet unknown parasites/epizoans that infested premature specimens. Well-developed ribs, which gave substantial reinforcement to the conch, commonly disappeared close to the contracted aperture.

\section{Phenotypic variability in sculpture: response to environmental conditions?}

In $O$. simplex, the relation of sculpture to rock facies is documented (Stridsberg \& Turek 1997). The most distinctly elaborated reticulate sculpture is present in specimens from very shallow facies, represented especially by light grey skeletal limestone, deposited close to fair wave base. In specimens preserved in black-grey cephalopod limestone and platy limestones (deposited in middle-lower slope below fair wave base), longitudinal ridges are frequently barely visible.

The difference in sculpture in conchs from shallow and deeper water settings documents partial limited migrations between populations of Ophioceras, a feature known so far only from Early Devonian oncocerid Ptenoceras Hyatt, 1894 (Manda \& Turek 2011). A more prominent fine sculpture may be a phenotypic reaction to living in a more turbulent shallow-water domain. Specimens with highly elaborate sculpture occur in skeletal grainstone that was deposited very close to the sedimentation site of a crinoidal sub-tidal limestone. This limestone formed the shore of a volcanic island (e.g. Beroun-Dlouhá hora, U lanovky; Manda \& Kříž 2006). Although we have suggested that adult specimens of Ophioceras were able to actively swim, the sculpture variability and relation of sculpture to rock facies indicate some territoriality, and preference of individuals to certain niches.

\section{Conclusions}

Superficially, hatchlings of Ophioceras resembled the pre-chambered stage of Nautilus (Mutvei et al. 1993, fig. 10b). We suggest that the embryonic conch attained only about a quarter of a whorl and embryonic development was rather short. The curved cap-like conch contained the initial phragmocone chamber; in the rare cases of a very short first chamber, perhaps two phragmocone chambers were developed. The body chamber was very low ventrally due to the oblique course of the first suture. The cicatrix, observed for the first time in tarphycerids, was long and narrow (Fig. 4). The surface of the embryonic conch was ornamented by fine densely spaced growth lines (lirae) or smooth. A cancelate sculpture is sometimes present in the adapertural region. Hatching is usually indicated by the appearance of more widely spaced growth lines on the conch surface. Exceptionally, a dorsolateral groove may also be displayed, analogous to the nepionic constriction in Nautilus. The ribs appear on the conch a little later, usually at the midpoint of the first whorl, and fully developed ribs are present close to the end of the first whorl. No correlation between the diameter of early juvenile conchs (measured at a half of the first whorl) and diameters of the conchs of adult specimen has been found (Tables 1, 2).

Freshly hatched specimens of Ophioceras were probably part of the macro-plankton, and could float in the open sea. Due to limited capacity of the mantle cavity, active swimming abilities of juveniles were minimal. Later stages with coiled-conchs were probably nektonic and probably lived in the lower water column feeding close to the sea floor in a shallow-water environment. Dispersion patterns and sculpture development indicate at least partial territoriality. A deep hyponomic sinus suggests high maneuverability of adults; prominent ocular sinuses indicate well-developed eyes. The straight, obliquely forward protruding adapertural part of the adult conch enhanced access to sea floor, and was a useful adaptation for a demersal habit but reduced swimming abilities.

Sublethal injuries of the conch have been found immediately at the end of the first quarter whorl, i.e. just after suggested hatching. A strikingly anomalous conch sculpture, including minor damage, has been found in the second half of the first whorl. Serious damage to the conch by predators (speculatively by other cephalopods, corypterids or phyllocarids) later in ontogeny is rather rare. It probably reflects high durability of the Ophioceras conch, which was more predation resistant due to strong ribbing. However, the frequency of healed injuries in premature stages is difficult to objectively analyze, since exfoliation of the conch from body chambers during collecting is a common occurrence.

Pits occurring occasionally on Ophioceras conchs are interpreted as the animal's reaction to a parasite/epizoan infestation, which caused anomalous growth of ribs and septa. Some pits may correspond to blister pearls but the relationship of these pits to blister pearls is not certain due to 
absence of intact shell material in the pits. This is one of the few known examples of parasite infestation in Early Palaeozoic nautiloids (Teichert 1964, De Baets et al. 2014).

Sudden decrease of the length of the $7^{\text {th }}, 8^{\text {th }}$ or $9^{\text {th }}$ (Fig. 14) phragmocone chamber occurred rather regularly in Ophioceras. The reduction of phragmocone chamber lengths frequently occurs before reaching the first whorl (see also published data in other tarpycerids and early nautilids; Stumbur 1960, Schimansky \& Zhuravleva 1961). Changing septal spacing could be explained not as a change of the conch shape, but descent of the juveniles to a new habit, and full development of ribs, requiring increasing consumption of calcium carbonate for their secretion. On the basis of the data collected so far, we have not found any support for the presumption that the first distinct change in septal spacing reflects hatching in Ophioceras and other tarphycerids.

The origin of the monogeneric family Ophioceratidae is not clear, but a striking morphological resemblance between this family and Lituitidae Phillips, 1848 (Dzik 1984 , p. 140) is supposed as an example of adaptive convergence (Stridsberg \& Turek 1997). The morphology of the embryonic conch of Ophioceras is very similar to the embryonic conch in species grouped in the family Trocholitidae Chapman, 1857 (Lower Ordovician and early Silurian), namely Curtoceras Ulrich et al., 1942 and Trocholites Conrad, 1838.

Changes of life strategies during ontogeny are distinct features of some Early Palaeozoic nautiloids belonging to many different evolutionary pathways. They initiated competitive interactions unknown in post-Palaeozoic nautilids. Changes in mode of life enabled the occupation of different niches during life, and effective utilization of food sources. By contrast, such autecological changes increased competition pressure (competition of early pelagic stages with pelagic orthocerids and demersal adults with other demersal nautiloids). Nevertheless, there appeared many solutions to these problems, which resulted in the high disparity of Early Palaeozoic nautiloids. Long-term changes in marine faunas during the Triassic and later (e.g., increasing concurrence in demersal niches, increasing diversity of nektonic organisms, abundance of predators; see Signor \& Brett 1984, Brett 2003, Barskov et al. 2008, Klug et al. 2009) selected for nautilids with Nautilus-like habit, i.e. similar habits of hatchlings to adults.

\section{Acknowledgements}

The research was supported by the Ministry of Culture project DKRWO 2015/05 (VT) and the Strategic Research Plan of the Czech Geological Survey and the Czech Grant Agency
205/09/0703 (ŠM). The authors thank J. Bergström†, C. Franzen and J. Hagström (Naturhistoriska riksmuseet Stockholm, Sweden), S. Stridsberg (University of Lund, Sweden) for access to the collection, and their kind assistance during our stay in their institutions. R. Parsley (Tulane University, New Orleans), Petr Daneš (Prague) are acknowledged for reading the manuscript and improving the English, and both reviewers D. Evans (Natural England, Peterborough), B. Kröger (University of Helsinki, Helsinky), and especially C. Klug (University of Zürich) for valuable comments, K. De Baets (Friedrich-Alexander Universität Erlangen) for fruitful discussion concerning pits and pearls in cephalopods. For technical help, especially during photographing, the authors thank L. Váchová, for help during finishing illustrations we thank to J. Sklenáŕ; B. Ekrt for making SEM photo (all National Museum, Prague).

\section{References}

Angelin, N.P. \& Lindström, G. 1880. Fragmenta silurica e dono Caroli Henrici Wegelin. 60 pp. Samson \& Wallin, Holmiae.

ARNold, J.M. 1987. Reproduction and embryology of Nautilus, 353-372. In SAunders, W.B. \& LANDMAN, N.H.E. (eds) Nautilus. The biology and paleobiology of a living fossil. $632 \mathrm{pp}$. Springer, Dordrecht, Heidelberg, London, New York.

Arnold, J.M., Landman, N.H. \& Mutvei, H. 1987. Development of the embryonic shell of Nautilus, 373-400. In SAUnders, W.B. \& Landman, N.H.E. (eds) Nautilus. The biology and paleobiology of a living fossil. 632 pp. Springer, Dordrecht, Heidelberg, London, New York.

Balashov, Z.G. 1962. Ordovician nautiloids from the Siberian platform. 205 pp. Leningrad University Press, Leningrad. [in Russian with English abstract]

BARRANDE, J. 1855. Sur Ascoceras, prototype des Nautilids. Bulletin de la Société géologique de France, $2^{e}$ série 12, 157-177.

BARRANDE, J. 1865. Systême silurien du centre de la Bohême, I. ère partie: Recherches paléontologiques, vol. II, Classe de Mollusques, Ordre des Céphalopodes, ser. 6, pls 1-107. Privately published, Prague $\&$ Paris.

BARRANDE, J. 1867. Systême silurien du centre de la Bohême, I. ère partie: Recherches paléontologiques, vol. II, Classe de Mollusques, Ordre des Céphalopodes, ser. 1. 712 pp. Privately published, Prague $\&$ Paris.

BARRANDE, J. 1868. Systême silurien du centre de la Bohême, I. ère partie: Recherches paléontologiques, vol. II, Classe de Mollusques, Ordre des Céphalopodes, ser. 8, pls 245-350. Privately published, Prague \& Paris.

BARRANDE, J. 1877a. Systême silurien du centre de la Bohême, I. ère partie: Recherches paléontologiques, vol. II, Classe de Mollusques, Ordre des Céphalopodes, ser. 4. supplement, pls 461-544. Privately published, Prague \& Paris.

BARRANDE, J. 1877b. Systême silurien du centre de la Bohême, I. ère partie: Recherches paléontologiques, vol. II, Classe de Mollusques, Ordre des Céphalopodes, ser. 4, 742 pp. Privately published, Prague $\&$ Paris. 
BARskov, I.C. 1989. Morphogeny and ecology of Palaeozoic cephalopods. 160 pp. Izdatelstvo Moskovskogo universiteta, Moscow. [in Russian]

Barskov, I.C., Boiko, M.S., Konovalova, V.A., Leonova, T.B. \& NikolajeVa, S.V. 2008. Cephalopods in the marine ecosystems of the Paleozoic. Paleontological Journal 42, 1167-1284. DOI 10.1134/S0031030108110014

BızıKov, V.A. 2008. Evolution of the shell in Cephalopoda. 444 pp. VNIRO Publishing, Moscow.

BRETT, C.E. 2003. Durophagous predation on Paleozoic marine benthic assemblages, 401-432. In Kelley, P.H., KowALEwsKI, M. \& HANSEn, T. (eds) Predator-prey interactions in the fossil record. 484 pp. Kluwer Academic and Plenum Publishers, New York.

Chamberlain, J.A. \& Pillsbury, S.W. 1985. Fluid transport properties of Nautilus siphuncular tube: within-camera distribution of flow rate. Palaeontology 28, 121-131.

Chapman, E.J. 1857. On the occurrence of the genus Cryptoceras in Silurian rocks. Canadian Journal, New series 2, 264-268.

Chen, J.-Y., Liu, G.-W. \& ChEN, T.-E. 1981. Silurian nautiloid faunas of central and southwestern China. Memoirs of the Nanjing Institute of Geology and Palaeontology 13, 1-104. [in Chinese with English summary]

Cherns, L., Wheeley, J. \& Wright, V. 2008. Taphonomic windows and molluscan preservation. Palaeogeography, Palaeoclimatology, Palaeoecology 270, 220-229. DOI 10.1016/j.palaeo.2008.07.012

Cherns, L., WheEley, J. \& Wright, V. 2011. Taphonomic bias in shelly faunas through time: early aragonitic dissolution and its implications for the fossil record. Topics in Geobiology 32, 79-105. DOI 10.1007/978-90-481-8643-3_3

Chirat, R. 2001. Anomalies of embryonic shell growth in post-Triassic Nautilida. Paleobiology 27, 485-499. DOI 10.1666/0094-8373(2001)027<0485:AOESGI>2.0.CO;2

Chirat, R., Enay, R., HanzPergue, P. \& Mangold, C. 2008. Developmental integration related to buoyancy control in nautiloids: evidence from unusual septal approximation and ontogenetic allometries in a Jurassic species. Palaeontology 51, 251-261.

ChiRAt, R. \& Rioult, M. 1998. Occurrence of early post-hatching Jurassic Nautilida in Normandy, France: palaeobiologic palaeoecologic and palaeobiogeographic implications. Lethaia 31, 137-148.

DOI 10.1111/j.1502-3931.1998.tb00500.x

Chlupáč, I. \& Turek, V. 1983. Devonian goniatites from the Barrandian area, Czechoslovakia. Rozpravy Ústředního ústavu geologického 46, 1-159. DOI 10.1111/j.1475-4983.2007.00734.x

Cocks, L.R.M. \& ToRsviK, T.H. 2002. Earth geography form 500 to 400 million years ago: A faunal and palaeomagnetic review. Journal of the Geological Society, London 159, 631-644. DOI 10.1144/0016-764901-118

ConRad, T.A. 1838. Report on the Palaeontological Department of the Survey (New York). New York State Geological Survey, Annual Report 2, 107-119.

De Baets, K., Klug, C. \& Korn, D. 2011. Devonian pearls and ammonoid-endoparasite coevolution. Acta Palaeontologica Polonica 56, 159-180.

De Baets, K., Landman, N. H. \& Tanabe, K. 2015. Ammonoid embryonic development, 113-205. In KLug, C., Korn, D., DE Baets, K., Kruta, I. \& Mapes, R. (eds) Ammonoid paleobiology: From anatomy to ecology. 934 pp. Springer, Dordrecht, Heidelberg, London, New York.

DziK, J. 1984. Phylogeny of the Nautiloidea. Paleontologia Polonica 45, 1-155.

DziK, J. \& Korn, D. 1992. Devonian ancestors of Nautilus. Paläontologische Zeitschrift 66, 81-98.

DOI 10.1007/BF02989479

EichleR, R. \& Ristedt, H. 1966. Untersuchungen zur Frühontogenie von Nautilus pompilius (Linne). Paläontologische Zeitschrift 40, 173-191. DOI 10.1007/BF02988169

Eichwald, E. 1840. Ueber das silurische Schichtensystem in Esthland. Zeitschrift für Natur- und Heilkunde Medizinische Akademie zu St. Petersburg 1/2, 1-210.

ERBEN, H.K. 1962. Über die „forme elliptique“ der primitive Ammonoidea. Paläontologische Zeitschrift 36, 38-44. DOI 10.1007/BF02987890

Flower, R.H. 1942. An arctic cephalopod faunule from the Cynthiana of Kentucky. Bulletins of American Paleontology $27,1-41$.

FLower, R.H. 1955. Saltations in nautiloid coiling. Evolution 9, 244-260. DOI 10.2307/2405647

Flower, R.H. 1957. Nautiloids of the Paleozoic. Memoirs of the Geological Society of America 67, 829-852. DOI 10.1130/MEM67V2-p829

FLOwER, R.H. 1964. Nautiloid shell morphology. State Bureau of Mines and Mineral Resources, New Mexico Institute of Mining and Technology, Campus Station 13, 1-79.

Flower, R.H. \& Kummel, B. 1950. A classification of the Nautiloidea. Journal of Paleontology 24, 604-616.

Flower, R.H. \& Teichert, C. 1957. The cephalopod order Discosorida. University of Kansas Paleontological Contributions, Mollusca 6, 1-144.

FoERSTE, A.F. 1925. Notes on cephalopod genera; chiefly coiled Silurian forms. Bulletin Denison University, Journal of the Scientific Laboratories 21, 1-69.

Foerste, A.F. 1930. Port Byron and other Silurian cephalopods. Denison University Bulletin, Journal of the Scientific Laboratories 23, 1-110.

Foerste, A.F. \& Savage, T.E. 1927. Ordovician and Silurian cephalopods of the Hudson Bay area. Bulletin Denision University, Journal of the Scientific Laboratories 22, 1-107.

Frank, J., Wilmsen, M. \& KošTÁK, M. 2013. The endemic and morphologically remarkable nautilid genus Deltocymatoceras Kummel, 1956 from the Late Cretaceous of Central Europe. Bulletin of Geosciences 88, 793-812.

DOI 10.3140/bull.geosci.1402

FuRnISH, W.M. \& GLENISTER, B.F. 1964. Nautiloidea-Tarphycerida, 343-368. In Moore, R.C. (ed.) Treatise on invertebrate paleontology, part K, Mollusca 3. 519 pp. Geological Society of America \& University of Kansas Press, Boulder \& Lawrence.

Graus, R.R. 1974. Latitudinal trends in the shell characteristic of 
marine gastropods. Lethaia 7, 303-314.

DOI 10.1111/j.1502-3931.1974.tb00906.x

HaVlíčeK, V., VANĚK, J. \& FAtKa, O. 1994. Perunica microcontinent in the Ordovician (its position within the Mediterranean Province, series division, benthic and pelagic associations). Sborník geologických věd, Geologie 46, 23-56.

Holland, C.H. 1984. Form and function in Silurian cephalopoda. Special Papers in Palaeontology 32, 151-164.

Holland, C.H. 2010. Coiled nautiloid cephalopods from the British Silurian. Proceedings of the Geologists' Association 121, 13-23. DOI 10.1016/j.pgeola.2010.01.004

Holm, G. 1885. Über die innere Organisation einiger silurischer Cephalopoden. Palaeontologische Abhandlungen 3, 1-27.

House, M.R. 1960. Abnormal growth in some Devonian goniatites. Palaeontology 3, 129-136.

Hyatt, A. 1884. Genera of fossil cephalopods. Proceedings of the Boston Society of Natural History 22, 273-338.

Hyatт, A. 1894. Phylogeny of an acquired characteristic. Proceedings American Philosophical Society 32, 349-647. DOI 10.5962/bhl.title.59826

Hyatт, A. 1900. Cephalopoda, 502-592. In Zittel, K.A. \& Eastmann, C.R. (eds) Textbook of Palaeontology, vol. 1. Boston.

Keupp, H. 2012. Atlas zur Paläopathologie der Cephalopoden. Berliner paläobiologische Abhandlungen 12, 1-392.

KING, A.H. 1993. Mollusca: Cephalopoda (Nautiloidea), 169-188. In Benton, M.J. (ed.) The fossil record 2.845 pp. Chapman \& Hall, London.

KLug, C. 2007. Sublethal injuries in Early Devonian cephalopod shells from Morocco. Acta Palaeontologica Polonica 52, 749-759.

Klug, C., Kröger, B., Kiessling, W., Mullins, G.L., Servais, T., FrÝDA, J., Korn, D. \& Turner, S. 2009. The Devonian nekton revolution. Lethaia 43, 465-477. DOI 10.1111/j.1502-3931.2009.00206.x

KŘiž, J. 1992. Silurian field excursions: Prague Basin (Barrandian), Bohemia. National Museum of Wales, Geologica Series 13, 1-111.

KŘ́ǐ, J., JAEGER, H., PARIS, F. \& SchÖNLAUB, H.P. 1986. Přídolí the fourth subdivision of the Silurian. Jahrbuch der Geologischen Bundesanstalt 129, 291-360.

KRÖGER, B. 2003. The size of siphuncle in cephalopod evolution. Senckenbergiana lethaea 83, 39-52.

KRÖGER, B. 2004. Large shell injuries in Middle Ordovician Orthocerida (Nautiloidea, Cephalopoda). GFF 126, 311-316. DOI 10.1080/11035890401263311

KRÖGER, B. 2005. Adaptive evolution in Paleozoic coiled cephalopods. Paleobiology 31, 253-268. DOI 10.1666/0094-8373(2005)031[0253:AEIPCC]2.0.CO;2

KRÖGER, B. 2007. Concentrations of juvenile and small adult cephalopods in the Hirnantian cherts (Late Ordovician) of Porkuni, Estonia. Acta Palaeontologica Polonica 52, 591-608.

KRÖGER, B. \& LANDing, E. 2008. Onset of the Ordovician radiation - evidence from the Rochdale Formation (middle early Ordovician, Stairsian) in eastern New York. Geological Magazine 145, 1-31. DOI 10.1017/S0016756808004585
LANDMAN, N.H. \& Cochran, J.K. 1987. Growth and longevity of Nautilus, 401-420. In Saunders, W.B. \& Landman, N.H. (eds) Nautilus. The biology and paleobiology of a living fossil. 632 pp. Springer, Dordrecht, Heidelberg, London, New York.

Landman, N.H., Rye, D.M. \& Shelton, K.L. 1983. Ontogeny of Eutrephoceras compared to Recent Nautilus and Mesozoic ammonites: evidence for shell morphology and light stable isotopes. Paleobiology 9, 269-279.

Laptichovsky, V.L., Rogov, M.A., NikolaeVa, S.E. \& ARKhiPin, A.I. 2013. Environmental impact on ectocochleate cephalopod reproductive strategies and the evolutionary significance of cephalopod egg size. Bulletin of Geosciences 88, 83-93.

LindSTRÖM, G. 1890. The Ascoceratidae and the Lituitidae of the Upper Silurian formation of Gotland. Kungliga Svenska Vetenskaps-Akademiens Handlingar 23, 1-54.

LAUFELD, S. 1974. Reference localities for palaeontology and geology in the Silurian of Gotland. Sveriges Geologiska Undersokning C705, 1-172.

MANDA, Š. 2008. Palaeoecology and palaeogeographic relations of the Silurian phragmoceratids (Nautiloidea, Cephalopoda) of the Prague Basin (Bohemia). Bulletin of Geosciences 83, 39-62. DOI 10.3140/bull.geosci.2008.01.039

MANDA, Š. \& FRÝDA, J. 2010. Silurian-Devonian boundary events and their influence on cephalopod evolution: evolutionary significance of cephalopod egg size during mass extinctions. Bulletin of Geosciences 85, 513-540. DOI 10.3140/bull.geosci.1174

MANDA, Š. \& KŘiž, J. 2006. Environmental and biotic changes of the subtropical isolated carbonate platforms during Kozlowskii and Lau events (Prague Basin, Silurian, Ludlow). GFF 128, 161-168. DOI 10.1080/11035890601282161

Manda, Š. \& KŘíž, J. 2007. New cephalopod limestone horizon in the Ludlow (Gorstian, early L. scanicus Zone) of the Prague Basin (Bohemia, Perunica). Bollettino della Società Paleontologica Italiana 46, 33-45.

Manda, Š., Štorch, P., Slavík, L., FrÝda, J., Kříž, J. \& TasáRYOVÁ, Z. 2012. The graptolite, conodont and sedimentary record through the late Ludlow Kozlowskii Event (Silurian) in the shale-dominated succession of Bohemia. Geological Magazine 149, 507-534. DOI 10.1017/S0016756811000847

Manda, Š. \& TuReK, V. 2009a. Revision of Pragian Rutoceratoidea Hyatt, 1884 (Nautiloida, Oncocerida) from the Prague Basin. Bulletin of Geosciences 84, 127-148. DOI 10.3140/bull.geosci.1118

MANDA, Š. \& TUREK, V. 2009b. Minute Silurian oncocerid nautiloids with unusual colour patterns. Acta Palaeontologica Polonica 54, 503-512. DOI 10.4202/app.2008.0062

Manda, Š. \& Turek, V. 2011. Late Emsian Rutoceratoidea (Nautiloidea) from the Prague Basin, Czech Republic: morphology, diversity and palaecology. Palaeontology 54, 999-1024. DOI 10.1111/j.1475-4983.2011.01089.x

Mapes, R.H. \& Chaffin, D.T. 2003. Predation on cephalopods. A general overview with a case study from the Upper Carboniferous of Texas, 177-213. In Kelley, P.H., Kowalewski, M. \& Hansen, T.A. (eds) Predator-prey interactions in the fossil re- 
cord. 464 pp. Kluwer Academic/Plenum Publishers, New York, Boston, Dordrecht, London, Moscow.

Mapes, R.H., NiKo, S., FrÝdA, J. \& NÜTZEL, A. 2007. A newly hatched coiled nautiloid from the Permian of Italy. Journal of Paleontology 81, 1118-1121. DOI 10.1666/pleo05-144.1

Meyer, H. v. 1831. Beschreibung des Orthoceratites striolatus, und über den Bau und des Vorkommen einiger vielkammerigen fossilen Cephalopoden; nebst der Beschreibung von Calymene aequalis. Nova acta physico-medica Academiae Caesareae Leopoldino-Carolinae Naturae Curiosum 15(2), 57-112.

MiLLER, A.K. 1932. The Michochoanitic cephalopods. University of Iowa Studies in Natural History 14, 15-19.

Mironenko, A.A. in press. A new type of shell malformation caused by epizoans in Late Jurassic ammonites from Central Russia. Acta Palaeontologica Polonica 61.

Morton, S.G. 1833. Synopsis of the organic remains of the ferruginous sand formation of the United States. American Journal of Science 23, 291.

Murchison, R.I. 1839. The Silurian System Founded on Geological Researches in the Counties of Salop, Hereford, Padnor, with Descriptions of the Coal Fields and Overlying Formations. Part 1. 768 pp. London.

Mutver, H. 1957. On the relations of the principal muscles to the shell in Nautilus and some fossil nautiloids. Arkiv for Mineralogi och Geologi 2, 219-254.

MutVeI, H. 2002. Nautiloid systematics based on siphuncular structure and position of muscle scars. Abhandlungen der Geologischen Bundesanstalt 57, 379-392.

Mutvei, H. 2013. Characterization of nautiloid orders Ellesmerocerida, Oncocerida, Tarphycerida, Discosorida and Ascocerida. New Superorder Multiceratoidea. GFF 135, 171-183. DOI 10.1080/11035897.2013.801034

Mutvei, H., Arnold, J.M. \& Landman, N.H. 1993. Muscles and attachment of the body to the shell in embryos and adults of Nautilus balauensis (Cephalopoda). American Museum Novitates 3059, 1-15.

Mutvei, H. \& Doguzhaeva, L.A. 1997. Shell ultrastructure and onto-genetic growth in Nautilus pompilius L. (Mollusca: Cephalopoda). Palaeontographica, Abteilung A 246, 33-52.

Mutvei, H. \& Dunca, E. 2011. Siphuncular structure in the orders Tarphycerida and Barrandeocerida (Cephalopoda: Nautiloidea). Palaeontology 54, 705-710.

DOI 10.1111/j.1475-4983.2011.01041.x

Mutvei, H. \& Weitschat, W. 2010. Siphuncular structure in the Recent Nautilus, compared with that in Mesozoic nautilids and ammonoids from Madagascar. GFF 132, 161-166. DOI 10.1080/11035897.2010.510204

NaEF, A. 1921-28. Die Cephalopoden. Fauna and Flora des Golfes von Neapel, Teil 1 und 2. 864 pp. Friedländer Press, Berlin.

Phillips, J. 1848. The Malvern Hills, Compared with the Palaeozoic Districts of Abberley, Woolhope, May Hill, Tortworth and Usk. Geological Survey of Great Britain Memoir $1 / 2,256-250$.

Raumer, J.F. \& Stampfli, G.M. 2008. The birth of the Rheic
Ocean - Early Palaeozoic subsidence patterns and subsequent tectonic plate scenarios. Tectonophysics 461, 9-20.

DOI 10.1016/j.tecto.2008.04.012

Ruedemann, R. 1904. Cephalopoda of the Beekmantown and Chazy formations of the Champlain Basin. Bulletin New York State Museum 90, 1-605.

SAunders, W.B. \& Landman, N.H.E. (eds) 1987. Nautilus. The biology and paleobiology of a living fossil. $632 \mathrm{pp}$. Springer, Dordrecht, Heidelberg, London, New York.

Schroeder, H. 1891. Untersuchungen über silurische Cephalopoden. Palaeontologische Abhandlungen, Neue Folge 1, $1-48$.

Shimansky, V.N. \& Zhuravleva, F.A. 1961. Fundamental questions of the systematics of the nautiloids and the relationship of this group. Trudy Paleontologitscheskogo instituta Akademii nauk 90, 1-175. [in Russian]

Shindewolf, O.H. 1934. Zur Stammesgeschichte der Cephalopoden. Jahrbuch der Preussischen Geologischen Landesanstalt 55, 258-283.

Signor, P.W. \& BRETT, C.E. 1984. The mid-Paleozoic precursor to the Mesozoic marine revolution. Paleobiology 10, 229-245.

Slotta, F, Korn, D., Klug, C., KröGer, B \& Keupp, H. 2011. Sublethal shell injuries in Late Devonian ammonoids (Cephalopoda) from Kattensiepen (Rhenish Mountains). Neues Jahrbuch für Geologie und Paläontologie, Abhandlungen 261, 321-336. DOI 10.1127/0077-7749/2011/0173

Sobolev, E.S. 1989. Triasic nautilids of northeastern Asia. Trudy Paleontologitscheskogo instituta Akademie nauk 727, 1-192. [in Russian]

Spath, L.F. 1923. A monograph of the Ammonoidea of the Gault, Part 1. Monograph, Palaeontographical Society (London) 75(353), 1-72.

Spath, L.F. 1933. The evolution of the cephalopoda. Biological Reviews 8, 418-462.

DOI 10.1111/j.1469-185X.1933.tb01158.x

Stenzel, H.B. 1964. Living Nautilus, 59-93. In Moore, R.C. (ed.) Treatise on invertebrate paleontology, Part K, Mollusca 3. 519 pp. University of Kansas Press, Lawrence.

StRAnd, T. 1934. The Upper Ordovician Cephalopods of the Oslo Area. Norsk geolog Tidsskrift 14, 1-117.

StridsberG, S. 1985. Silurian oncocerid cephalopods from Gotland. Fossils and Strata 18, 1-165.

Stridsberg, S. \& Turek, V. 1997. A revision of the Silurian nautiloid genus Ophioceras Barrande. GFF 19, 21-36. DOI 10.1080/11035899709546450

Stumbur, H.A. 1959. Embryonic shell of some Ordovician tarphyceratids. Paleontologicheskii zhurnal 2, 25-29. [in Russian]

Stumbur, H.A. 1960. Early development of nautiloids. Izvestia Akademii nauk Estonskoi SSR, Seria fiziko-matematiczeskich i techniczeskich nauk 4, 368-378. [in Russian]

Stumbur, H.A. 1962. Distribution of nautiloids in the Ordovician of Estonia (with description of some new genera). Trudy Instituta geologii Akademii nauk Estonskoi SSR 10, 130-148. [in Russian] 
SweEt, W.C. 1958. The Middle Ordovician of the Oslo region of Norway. 10. Nautiloid cephalopods. Norsk geologisk Tidsskrift 3, 1-178.

SweEt, W.C. 1964. Nautiloidea - Barrandeocerida, 368-389. In Moore, R.C. (ed.) Treatise on invertebrate paleontology, Part K, Mollusca 3, Cephalopoda. 519 pp. Geological Society of America \& University of Kansas Press, Boulder \& Colorado.

Teichert, C. 1964. Morphology of hard parts, 13-53. In Moore, R.C. (ed.) Treatise on invertebrate paleontology, Part K, Mollusca 3.519 pp. Geological Society of America \& University of Kansas Press, Boulder \& Lawrence.

Teichert, C. 1988. Main features of cephalopod evolution, 11-79. In Clarke, M.R. \& Trueman, E.R. (ed.) The Mollusca, vol. 12: Paleontology and Neontology of Cephalopoda. $355 \mathrm{pp}$. Academic Press, Inc. San Diego, New York, Berkeley, Boston, London, Sydney, Tokyo, Toronto.

Turek, V. 1972. On the systematic position of the genus Ophioceras Barrande, 1860. Časopis Národního muzea, $\breve{R} a d a$ přirodovědná 141, 30-32.

TureK, V. 1975. Genus Kosovoceras gen. n. in the Silurian of Central Bohemia (Nautiloidea). Sborník geologických věd, Paleontologie 17, 7-39.

TuREK, V. 1976. Magdoceras gen. n. and Inclytoceras gen. n. from the Silurian of central Bohemia (Nautiloidea, Barrandeoceratida). Casopis pro mineralogii a geologii 21, 137-145.

TuReK, V. 1983. Hydrodynamic conditions and the benthic community of Upper Wenlockian calcareous shale in western part of the Barrandian (Kosov quarry). Časopis pro mineralogii a geologii 28, 245-260.

TuREK, V. 1987. On some epizoans of molluscs shells from the Upper Silurian (Pridolian) of the Barrandian area. Věstník Ústředního ústavu geologického 62, 105-111.

TuREK, V. 2007. Systematic position and variability of the Devonian nautiloid Hercoceras and Ptenoceras from the Prague Basin (Czech Republic). Bulletin of Geosciences 82, 1-10. DOI 10.3140/bull.geosci.2007.01.1

TureK, V. 2008. Boionautilus gen. nov. from the Silurian of Europe and North Africa (Nautiloidea, Tarphycerida). Bulletin of Geosciences 83, 141-152.

DOI 10.3140/bull.geosci.2008.02.141

TuREK, V. 2010. Embryonic shells in some lechritrochoceratids (Nautiloidea, Barrandeocerida), 85-92. In TANABE, K. (ed.)
Cephalopods. Present and Past. 314 pp. Tokai University Press, Tokyo.

TUREK, V. \& MANDA, Š. 2010. Variability of colour pattern and shell malformations in Silurian nautiloid Peismoceras Hyatt, 1884. Journal of the National Museum, Natural History 179, 171-178.

Ulrich, E.O., Foerste, A.F., Miller, A.K. \& Furnish, W.M. 1942. Ozarkian and Canadian Cephalopods Part I: Nautilicones. Geological Society of America Special Papers 37, 1-157. DOI 10.1130/SPE37-p1

VERMEJ, G. 1987. Evolution and escalation, an ecological history of life. 527 pp. Princeton University Press, Princeton, NJ.

Wahlenberg, G. 1821. Petrificata telluris Suecana examinata a Georgio Wahlenberg. Svecanae. Nova Acta Regiae Societatis Scientarium Upsaliensis 8, 1-116.

WANI, R. 2005. New look at ammonoid taphonomy, based on field experiments with modern chambered Nautilus. Geology 33, 849-852. DOI 10.1130/G21712.1

Wani, R., Kurihara, K. \& Ayyasami, K. 2011. Large hatchling size in Cretaceous nautiloids persists across the end-Cretaceous mass extinction: New data of Hercoglossidae hatchlings. Cretaceous Research 32, 618-622.

DOI 10.1016/j.cretres.2011.01.001

Walliser, O.H. 1962. Die Arten der Gattung Gyroceratites Hh. V. Meyer, 1831 (Ammonoidea, Unter- bis Mitteldevon). Neues Jahrbuch für Geologie und Paläontologie, Monatshefte $11,565-576$.

WARD, P.D. 1987. Natural history of Nautilus. 263 pp. Allen and Unwin, Boston.

Westermann, G.E.G. 1998. Life Habits of Nautiloids, 263-298. In SAvazzI, E. (ed.) Functional Morphology of the Invertebrate Skeleton. Wiley, London.

WhitFielD, R.P. 1886. Notice of geological investigations along the eastern shores of Lake Champlain conducted by Prof. H. M. Seely and Prest. Ezra Brainerd, of Middlebury College, with descriptions of new fossils discovered. American $\mathrm{Mu}$ seum of Natural History Bulletin 1, 293-345.

YomogidA, S. \& WANI, R. 2013. Higher risk of fatality by predatory attacks in the earlier ontogenetic stages of modern Nautilus pompilius in the Philippines: evidence from the ontogenetic analyses of shell repairs. Lethaia 46, 317-330. DOI 10.1111/let.12010 